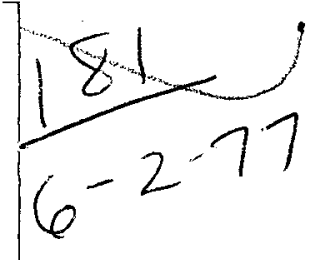

GA-A 14269

UC-77

\title{
STRENGTH TESTING OF PRODUCTION GRADE H-451 GRAPHITE; LOTS 472, 478, AND 482
}

by
G. B. ENGLE and R. J. PRICE

Prepared under

Contract EY-76-C-03-0167

Project Agreement No. 17

for the San Francisco Operations Office

U.S. Energy Research and Development Administration

DATE PUBLISHED: MARCH 1977

MASTER

DISTRIBUTION OF THIS DOCUMENT IS UNLIMITED 


\section{DISCLAIMER}

This report was prepared as an account of work sponsored by an agency of the United States Government. Neither the United States Government nor any agency Thereof, nor any of their employees, makes any warranty, express or implied, or assumes any legal liability or responsibility for the accuracy, completeness, or usefulness of any information, apparatus, product, or process disclosed, or represents that its use would not infringe privately owned rights. Reference herein to any specific commercial product, process, or service by trade name, trademark, manufacturer, or otherwise does not necessarily constitute or imply its endorsement, recommendation, or favoring by the United States Government or any agency thereof. The views and opinions of authors expressed herein do not necessarily state or reflect those of the United States Government or any agency thereof. 


\section{DISCLAIMER}

Portions of this document may be illegible in electronic image products. Images are produced from the best available original document. 
This report was prepared as an account of work sponsored by the United States Government. Neither the United States nor the United States Energy Research and Development Administration, nor any of their employees, nor any of their contractors, subcontractors, or their employees, makes any warranty, express or implied, or assumes any legal liability or responsibility for the accuracy, completeness or usefulness of any information, apparatus, product or process disclosed, or represents that its use would not infringe privately owned rights.

\author{
Printed in the United States of America \\ Available from \\ National Technical Information Service \\ U.S. Department of Commerce \\ 5285 Port Royal Road \\ Springfield, Virginia 22161 \\ Price: Printed Copy $\$ 5.50$; Microfiche $\$ 3.00$
}




\title{
STRENGTH TESTING OF PRODUCTION GRADE H-451 GRAPHITE; LOTS 472, 478, AND 482
}

\author{
by \\ G. B. ENGLE and R. J. PRICE
}

\section{Prepared under
Contract EY-76-C-03-0167
Project Agreement No. 17 \\ Prepared under
Contract EY-76-C-03-0167
Project Agreement No. 17 \\ Prepared under
Contract EY-76-C-03-0167
Project Agreement No. 17 \\ for the San Francisco Operations Office \\ U.S. Energy Research and Development Administration

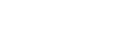
This report was prepared as an account of work
sponwored by the United States Covernment. Neither the United States nor the United States Enersy Research and Development Administration, nor any of their employees, nor any of their contractors, subcontractors, or theit employees, makes any warranty, express of impied, or asumes any ezgi

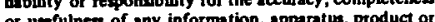
or useniness of any informs tion, apperalus, product or

infringe privately owned rights. 


\section{ABSTRACT}

Ninety-eight production logs of $\mathrm{H}-451$ graphite, from three separate extrusion lots, were sampled for tensile testing. Eight replicate axial specimens from the midlength center and four replicate radial specimens from the end center of each $\log$ were tested. The axial strengths (average value $12.7 \mathrm{MPa}$ ) showed wide lot-to-lot and log-to-log variations, while the radial strengths (average value $15.8 \mathrm{MPa}$ ) were more uniform. Statistically based acceptance criteria which could be used for assigning a log to a minimum strength category were derived for two alternative definitions of "minimum" strength. The first definition would require $90 \%$ of the material at the midlength center of the log to exceed the specified minimum strength, with $90 \%$ confidence (90/90); the second, more stringent, definition would require $99 \%$ of the material to exceed the specified minimum, with $95 \%$ confidence $(99 / 95)$. If three minimum strength categories are assumed, with category A requiring a minimum strength of $10.3 \mathrm{MPa}$, category $B$ requiring $8.3 \mathrm{MPa}$, and category $\mathrm{C}$ requiring $5.5 \mathrm{MPa}$, use of the $90 / 90$ definition of minimum strength would cause the rejection of two logs. Use of the 99/95 definition of minimum strength would increase the number of rejected logs to 18; however, this would include only 2 out of the $56 \operatorname{logs}$ in the best extrusion lot. Decreasing the number of tests per log from eight to four would cause only small differences in the yields of logs accepted in each category. 


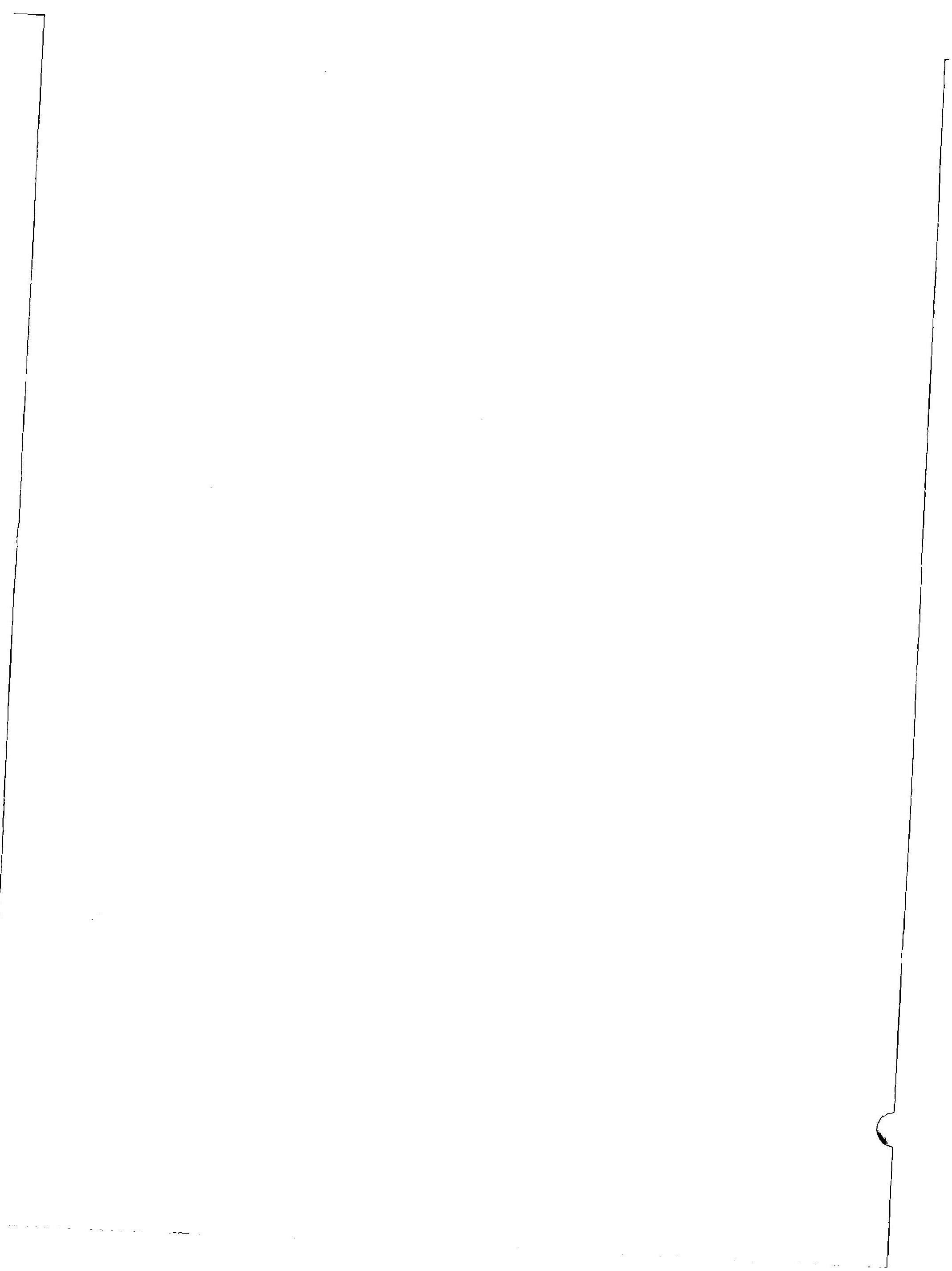


CONTENTS

ABSTRACT . . . . . . . . . . . . . . . . . . . iii

1. SUMMARY AND CONCLUSIONS . . . . . . . . . . . . . . 1

2. INTRODUCTION. . . . . . . . . . . . . . 3

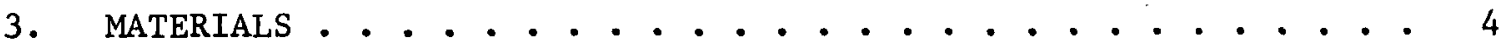

4. EXPERIMENTAL METHODS. . . . . . . . . . . . . . 9

5. EXPERIMENTAL RESULTS. . . . . . . . . . . . . . . 10

5.1. Axial Specimens . . . . . . . . . . . . . 10

5.2. Radial Specimens. . . . . . . . . . . . . 11

6. APPLICATION OF RESUlTS TO ACCEPTANCE TESTING. . . . . . . 14

6.1. Strategy for Acceptance Testing . . . . . . . . . 14

6.2. Statistical Model ............... 14

6.3. Acceptance Criteria . . . . . . . . . . . 15

6.4. Yields of Logs by Category. . . . . . . . . . . . 19

7. ACKNOWLEDGMENTS . . . . . . . . . . . . . . . . 21

8. REFERENCES. . . . . . . . . . . . . . . . . 22

APPENDIX A: IDENTIFICATION NUMBERS AND. DENSITIES OF LOGS IN

EXTRUSION LOTS 472, 478, AND 482 . . . . . . . . A-1

APPENDIX B: AXIAL TENSILE STRENGTH MEASUREMENTS FOR EXTRUSION

LOTS 472, 478, AND 482. . . . . . . . . . . . B-1

APPENDIX C: RADIAL TENSILE STRENGTH MEASUREMENTS FOR EXTRUSION

LOTS 472, 478, AND 482. . . . . . . . . . . . C-1

FIGURES

1. Slabbing and coring H-451 fuel element logs ......... 5

2. Axial tensile strength specimens. . . . . . . . . . 6

3. Radial tensile strength specimens . . . . . . . . . . 7 


\section{TABLES}

1. Statistical analysis of axial strength data. . . . . . . 12

2. Statistical analysis of radial strength data . . . . . . . 12

3. Components of variance: Axial strength data . . . . . . 16

4. Criteria for assigning logs to strength categories $A, B$, or C . . . . . . . . . . . . . . 18

5. Yields of logs in each strength category . . . . . . . . 20

A-1. Identification numbers and densities of logs in extrusion

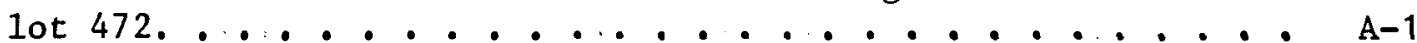

A-2. Identification numbers and densities of logs in extrusion

lot 478.................... . A $\mathrm{A}-2$

A-3. Identification numbers and densities of logs in extrusion

$\log$ 482..................... A-3

B-1. Axial tensile strength measurements: extrusion lot 472. . . . B-1

B-2. Axial tensile strength measurements: extrusion lot 478. . . . B-1

B-3. Axial tensile strength measurements: extrusion lot 482 . . . B-25

B-4. Summary of axial strength data for extrusion lot 472 . . . . B-35

B-5. Summary of axial strength data for extrusion lot 478'. . . B-36

B-6. Summary of axial strength data for extrusion lot 482 . . . . B-37

C-1. Radial tensile strength measurements: extrusion lot 472 . . . C-1

C-2. Radial tensile strength measurements: extrusion lot 478 . . . C-5

C-3. Radial tensile strength measurements: extrusion lot 482 . . C-19

C-4. Summary of radial strength data for extrusion lot 472. . . . C-26

C-5. Summary of radial strength data for extrusion lot 478. . . . . C-27

C-6. Summary of radial strength data for extrusion lot 482. . . . C-28 
1. SUMMARY AND CONCLUSIONS

Ninety-eight production logs of $\mathrm{H}-451$ graphite, from three separate extrusion lots, were sampled for tensile testing. Eight replicate axial specimens from the midlength center and four replicate radial specimens from the end center of each $\log$ were tested. The following observations were made:

1. The axial strengths (average value $12.7 \mathrm{MPa}$ ) showed wide lotto-lot and $\log$-to-log variations, while the radial strengths (average value $15.8 \mathrm{MPa}$ ) were more uniform (see Section 5, Tables 1 and 2).

2. There was no statistically significant correlation between axial strength and radial strength in the same $10 \mathrm{~g}$, or between strength and the position of the $\log$ in the graphitizing furnace.

3. Acceptance criteria for assigning logs to a minimum strength category could be based on axial tensile tests, and each log should be sampled. A statistical model incorporating a separate lot-to-lot variance, log-to-log variance, and within-log variance was adopted for this purpose.

4. Acceptance criteria which could be used for assigning a 1 og to strength category A [minimum strength $10.3 \mathrm{MPa}$ (1500 psi)], B [minimum strength $8.3 \mathrm{MPa}(1200 \mathrm{psi})$ ], or C [minimum strength $5.5 \mathrm{MPa}$ (800 psi)] were derived (see Section 6, Table 4). Calculations were made for either four or eight replicate specimens per $\log$ and two alternative definitions of "minimum strength" were considered. The first definition would require $90 \%$ of the material at the midlength center of the log to 
exceed the specified minimum strength, with $90 \%$ confidence $(90 / 90)$; the second, more stringent, definition would require $99 \%$ of the material to exceed the specified minimum, with $95 \%$ confidence $(99 / 95)$.

5. The criteria were applied to the axial test data from the 98 logs. Using the $90 / 90$ definition of minimum strength and testing eight specimens per $10 \mathrm{~g}$, two logs would fail to qualify for category $C$ while almost half of the logs would qualify for category A.

6. Use of the $99 / 95$ definition of minimum strength would increase the number of $\operatorname{logs}$ rejected to 18 ; the yield of $\operatorname{logs}$ accepted in each strength category would fall slightly short of the requirements of a typical core segment.

7. Decreasing the number of tests per log from eight to four would cause a small reduction in the yields.

8. The differences in quality between the three extrusion lots represented in the 98-log order have a clear effect on the yields of logs in each strength category. Using the $99 / 95$ definition of minimum strength, only two of the 56 logs in the best lot (478) would be rejected and about 25\% would qualify for category A. This compares with a rejection rate of about $40 \%$ for logs from the other two lots. 


\section{INTRODUCTION}

Grade H-451 is under development by the Great Lakes Carbon Corporation (GLCC) as a candidate graphite for Large High-Temperature Gas-Cooled Reactor (LHTGR) replaceable fuel and reflector blocks. Characterization and irradiation data on preproduction grade $\mathrm{H}-451$ were reported in Refs. 1 through 5. This report contains tensile strength data on 98 production logs, which were produced as a portion of 354-log order for. Fort St. Vrain (FSV) reload fuel elements. The strength specimens were taken from locations which would not interfere with subsequent machining operations and were used to assess strategies for acceptance testing of logs from large production orders. 


\section{MATERIALS}

The material consisted of 98 full-size $[431.8 \mathrm{~mm}$ (17 in.) diameter by $812.8 \mathrm{~mm}$ (32 in.) long] production logs. These logs were produced with the same formulation and procedures used to produce preproduction lot 426 (see Ref. 1).

The 98 logs were a portion of a 354-log order for FSV reload fue1 elements. The 354-log order was manufactured through the bake step and then stored due to a delay in the final processing of the order. The 98 logs described in this report were taken through the graphitization step and portions were distributed to General Atomic Company (GA), Oak Ridge National Laboratory (ORNL), and Brookhaven National Laboratory (BNL) for experimental purposes. The 98 logs were taken from three different production extrusion lots (472, 478, and 482), but all logs were graphitized in the same furnace run. The logs were sampled for tensile testing by GLCC at their Morganton Plant in accordance with a sampling plan devised by GA. The GA axial strength specimens were taken as near to the midlength center of each $\log$ as possible [within $51 \mathrm{~mm}$ ( $2 \mathrm{in.}$ ) of the centerline, see Fig. 1] while preserving the logs for subsequent machining into a fuel element. A $16 \mathrm{~mm}$ (0.625 in.) diameter by $356 \mathrm{~mm}$ (14 in.) long rod was cored from the center and a $25 \mathrm{~mm}$ (1 in.) slab was taken from one end of each 1og. A $102 \mathrm{~mm}$ (4 in.) core was taken for axial specimens as shown in Fig. 1. Axial test specimens $6.35 \mathrm{~mm}$ in diameter by $23 \mathrm{~mm}$ long were machined from the axial core as shown in Fig. 2, and radial specimens of the same size were machined from the end slab as shown in Fig. 3. A single tensile test specimen $(12.8 \mathrm{~mm}$ diameter by $76.2 \mathrm{~mm}$ long) was taken from each central core as shown in Fig. 1 for measurement by GLCC.

Eight axial specimens and four radial specimens from each $10 \mathrm{~g}$ were measured for ultimate tensile strength at $\mathrm{GA}$, and one axial specimen from 


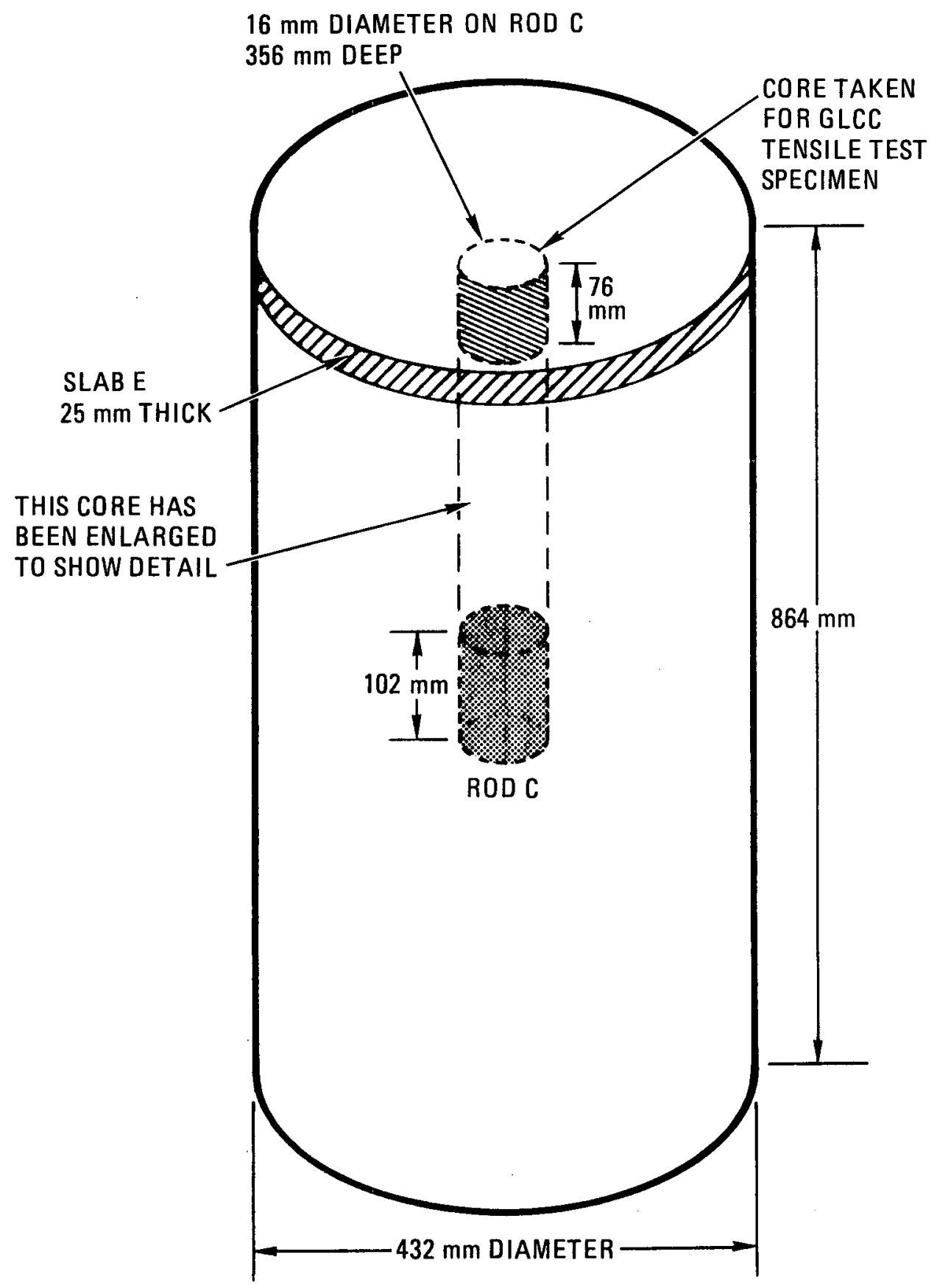

Fig. 1. Slabbing and coring $\mathrm{H}-451$ fuel element logs 
ROD C

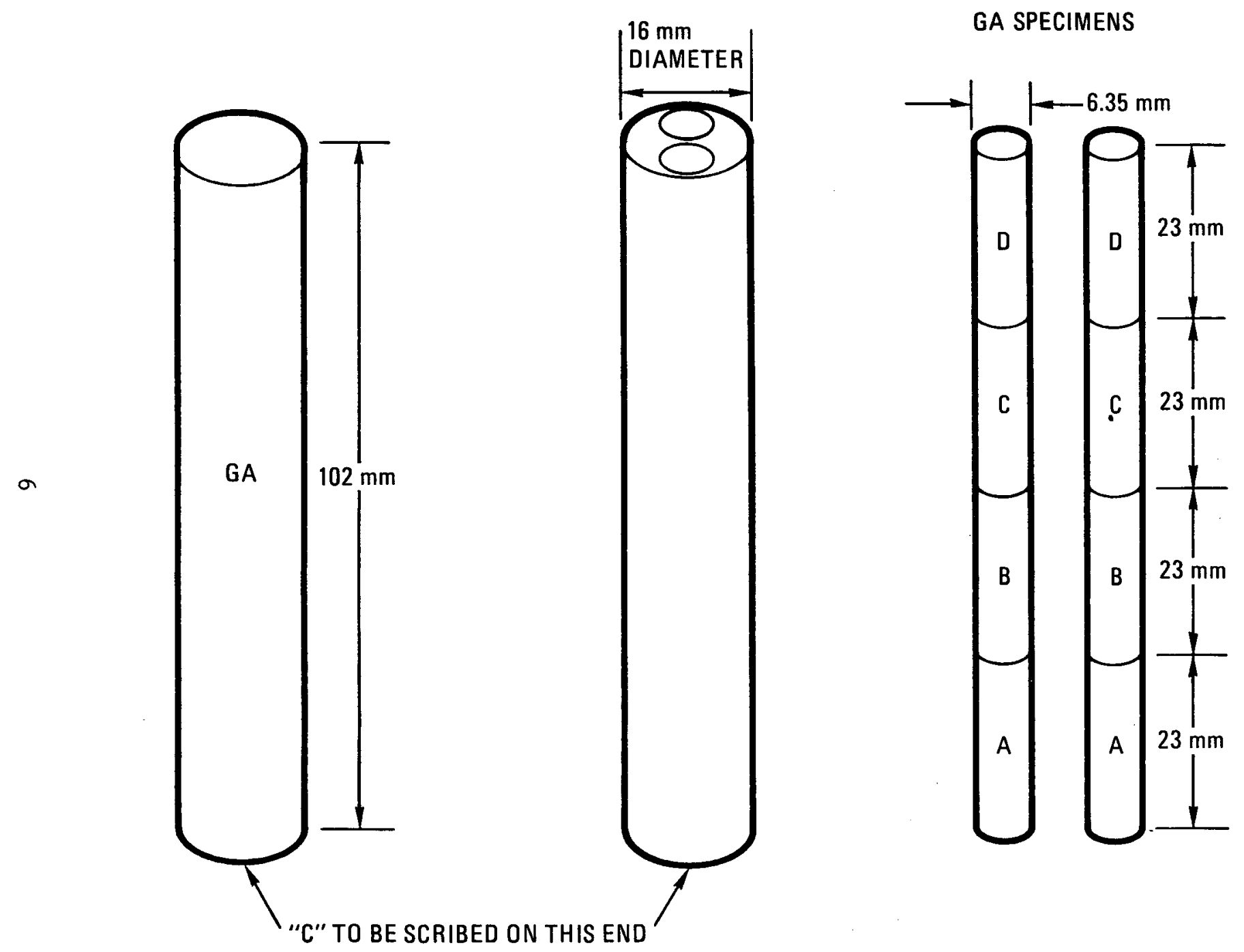

Fig. 2. Axial tensile strength specimens 


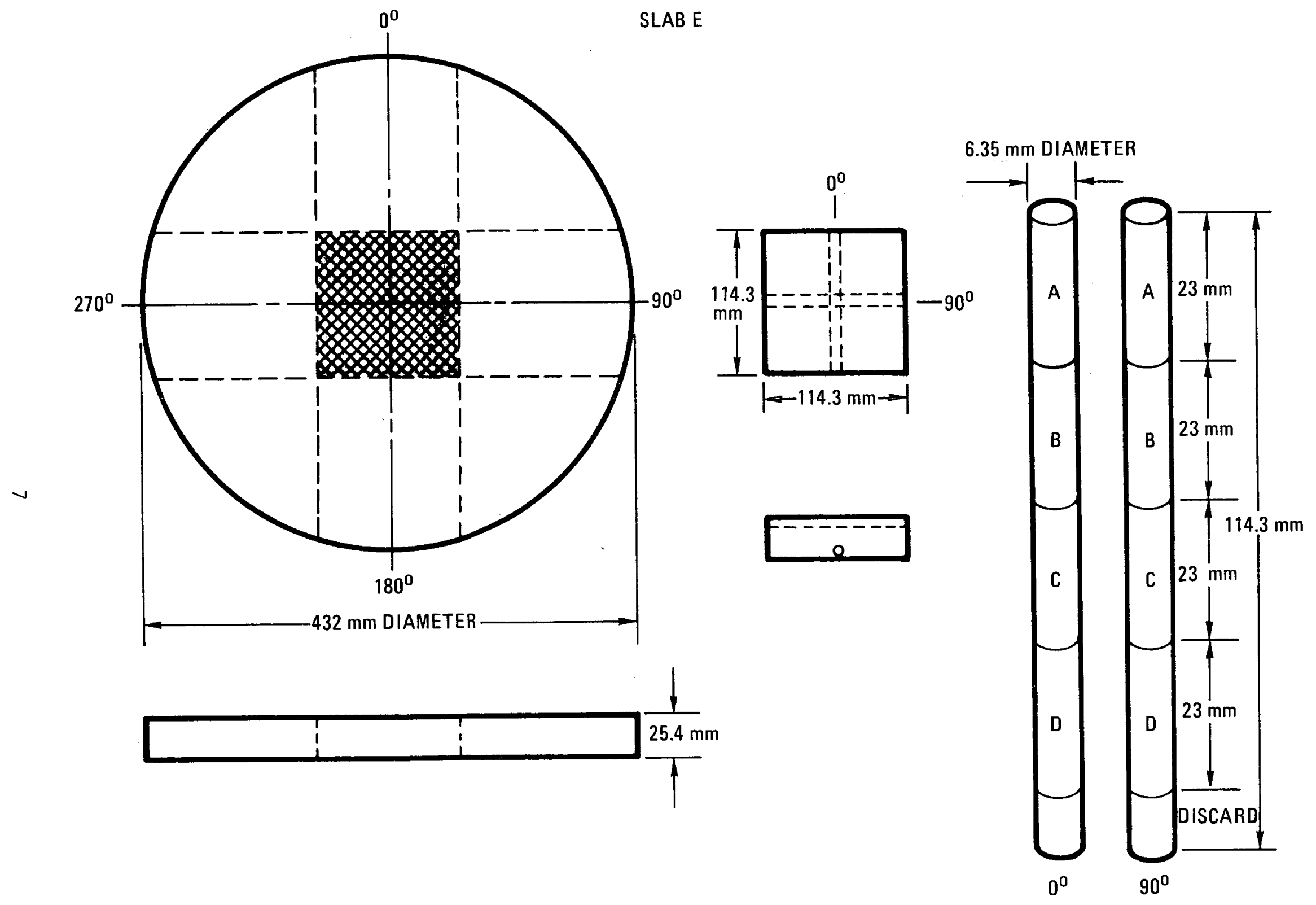

Fig. 3. Radial tensile strength specimens 
each $\log$ was measured at GLCC. The manufacturer's identification numbers, positions in the graphitizing furnace, and the bulk density of each $10 \mathrm{~g}$ are listed for each extrusion lot in Appendix A (Tables A-1 through A-3). The logs are listed in order of furnace position. In this report the identification numbers assigned at GA (first column of Tables A-1 through A-3) are used. 


\section{EXPERIMENTAL METHODS}

The tensile test method is described in Ref. 1. General Atomic and GLCC used the same tensile strength method, although the specimen size differed (Section 3). Round-robin tests performed on controlled specimen sets of H-451 showed the two laboratories to agree within $1 \%$ using the method described in Ref. 1. 


\section{EXPERIMENTAL RESULTS}

\subsection{AXIAL SPECIMENS}

Individual strength measurements, grouped by extrusion lot, are listed in Appendix B (Tables B-1 through B-3). Nine specimens were lost or damaged during machining, and one strength value from a flawed specimen [2.7 $\mathrm{MPa}$ (392 psi)] was rejected. The first part of the specimen number identifies the parent $\mathrm{log}$, and the final letter identifies the axial distance of the specimen from the center of the $10 \mathrm{~g}$. The specimens were located along the axis between 25 and $127 \mathrm{~mm}$ ( 1 and $5 \mathrm{in.}$ ) from the center, with the A-specimens closest to the center and the D-specimens most distant.

Tables B-4 through B-6 in Appendix B list the average strength value for each $\log$, grouped by extrusion lot. The tables include the following information for each $\log$ :

1. A single strength measurement supplied by GLCC, from a cylindrical specimen $12.8 \mathrm{~mm}$ ( $0.505 \mathrm{in.}$ ) in diameter, taken on the $\log$ axis $343 \mathrm{~mm}$ (13.5 in.) from the midlength center.

2. The average of the four GA specimens closest to the center (subscripts $A$ and $B$ ).

3. The average of all eight GA specimens (subscripts A, B, C, and D).

Correlation between the values for GLCC's single specimen and the GA average values was poor. This difference probably reflects both the spatial separation of the sampling zones and the inherent randomness of a single specimen. Statistical tests showed no significant difference in mean values between the $A$ and $B$ specimens (located closest to the log center) and the $C$ and $D$ specimens; therefore, they can be treated as coming from the same population. 
There was no apparent correlation between strength and the position of the log within the graphitization furnace.

The average strengths and standard deviations for materia1 from each extrusion lot are listed in Table 1. The grand mean of $12.7 \mathrm{MPa}$ (1843 psi) compares with a value of $13.3 \mathrm{MPa}$ (1936 psi) obtained from GLCC's single specimens.

The differences in average strength between the three extrusion lots, shown in Table 1, were statistically highly significant. The small differences in standard deviation between the different extrusion lots were not statistically significant.

The difference between the average strengths of lots $472-478$ and 482 can be accounted for by GLCC differences in processing.

\subsection{RADIAL SPECIMENS}

The individual radial strength measurements are listed in Appendix $C$ (Tables C-1 through $\mathrm{C}-3$ ). Only specimens with an A or B subscript were tested. The specimens were located within $25 \mathrm{~mm}$ (1 in.) of the end of the parent $\log$ and within $51 \mathrm{~mm}$ ( 2 in.) of the centerline (see Fig. 3). The average strength values for each $\log$ are listed in Appendix $C$ (Tables C-4 through $\mathrm{C}-6$ ).

There was no statistically significant correlation between the radial strength and the axial strength of the same logs (correlation coefficient $0.11)$.

The average radial strengths and standard deviations for each extrusion lot are listed in Table 2. The grand mean was $15.8 \mathrm{MPa}$ (2291 psi). The difference in strength between lots 472 and 478 was not statistically significant, but lot 482 was significantly weaker than the other two lots. In contrast to the axial strengths the differences in standard deviation 
TABLE 1

STATISTICAL ANALYSIS OF AXIAL STRENGTH DATA

\begin{tabular}{c|c|c|c|c|c}
\hline \multirow{2}{*}{$\begin{array}{c}\text { Extrusion } \\
\text { Lot }\end{array}$} & \multirow{2}{*}{$\begin{array}{c}\text { Number of } \\
\text { Specimens Tested }\end{array}$} & \multicolumn{2}{|c|}{ Average Strength } & \multicolumn{2}{c}{ Standard Deviation } \\
\cline { 3 - 6 } 472 & 111 & 12.3 & 1779 & 2.9 & 420 \\
478 & 439 & 13.6 & 1976 & 2.8 & 400 \\
482 & 224 & 11.1 & 1616 & 2.7 & 389 \\
A11 & 774 & 12.7 & 1843 & 3.0 & 430 \\
\hline
\end{tabular}

TABLE 2

STATISTICAL ANALYSIS OF RADIAL STRENGTH DATA

\begin{tabular}{c|c|c|c|c|c}
\hline \multirow{2}{*}{$\begin{array}{c}\text { Extrusion } \\
\text { Lot }\end{array}$} & \multirow{2}{*}{$\begin{array}{c}\text { Number of } \\
\text { Specimens Tested }\end{array}$} & \multicolumn{2}{|c|}{ Average Strength } & \multicolumn{2}{c}{ Standard Deviation } \\
\cline { 3 - 6 } & 56 & 16.4 & 2380 & 1.4 & 209 \\
\hline 472 & 224 & 16.3 & 2364 & 1.8 & 256 \\
478 & 112 & 14.5 & 2100 & 2.7 & 389 \\
482 & 392 & 15.8 & 2291 & 2.2 & 318 \\
\hline
\end{tabular}


were statistically significant, with 1 ot 482 showing more variability than the other two lots. This was attributable to an increase in both the $\log$-to-log variability and the within-log (specimen-to-specimen) variability.

The higher strength and reduced standard deviation of the radial specimens at the end-center position compared with the axial specimens at the midlength-center position are not unusual and have been observed in preproduction logs. The differences between the three lots show that material extruded in different lots can vary considerably in strength properties after impregnation and graphitization. 


\section{APPLICATION OF RESULTS TO ACCEPTANCE TESTING}

\subsection{STRATEGY FOR ACCEPTANCE TESTING}

The results described in the previous section show that the strength of axial midlength-center specimens is both lower and more scattered than the strength of radial end-center specimens. Variations between extrusion lots and variations between logs within the same lot both contribute to the scatter. The log-to-log scatter is too great to allow qualification of entire lots. It is evident that acceptance tests intended to ensure minimum strength needs should be based on axial midlength-center specimens and that each log should be sampled. Additional tests on radial endcenter specimens would be of little value in qualifying logs because of the relatively high uniform strength of such material.

\subsection{STATISTICAL MODEL}

To develop logical acceptance criteria, the following statistical model was assumed:

$$
\mathbf{x}_{i j}=\mu+\alpha_{i}+\beta_{j}+\varepsilon_{i j},
$$

where $x_{i j}$ is an axial strength measurement from the $j^{\text {th }} \log$ in the $i^{\text {th }}$ lot, $\mu$ is the grand mean strength, $\alpha_{i}$ is the variation systematic to the $i^{\text {th }}$ lot, $\beta_{j}$ is the variation systematic to the $j^{\text {th }} \log$ from this $10 t$, and $\varepsilon_{i j}$ is the random variation (in the midlength-center sampling zone) within this $\log$. It was further assumed that $\alpha, \beta$, and $\varepsilon$ are norma11y and independently distributed with means of zero and variances of $\sigma_{1 \text { ot }}^{2}, \sigma_{\log }^{2}$, and $\sigma_{W L}^{2}$, respectively. The latter three quantities are, in order, the variances attributable to lot-to-lot variations, log-to-log variations, 
and within-log variations. It is implicit in the model that the log-to$\log$ variance is the same for all extrusion lots and the within-1og variance is the same for all logs.

Values for the three components of variance were calculated from the test data by the analysis of variance method. The calculations confirmed that both lot-to-lot and log-to-log variations were statistically highly significant. The values for $\sigma_{l o t}^{2}, \sigma_{10 g}^{2}$ and $\sigma_{\text {WL }}^{2}$ qre shown in Table 3 ; the corresponding standard deviations are also included.

Table 3 shows that the largest contributor to the spread in the axial strength measurements is the $\log -$ to- $\log$ variation among $\log$ from the same extrusion 1ot. On the other hand, the within-log variance [2.67 (MPa) $\left.{ }^{2}\right]$ is low enough for log-by-log acceptance tests based on a few specimens per $\log$ to be practicable.

\subsection{ACCEPTANCE CRITERIA}

The purpose of acceptance testing is to ensure that material from the midlength center (the weakest location) of the logs meets the minimum strength requirement, $S_{\text {min }}$, for a particular reactor core component. Because of the variability in graphite strengths, a statistical definition of "minimum strength" is required. For the present analysis the following two alternative definitions were considered:

90/90: At least $90 \%$ of the material at the midlength center of the $\log$ equals or exceeds the specified minimum strength, with $90 \%$ confidence.

99/95: At least $99 \%$ of the material at the midlength center of the $\log$ equals or exceeds the specified minimum strength, with 95\% confidence. 
TABLE 3

COMPONENTS OF VARIANCE: AXIAL STRENGTH DATA

\begin{tabular}{l|c|c|c|c|c}
\hline & & \multicolumn{2}{|c|}{ Variance } & \multicolumn{2}{c}{ Standard Deviation } \\
\cline { 3 - 6 } Source of Variation & Symbo1 & $\mathrm{MPa}^{2}$ & $\mathrm{psi}^{2}$ & $\mathrm{MPa}$ & psi \\
\hline Lot-to-lot & $\sigma_{\operatorname{lot}}^{2}$ & 1.22 & 25,533 & 1.10 & 160 \\
Log-to- $\log$ & $\sigma_{\log }^{2}$ & 5.22 & 109,905 & 2.29 & 332 \\
Within $\log$ (residual) & $\sigma_{\text {WL }}^{2}$ & 2.67 & 56,200 & 1.63 & 237 \\
\hline
\end{tabular}


An acceptance testing strategy which meets the needs can be derived from the statistical model of Eq. 1, if it is assumed that the present estimate of the within-log variance $\left[2.67(\mathrm{MPa})^{2}\right]$ is exact and will remain unchanged in future production runs. Suppose that $\mathrm{n}$ replicate specimens from the midlength center of a $\log$ are tested and their average, $\bar{x}$, is used to estimate the mean $\log$ strength, $\mu+\alpha_{i}+\beta_{j}$. The minimum strength requirement, $S_{\text {min }}$ will be met if $\bar{x}$ meets the following criterion:

$$
\overline{\mathrm{x}} \geq \mathrm{S}_{\min }+1.282 \sigma_{\mathrm{WL}}+\frac{1.282}{\sqrt{\mathrm{n}}} \sigma_{\mathrm{WL}}
$$

if the $90 / 90$ definition of minimum strength is used, or

$$
\bar{x} \geq S_{\min }+2.326 \sigma_{W L}+\frac{1.645}{\sqrt{n}} \sigma_{W L}
$$

if the more stringent $99 / 95$ definition of minimum strength is used. The numerical factors in Eq. 2 come from tabulated values for the standard norma1 distribution.

Different components in the HTGR core experience different stress levels. Therefore, the following three strength categories were considered:

$$
\begin{aligned}
& \text { Category A: minimum strength } 10.3 \mathrm{MPa}(1500 \mathrm{psi}) \\
& \text { Category B: minimum strength } 8.3 \mathrm{MPa}(1200 \mathrm{psi}) \\
& \text { Category C: minimum strength } 5.5 \mathrm{MPa} \text { ( } 800 \mathrm{psi})
\end{aligned}
$$

The value which $\bar{x}$ must exceed for a $\log$ to be assigned to category $A, B$, or $\mathrm{C}$ can be calculated from Eq. 2. Values are shown in Table 4 for both four and eight replicate tests per $10 \mathrm{~g}$, and for both the $90 / 90$ and the 99/95 definitions of minimum strength.

The criteria 1isted in Table 4 were applied to each of the 98 tested logs. For the case requiring four replicate tests, the four specimens closest to the $\log$ center (subscripts A and B) were used. The assigned 
TABLE 4

CRITERIA FOR ASSIGNING LOGS TO STRENGTH

CATEGORIES A, B, OR C (AXIAL DATA)

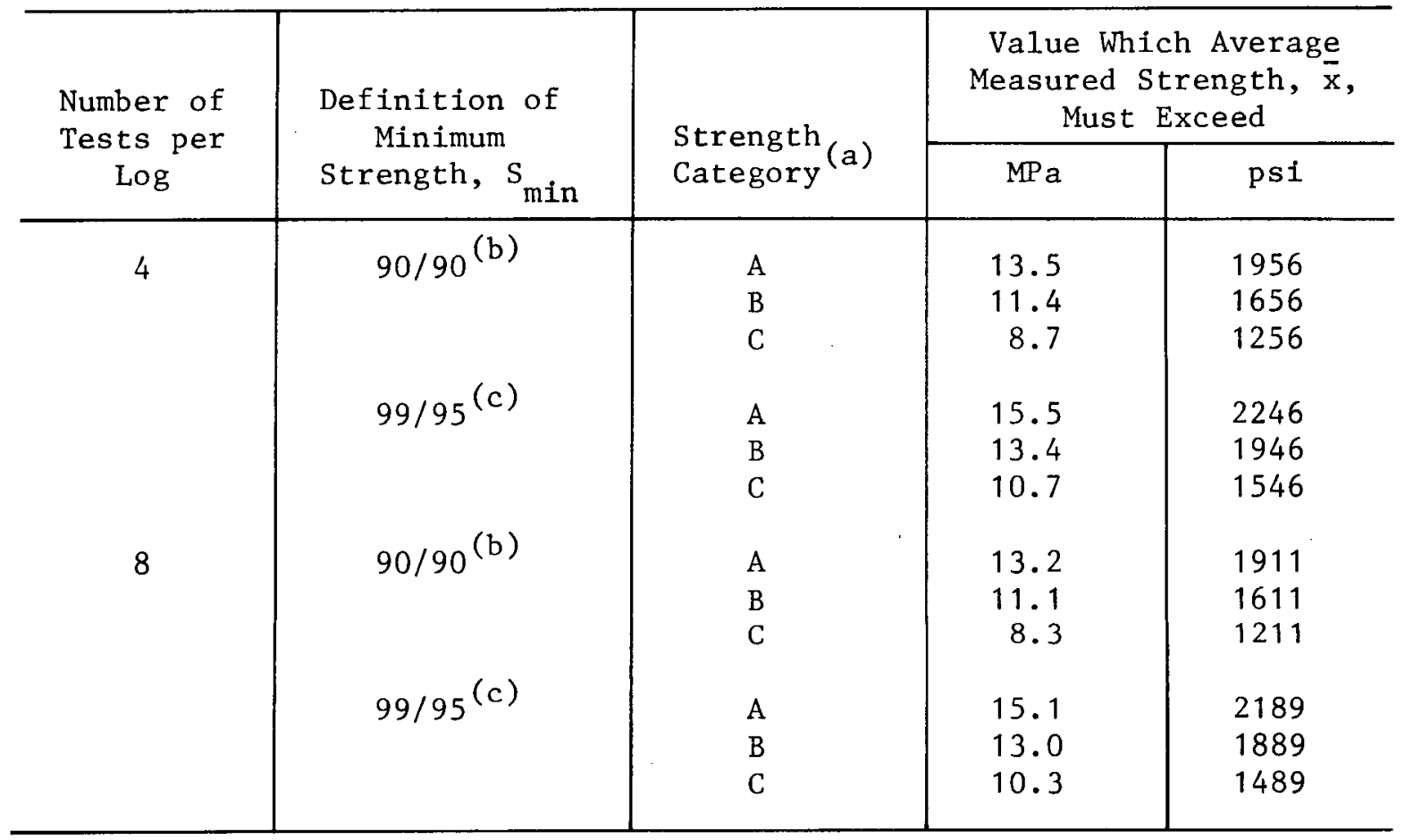

${ }^{\text {(a) }}$ Categories correspond to the following minimum strengths:
A: $10.3 \mathrm{MPa}(1500 \mathrm{psi})$
$\mathrm{B}: \quad 8.3 \mathrm{MPa}(1200 \mathrm{psi})$
C: $\quad 5.5 \mathrm{MPa}(800 \mathrm{psi})$

(b) At least $90 \%$ of material at midlength center exceeds specified minimum strength, with $90 \%$ confidence.

(c) At 1east $99 \%$ of material at midlength center exceeds specified minimum strength, with $95 \%$ confidence. 
category for each $\log$ is given in Appendix B (Tables B-4 through B-6) for both a four-specimen and an eight-specimen sampling plan, and for both the loose and the more stringent definitions of minimum strength.

\subsection{YIELDS OF LOGS BY CATEGORY}

A summary of the numbers of logs assigned to each category under four-specimen and eight-specimen sampling plans, applying either of the two definitions of minimum strength, is given in Table 5 . The results are broken down by extrusion 1ot.

Using the less stringent $90 / 90$ definition of minimum strength and an eight-specimen sampling plan, only two logs would be rejected as failing to qualify for strength category $C$, and almost half the logs would qualify for category $A$. If the more stringent $99 / 95$ definition is used, 18 logs would be rejected and about $20 \%$ of the remainder would qualify for category A. A typical order of logs for a replacement segment of an HTGR core would require about $25 \%$ of the accepted logs to qualify for category $A$ and $70 \%$ to qualify for $A$ or $B$. If the $99 / 95$ minimum strength definition were adopted in place of the 90/90 definition, the yields in the higher categories would fall just short of these requirements, based on the quality of the production for all 98 logs considered in this order.

The effect on the yields of reducing the number of tests per $10 \mathrm{~g}$ from eight to four is fairly small. The number of rejects would increase from two to five under the $90 / 90$ strength definition, and rejects would be increased from 18 to 22 under the $99 / 95$ strength definition. There would be some overall downgrading because more borderline logs would be moved down in category than would be moved up.

The better quality of extrusion lot 478, indicated by its higher average strength in Table 1 , is clearly reflected in the yields listed in Table 5. Even using the $99 / 95$ definition of minimum strength, only two of the 56 logs in lot 478 would be rejected and $25 \%$ would meet category A requirements. 
TABLE 5

YIELDS OF LOGS IN EACH STRENGTH

CATEGORY ( BASED ON AXIAL STRENGTHS)

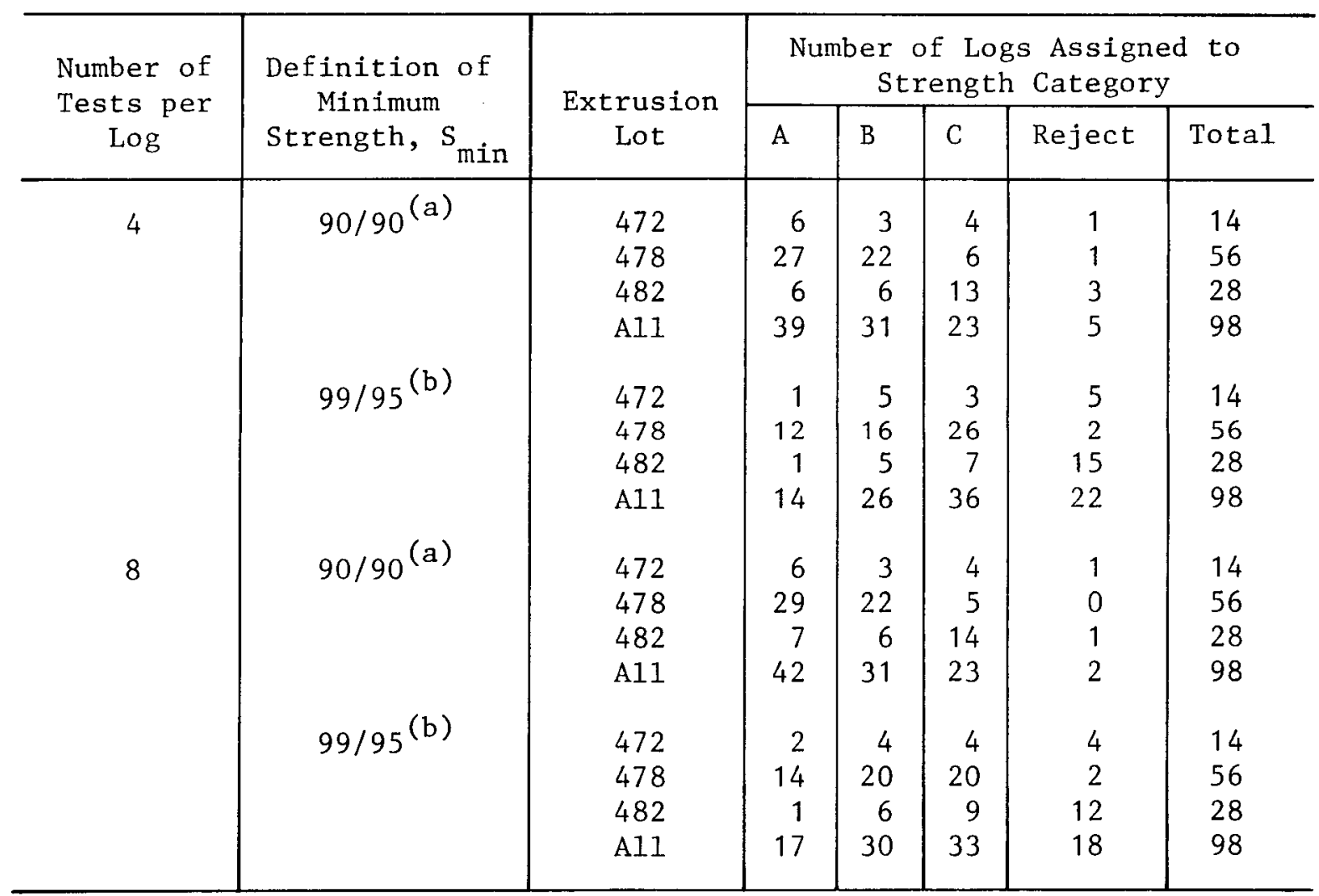

(a) At least $90 \%$ of material at midlength center exceeds specified minimum strength, with $90 \%$ confidence.

(b) At 1east $99 \%$ of material at midlength center exceeds specified minimum strength, with $95 \%$ confidence. 


\section{ACKNOWLEDGMENTS}

The authors express their thanks to C. H. Richards, Jr., J. R. Whaley, and M. G. Dunlap for performing the strength tests. L. H. Juel, A. A. Cline, and F. J. Wallis of Great Lakes Carbon Corporation are acknowledged for their cooperation and helpful comments during the course of the work. 


\section{REFERENCES}

1. Johnson, W. R., and G. B. Engle, "Properties of Unirradiated Fuel Element Graphites H-451 and TS-1240," ERDA Report GA-A13752, General Atomic Company, January 31, 1976.

2. Engle, G. B., and W. R. Johnson, "Properties of Unirradiated Fuel Element Graphites H-451 and S0818," ERDA Report GA-A14068, General Atomic Company, October 8, 1976.

3. Price, R. J., and L. A. Beavan, "Fina1 Report on Graphite Irradiation Test OG-1," ERDA Report GA-A13089, General Atomic Company, August 1, 1974 .

4. Price, R. J., and L. A. Beavan, "Final Report on Graphite Irradiation Test OG-2," ERDA Report GA-A13556, General Atomic Company, December 15, 1975.

5. Price, R. J., and L. A. Beavan, "Final Report on Graphite Irradiation Test OG-3," ERDA Report GA-A14211, General Atomic Company, January 1977. 
APPENDIX A

IDENTIFICATION NUMBERS AND DENSITIES OF LOGS IN EXTRUSION LOTS 472, 478, AND 482 
TABLE A-1

IDENTIFICATION NUMBERS AND DENSITIES OF LOGS IN EXTRUSION LOT 472

\begin{tabular}{c|c|c|c|c}
\hline $\begin{array}{c}\text { GA Log Number } \\
(7194-)\end{array}$ & $\begin{array}{c}\text { GLCC Log Number } \\
(1272-)\end{array}$ & $\begin{array}{c}\text { GLCC Serial } \\
\text { Number }\end{array}$ & $\begin{array}{c}\text { Position in Graphitizing } \\
\text { Furnace } \# 51\end{array}$ & $\begin{array}{c}\text { Log Density } \\
\left(\mathrm{Mg} / \mathrm{m}^{3}\right)\end{array}$ \\
\hline 16 & 22 & 10026 & $2-6$ & 1.74 \\
20 & 18 & 10034 & $3-4$ & 1.75 \\
26 & 48 & 10044 & $4-4$ & 1.73 \\
29 & 29 & 10051 & $5-1$ & 1.77 \\
40 & 30 & 10066 & $6-6$ & 1.73 \\
42 & 14 & 10072 & $7-2$ & 1.73 \\
46 & 26 & 10076 & $7-6$ & 1.75 \\
55 & 13 & 10093 & $9-3$ & 1.74 \\
75 & 12 & 10125 & $12-5$ & 1.74 \\
78 & 28 & 10132 & $13-2$ & 1.73 \\
84 & 23 & 10142 & $14-2$ & 1.74 \\
94 & 24 & 10156 & $15-6$ & 1.74 \\
96 & 45 & 10162 & $16-2$ & 1.74 \\
105 & 34 & 10176 & $17-6$ & 1.73 \\
\hline
\end{tabular}


TABLE A-2

IDENTIFICATION NUMBERS AND DENSITIES OF LOGS IN EXTRUSION LOT 478

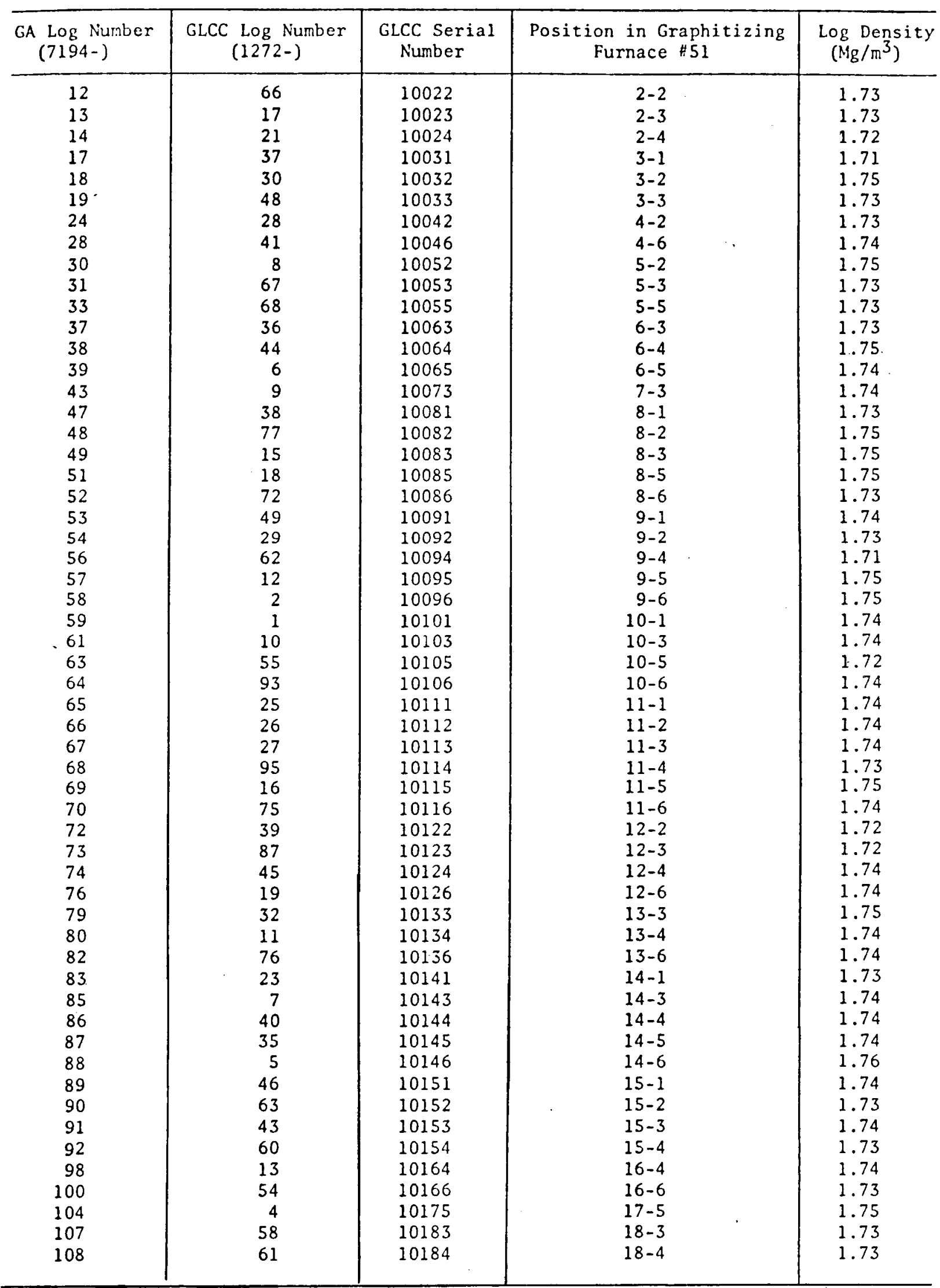


TABLE A-3

IDENTIFICATION NUMBERS AND DENSITIES OF LOGS IN EXTRUSION LOT 482

\begin{tabular}{c|c|c|c|c}
\hline $\begin{array}{c}\text { GA Log Number } \\
(7194-)\end{array}$ & $\begin{array}{c}\text { GLCC Log Number } \\
(1272-)\end{array}$ & $\begin{array}{c}\text { GLCC Serial } \\
\text { Number }\end{array}$ & $\begin{array}{c}\text { Position in Graphitizing } \\
\text { Furnace } \# 51\end{array}$ & $\begin{array}{c}\text { Log Density } \\
\left(\mathrm{Mg} / \mathrm{m}^{3}\right)\end{array}$ \\
\hline 11 & 118 & 10021 & $2-1$ & 1.72 \\
15 & 136 & 10025 & $2-5$ & 1.74 \\
21 & 147 & 10035 & $3-5$ & 1.73 \\
22 & 126 & 10036 & $3-6$ & 1.74 \\
23 & 113 & 10041 & $4-1$ & 1.75 \\
25 & 153 & 10043 & $4-3$ & 1.74 \\
27 & 102 & 10045 & $4-5$ & 1.73 \\
32 & 121 & 10054 & $5-4$ & 1.72 \\
34 & 54 & 10056 & $5-6$ & 1.72 \\
35 & 50 & 10061 & $6-1$ & 1.74 \\
36 & 129 & 10062 & $6-2$ & 1.75 \\
41 & 144 & 10071 & $7-1$ & 1.77 \\
44 & 114 & 10074 & $7-4$ & 1.73 \\
45 & 122 & 10075 & $7-5$ & 1.75 \\
50 & 111 & 10084 & $8-4$ & 1.73 \\
60 & 110 & 10102 & $10-2$ & 1.71 \\
62 & 44 & 10104 & $10-4$ & 1.73 \\
71 & 108 & 10121 & $12-1$ & 1.72 \\
77 & 53 & 10131 & $13-1$ & 1.73 \\
81 & 104 & 10135 & $13-5$ & 1.72 \\
93 & 132 & 10155 & $15-5$ & 1.73 \\
95 & 155 & 10161 & $16-1$ & 1.74 \\
97 & 115 & 10163 & $16-3$ & 1.72 \\
99 & 151 & 10165 & $16-5$ & 1.73 \\
101 & 134 & 10171 & $17-1$ & 1.73 \\
102 & 150 & 10173 & $17-3$ & \\
103 & 123 & 10174 & $17-4$ & \\
106 & 117 & 10181 & $18-1$ & \\
& & & & \\
\hline
\end{tabular}


APPENDIX B

AXIAL TENSILE STRENGTH MEASUREMENTS FOR EXTRUSION LOTS 472, 478, AND 482 
TABLE B-1

AXIAL TENSILE STRENGTH MEASUREMENTS: EXTRUSION LOT 472

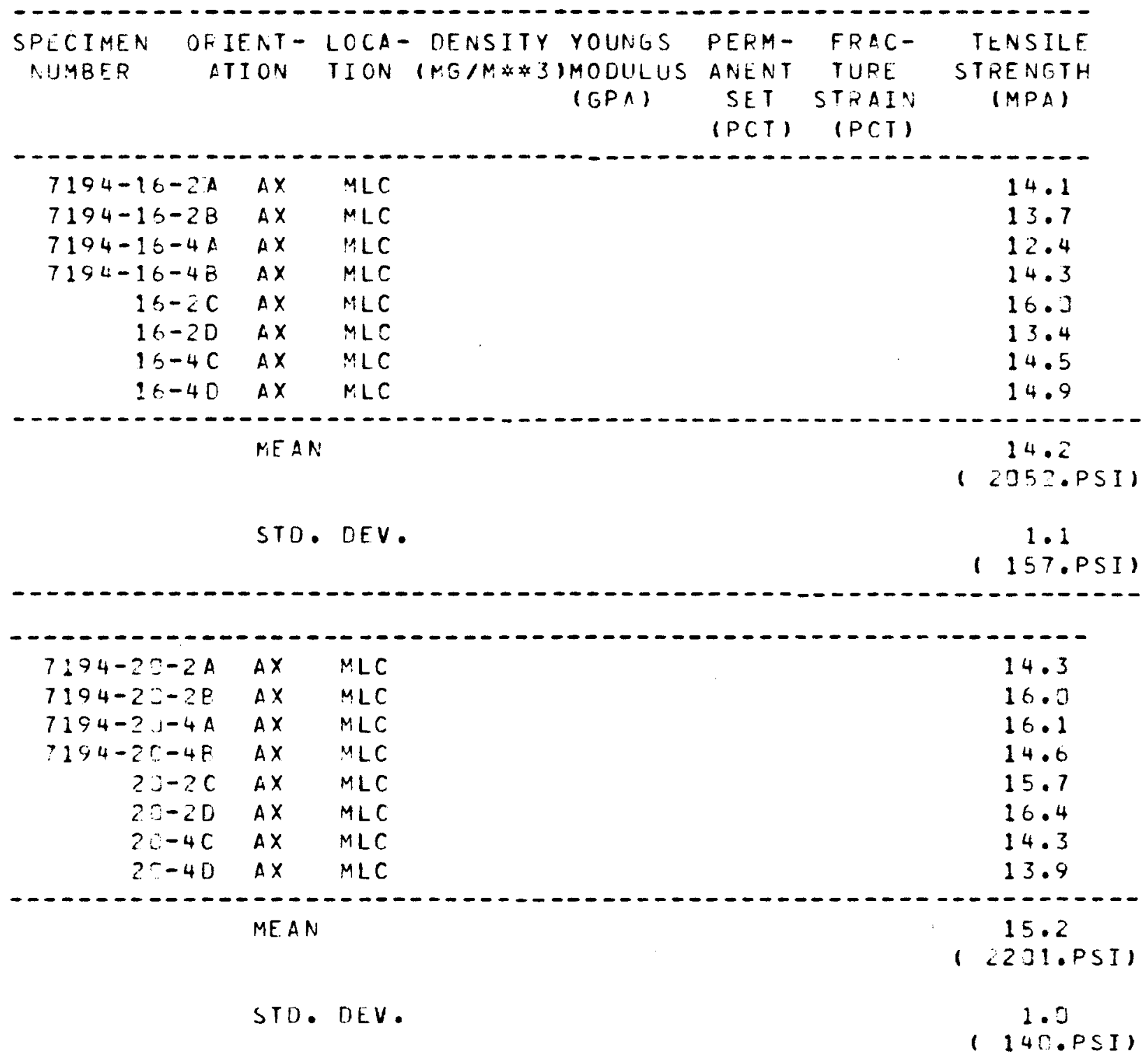

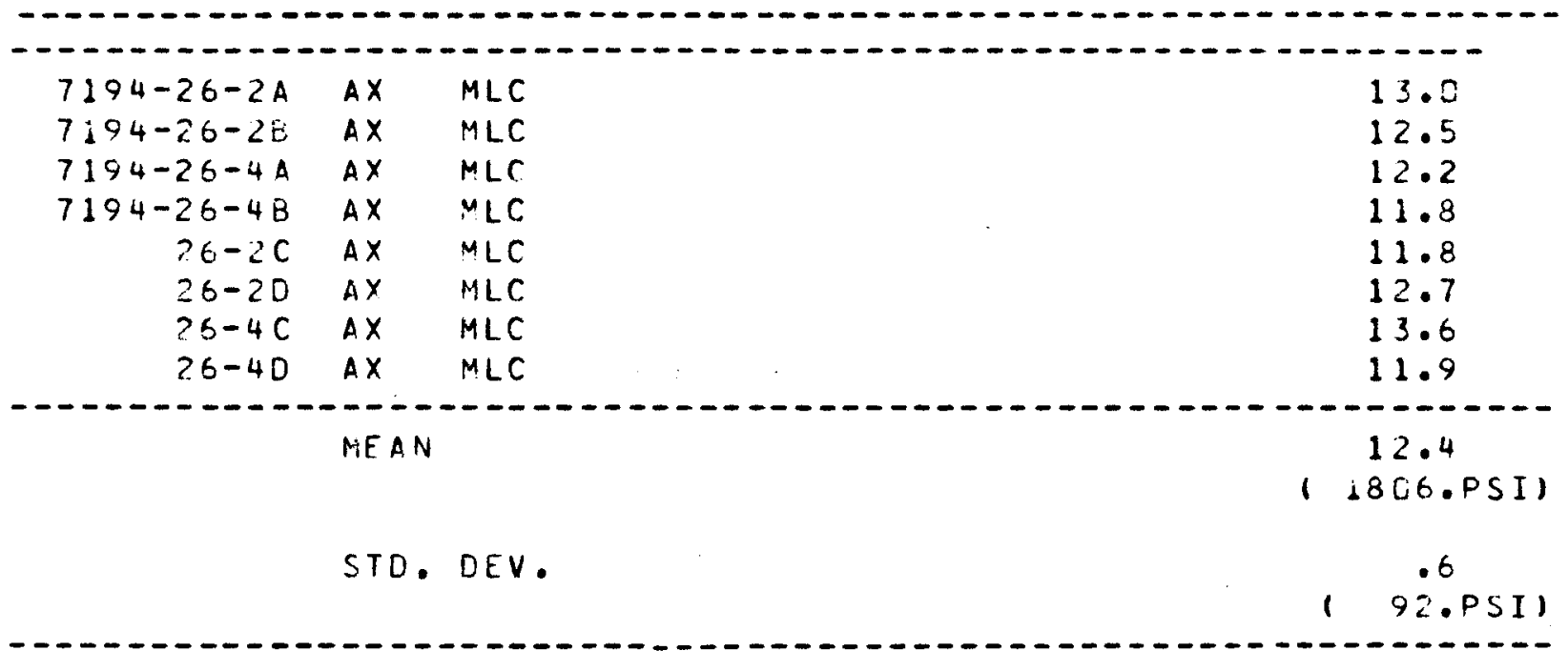


TABLE B-1 (Continued)

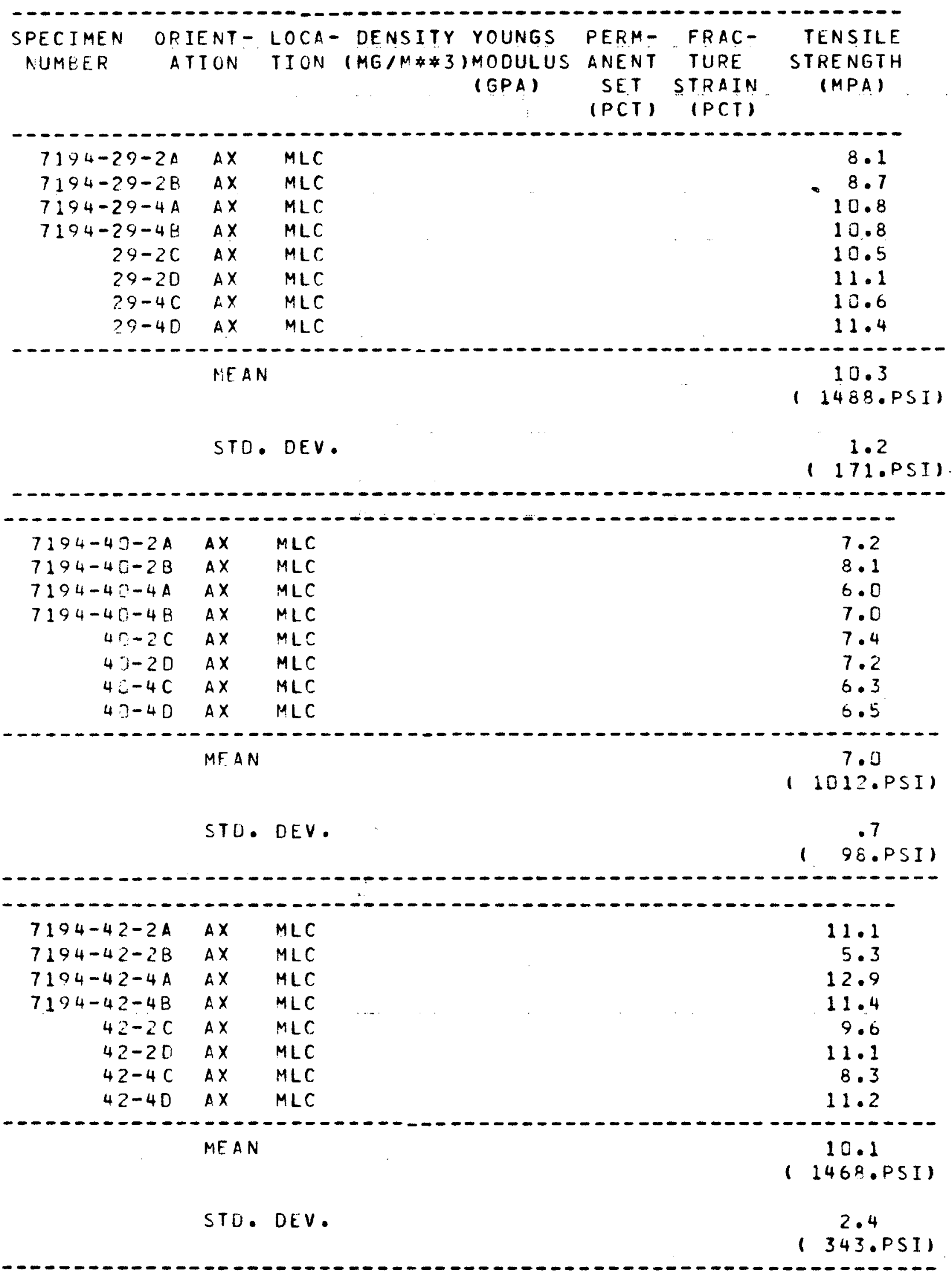


TABLE B-1 (Continued)

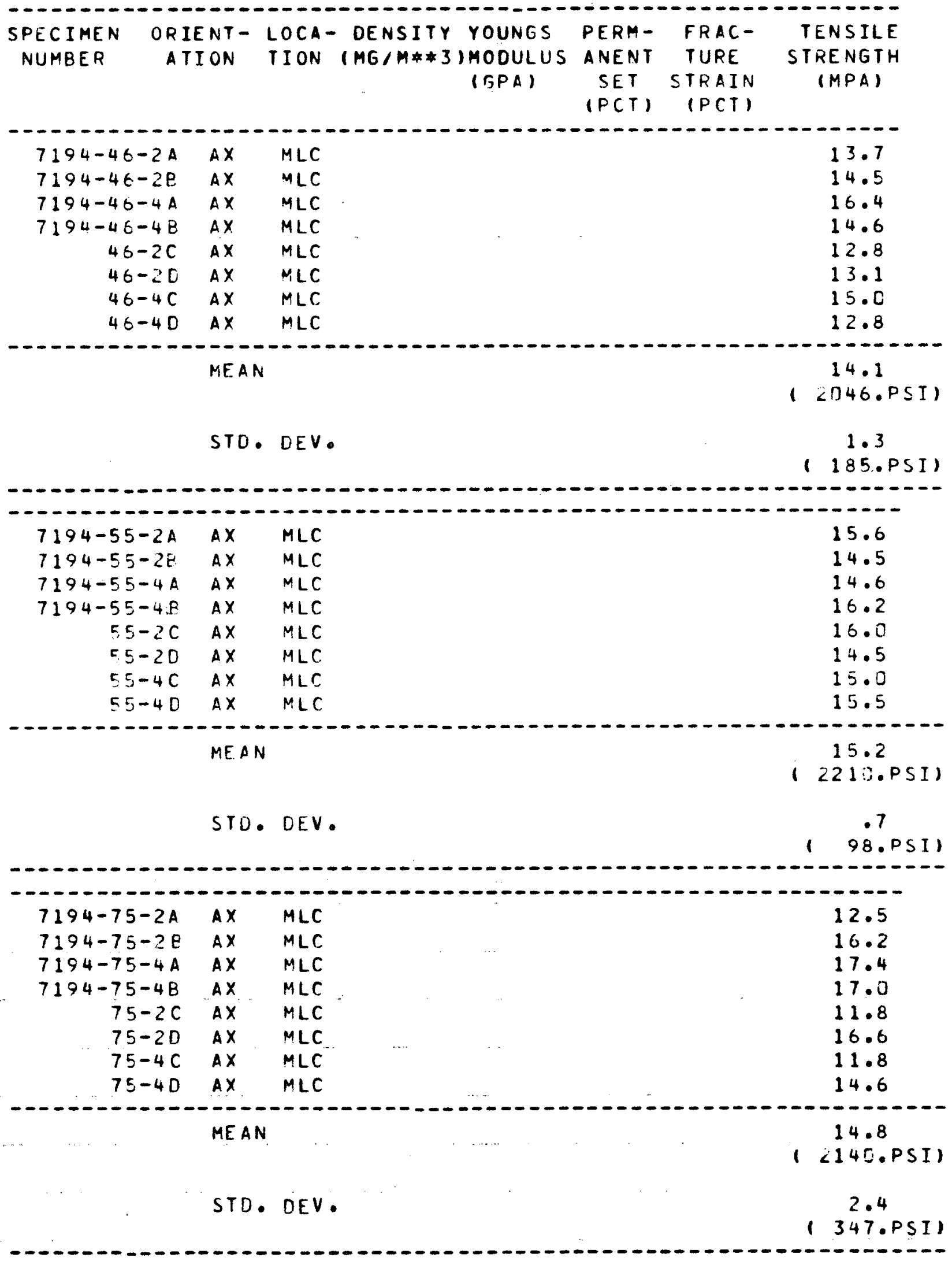


TABLE B-1 (Continued)

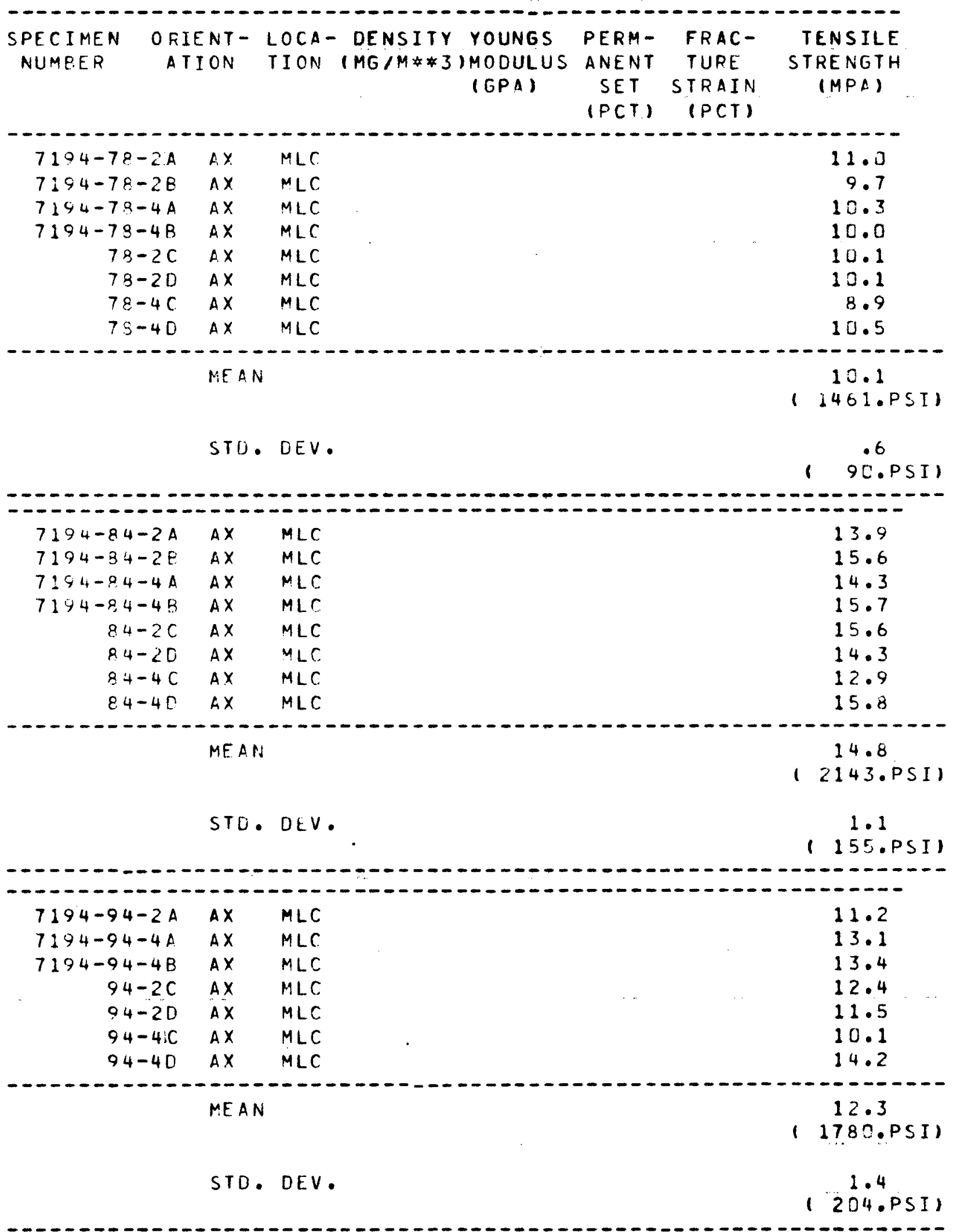


TABLE B-1 (Continued)

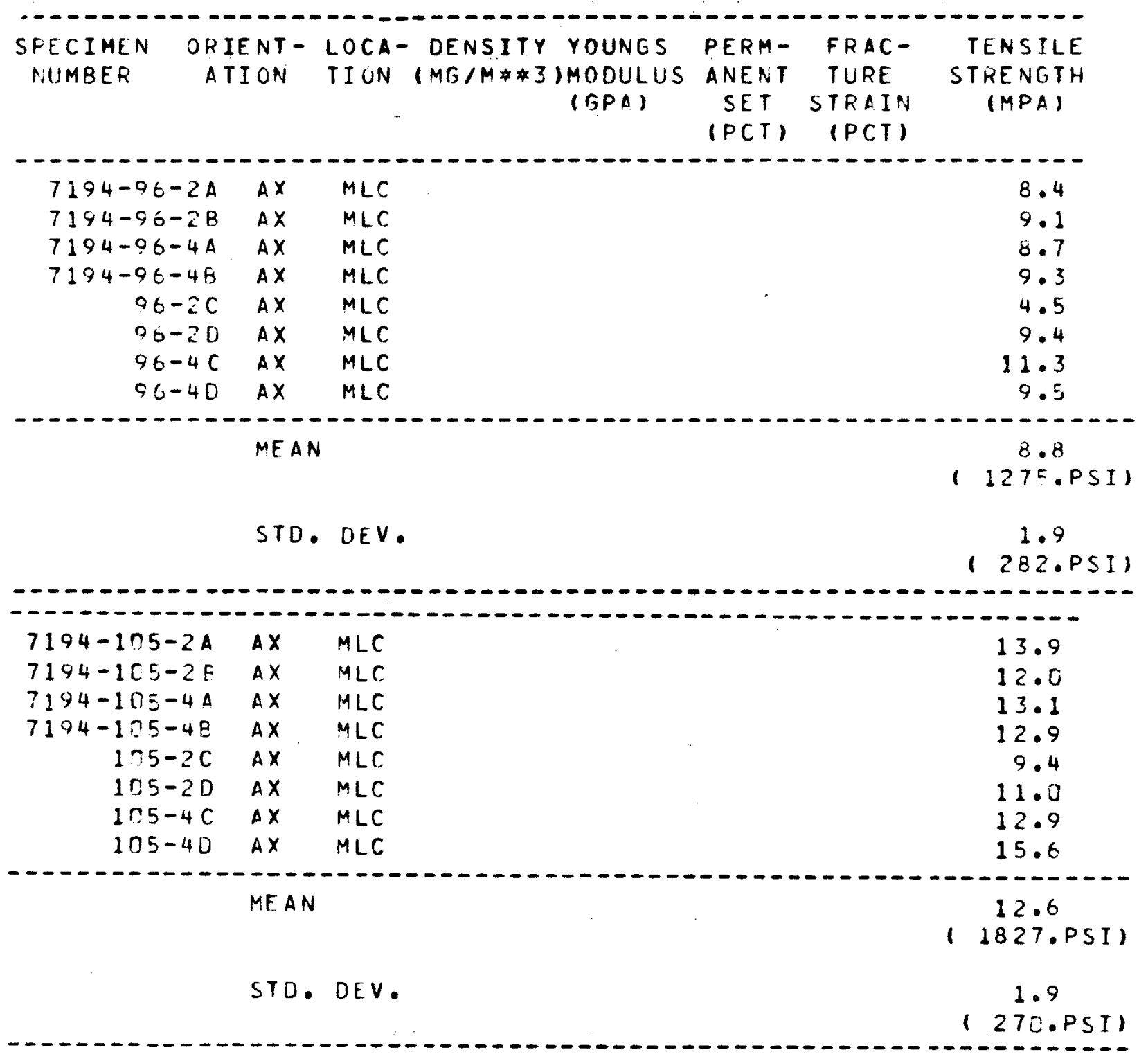


TABLE B-2

AXIAL TENSILE STRENGTH MEASUREMENTS: EXTRUSION LOT 478

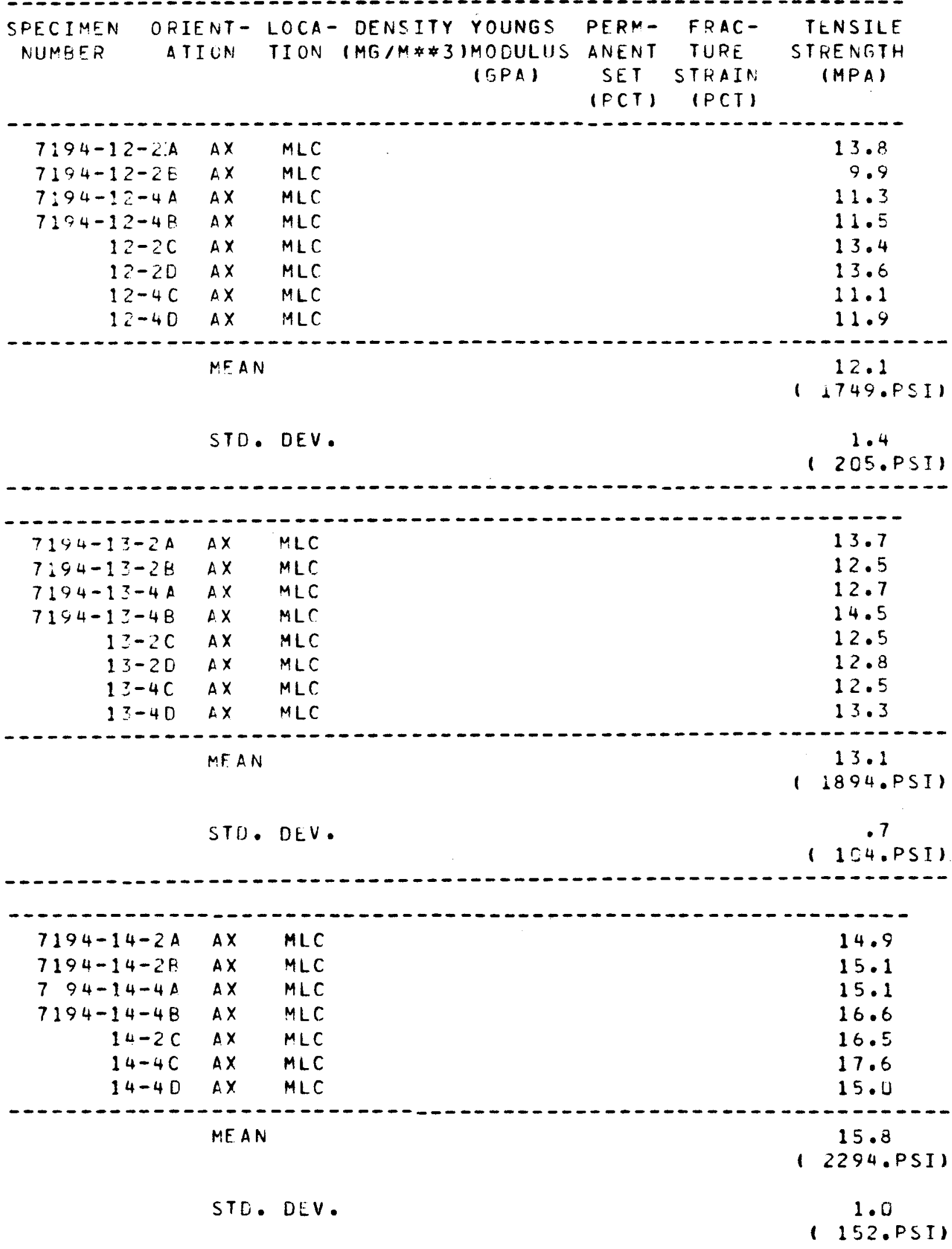


TABLE B-2 (Continued)

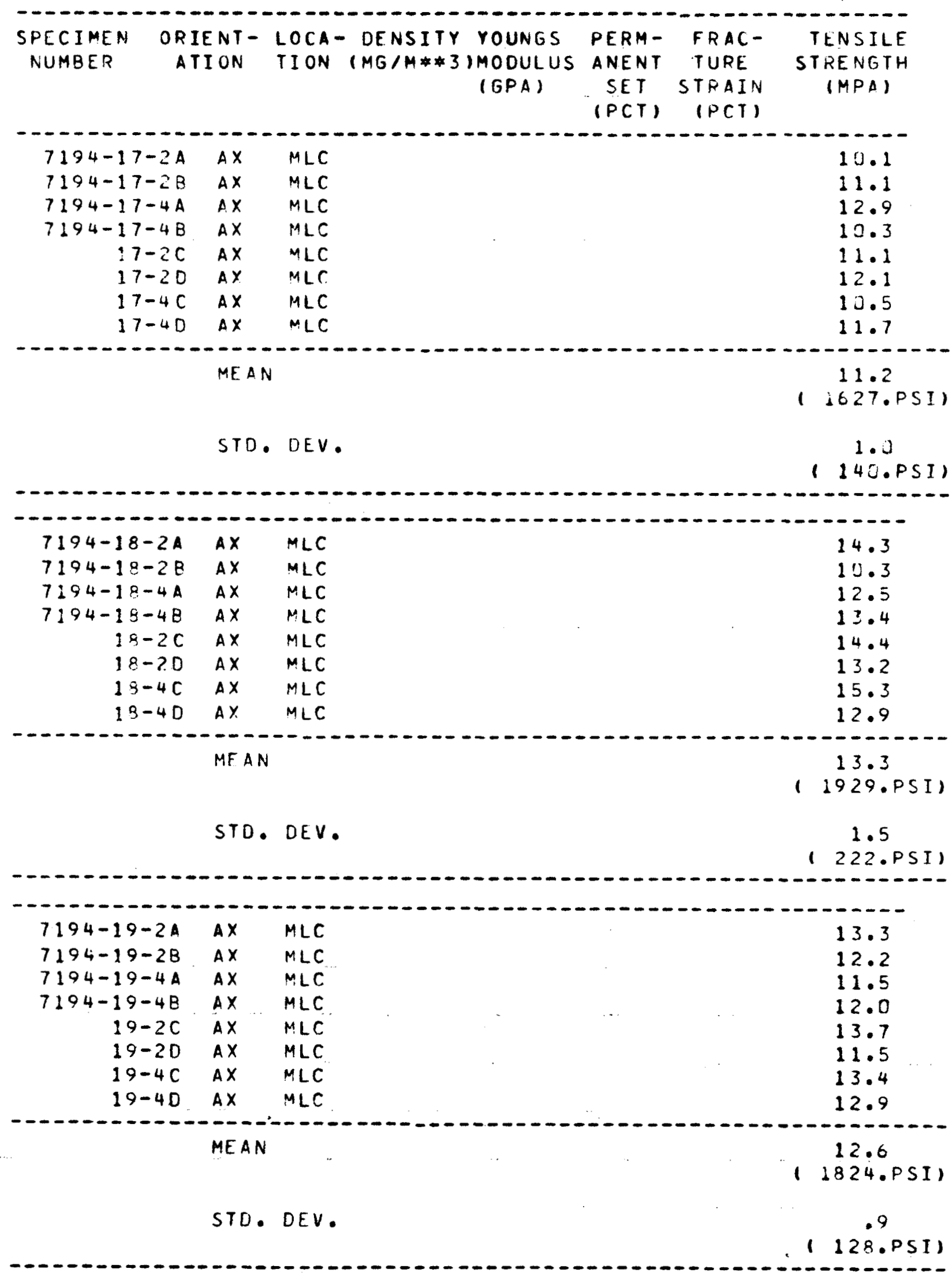




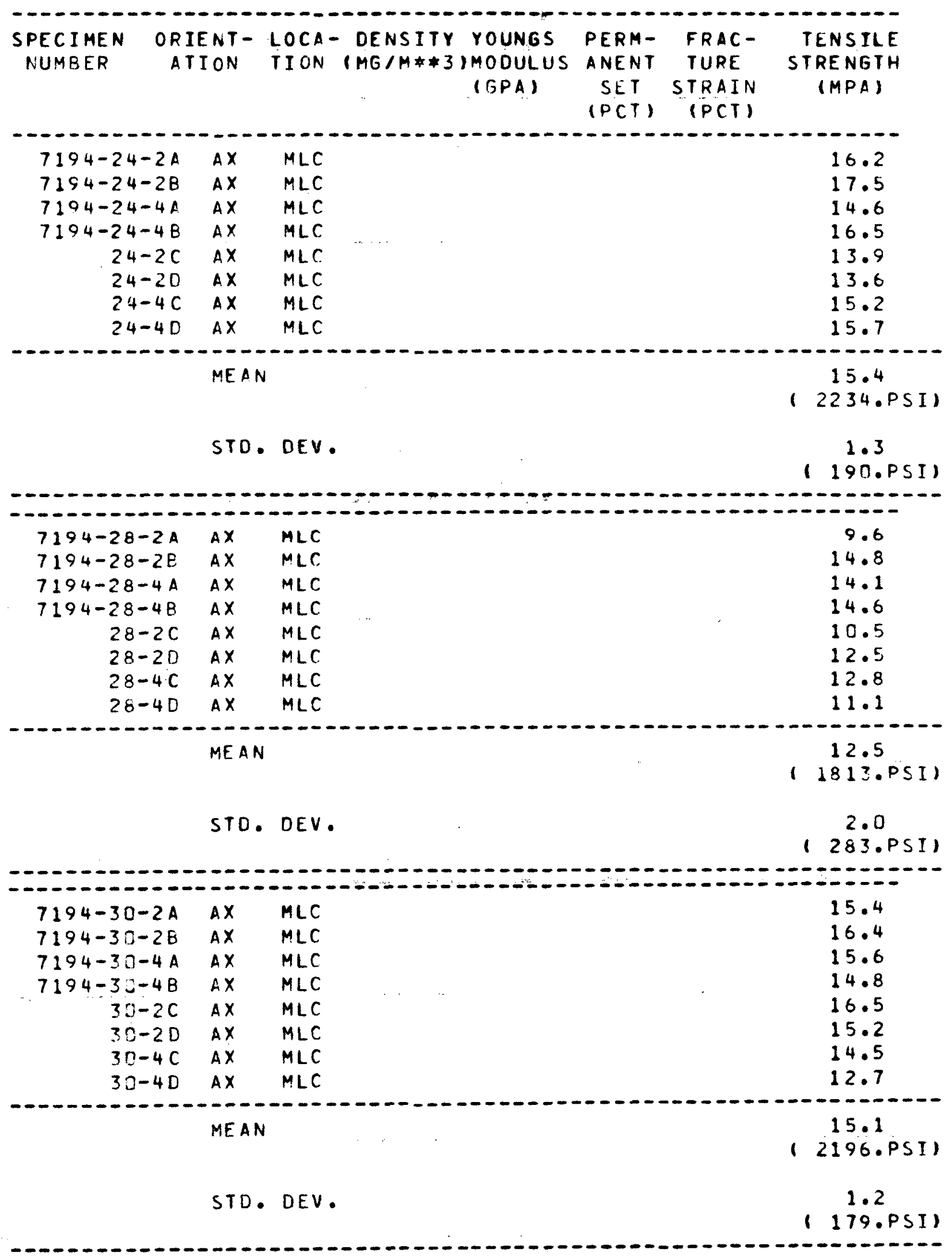


TABLE B-2 (Continued)

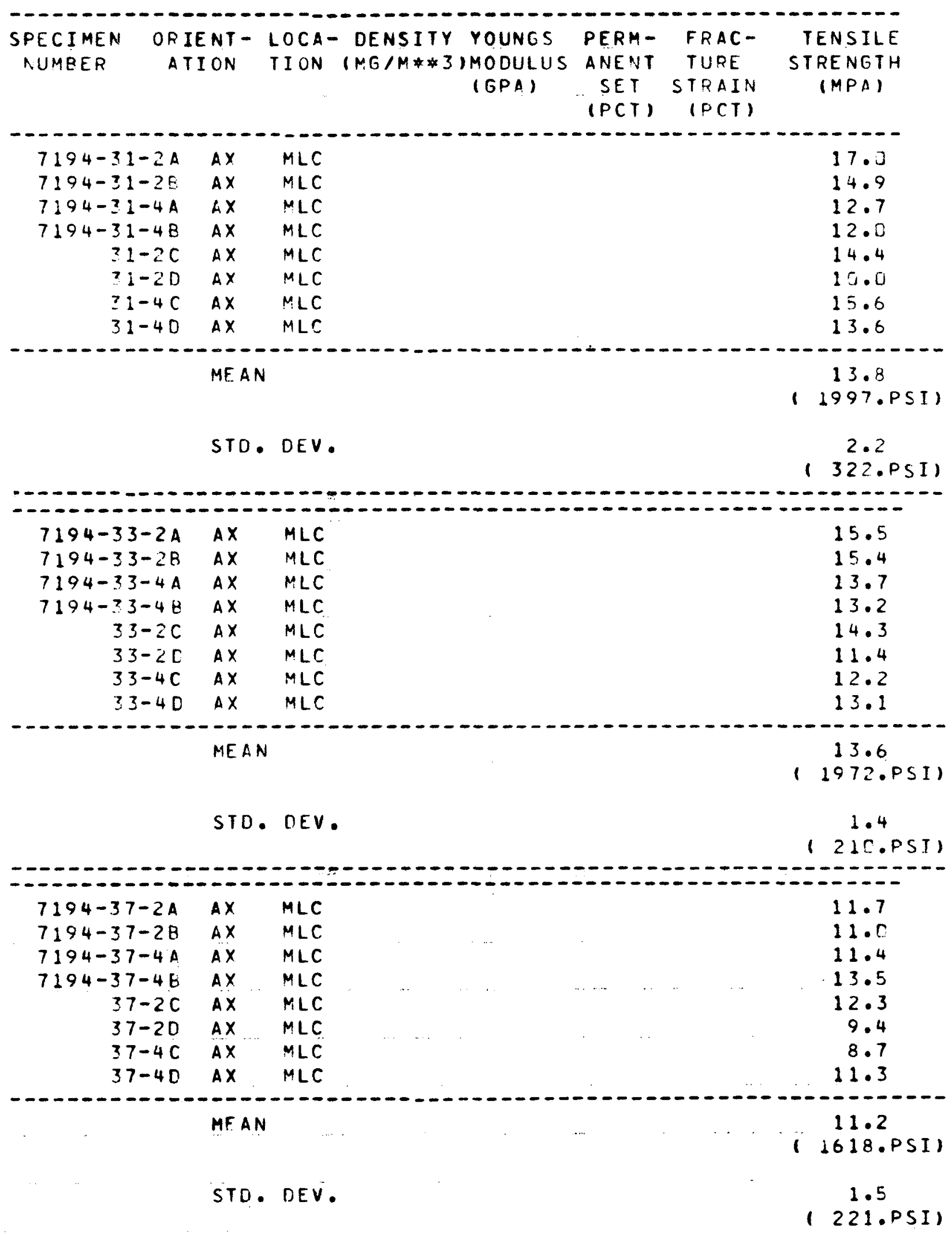


TABLE B-2 (Continued)

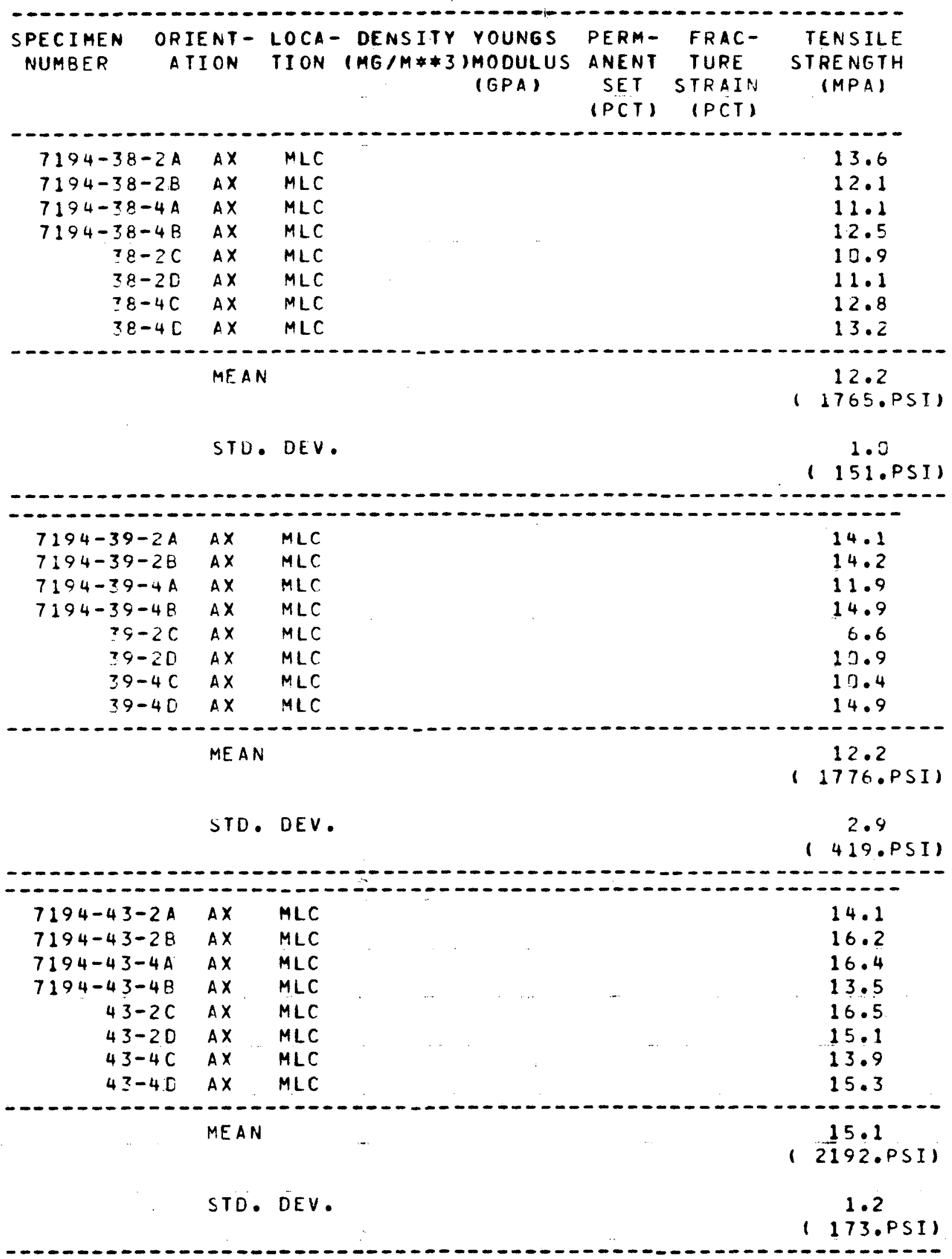


TABLE B-2 (Continued)

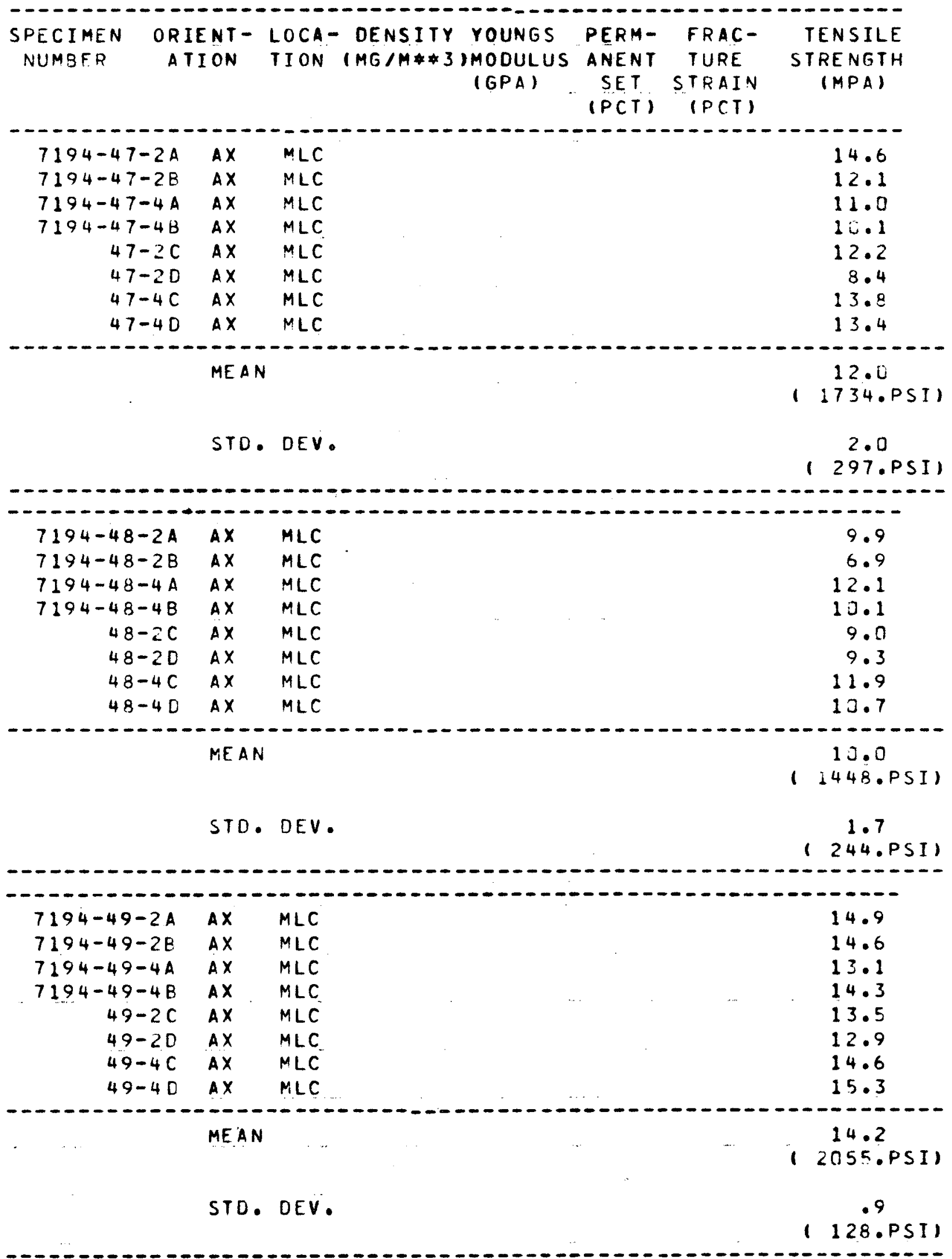


TABLE B-2 (Continued)

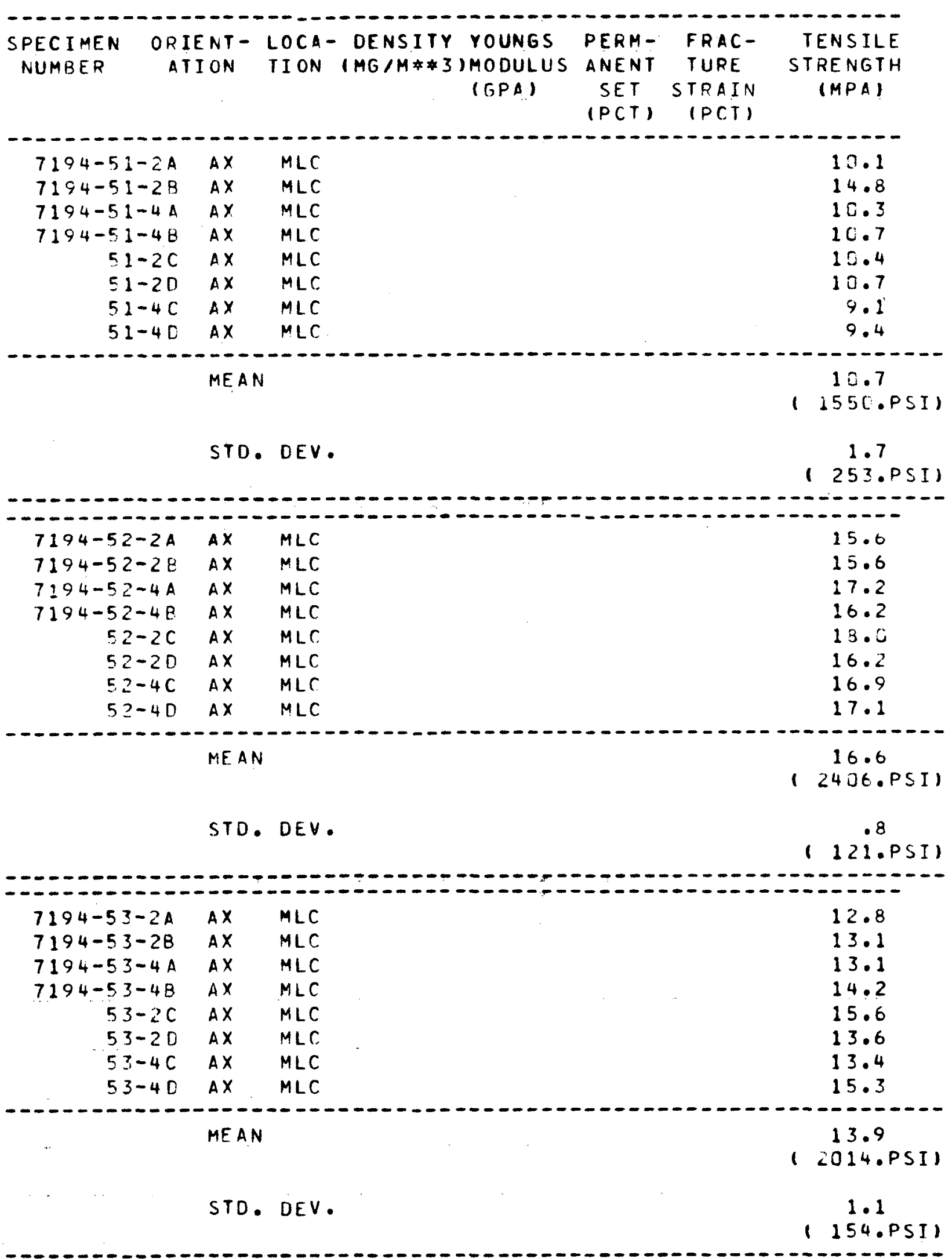


TABLE B-2 (Continued)

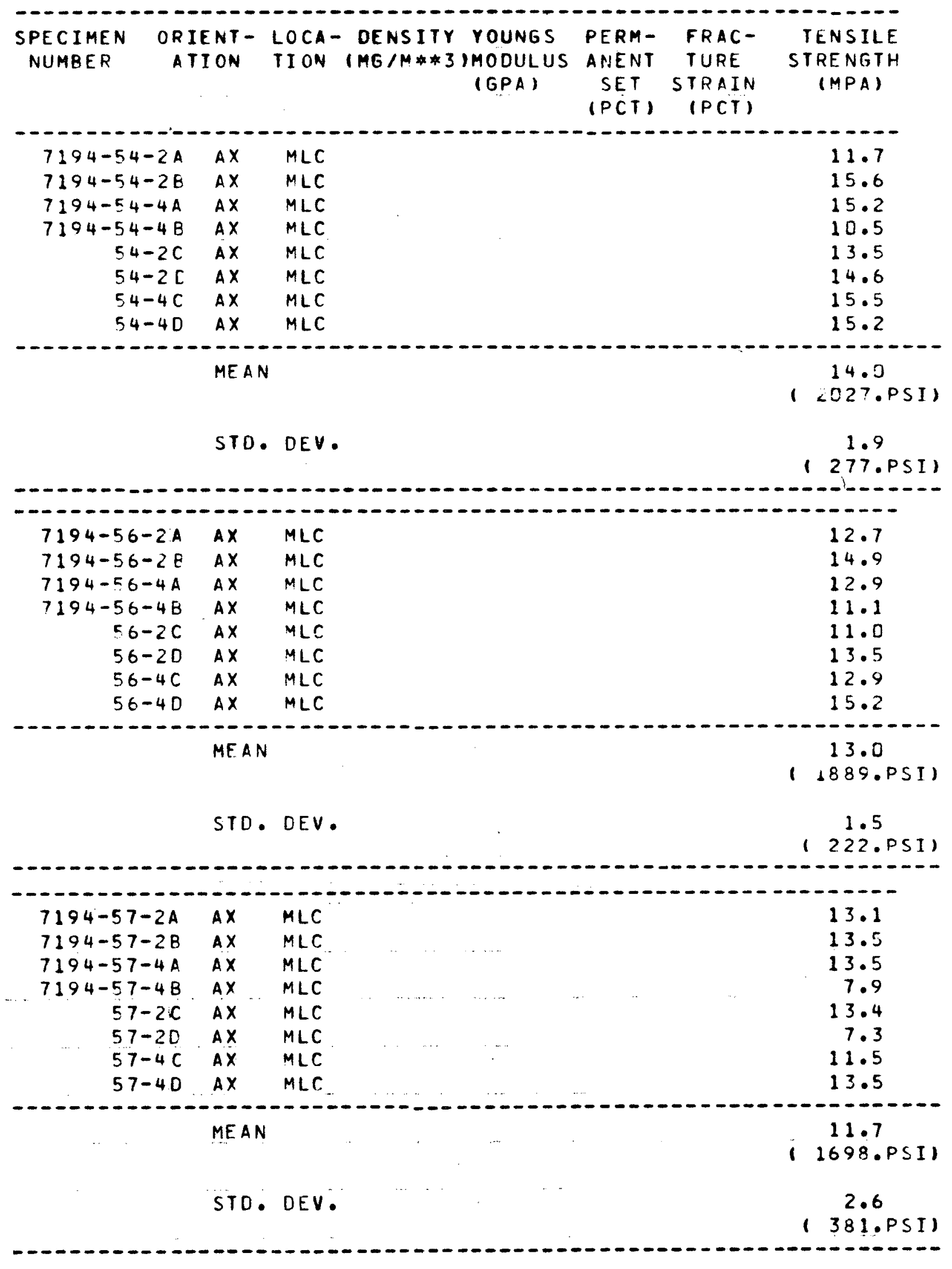


TABLE B-2 (Continued)

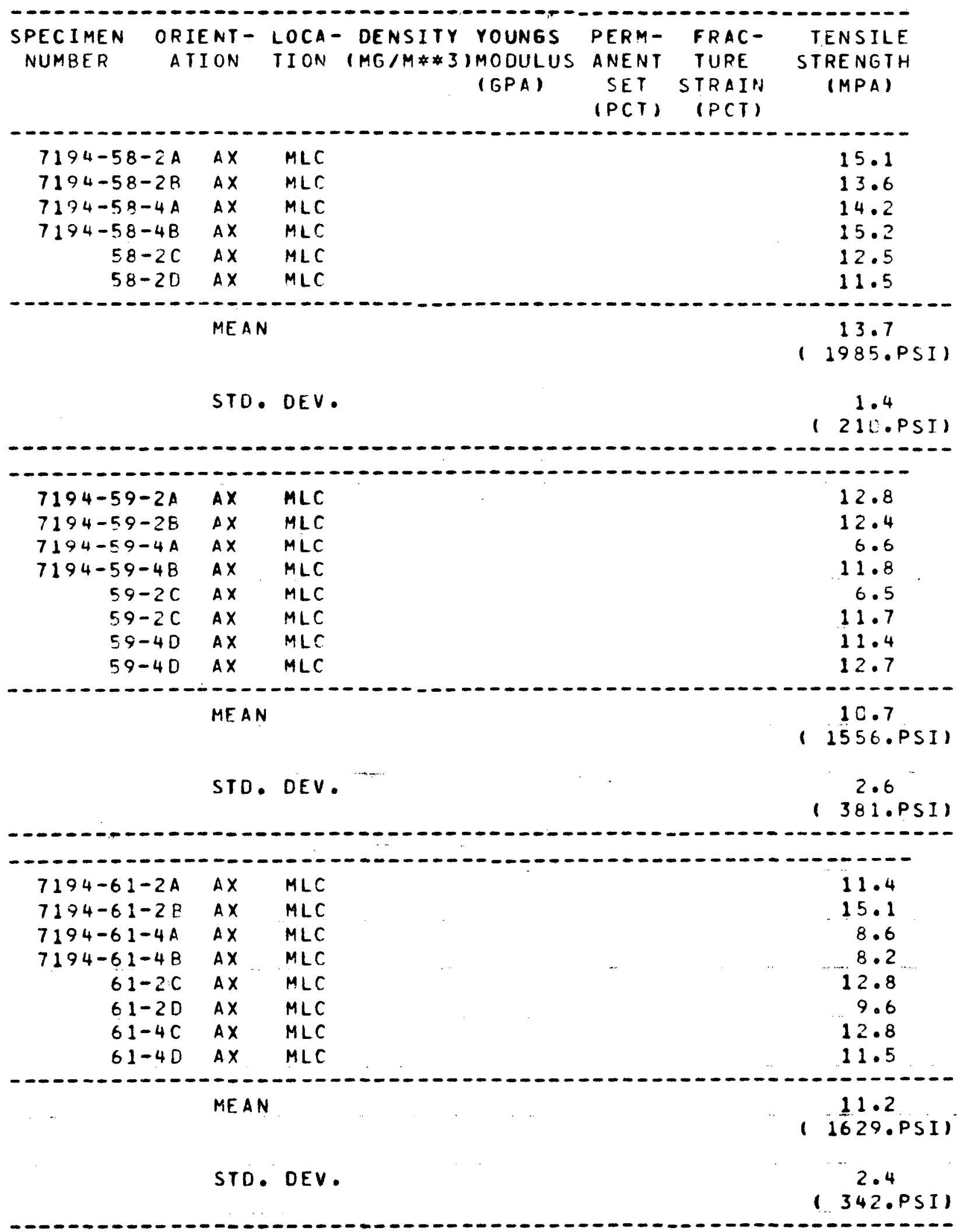


TABLE B-2 (Continued)

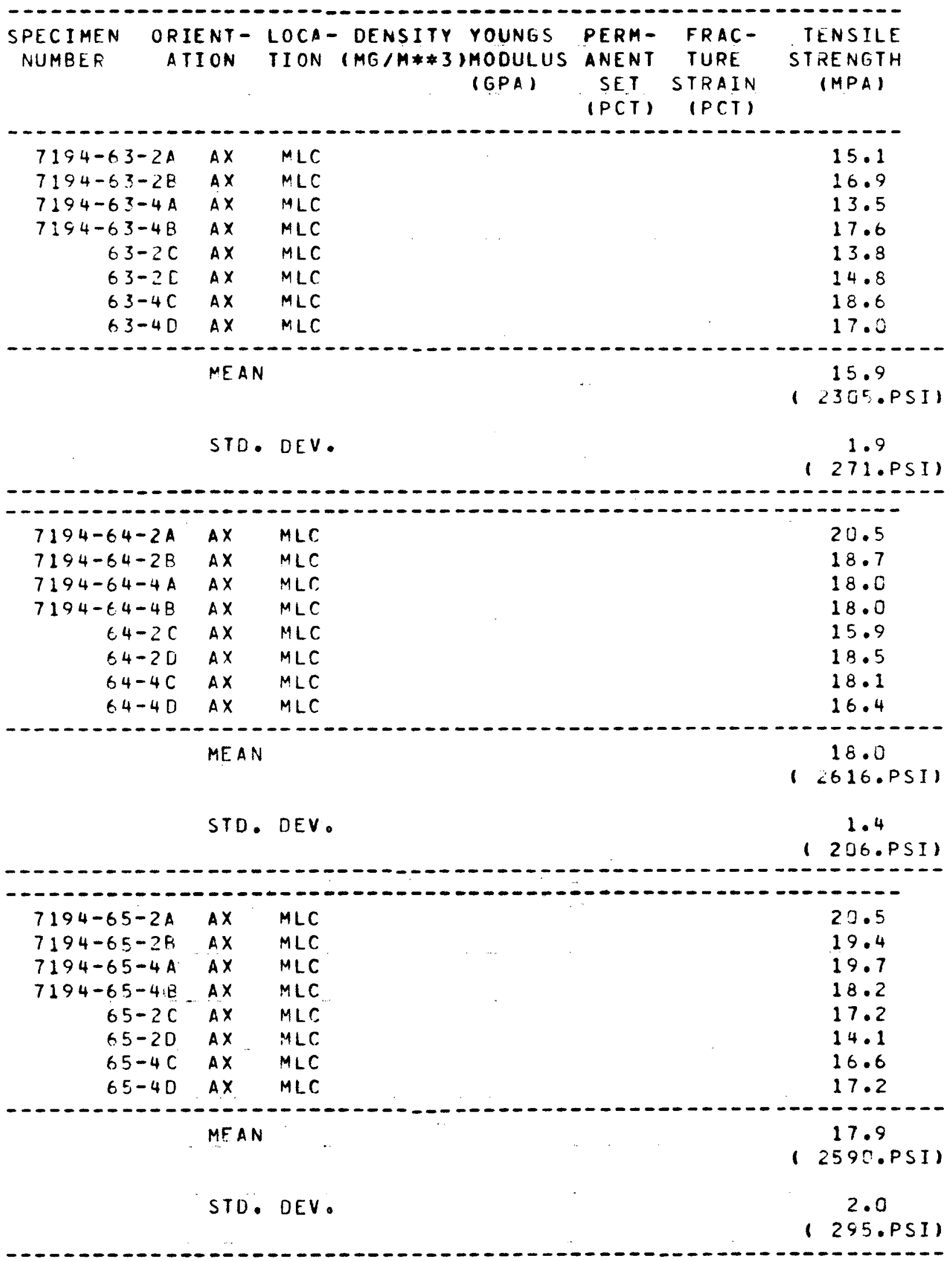


TABLE B-2 (Continued)

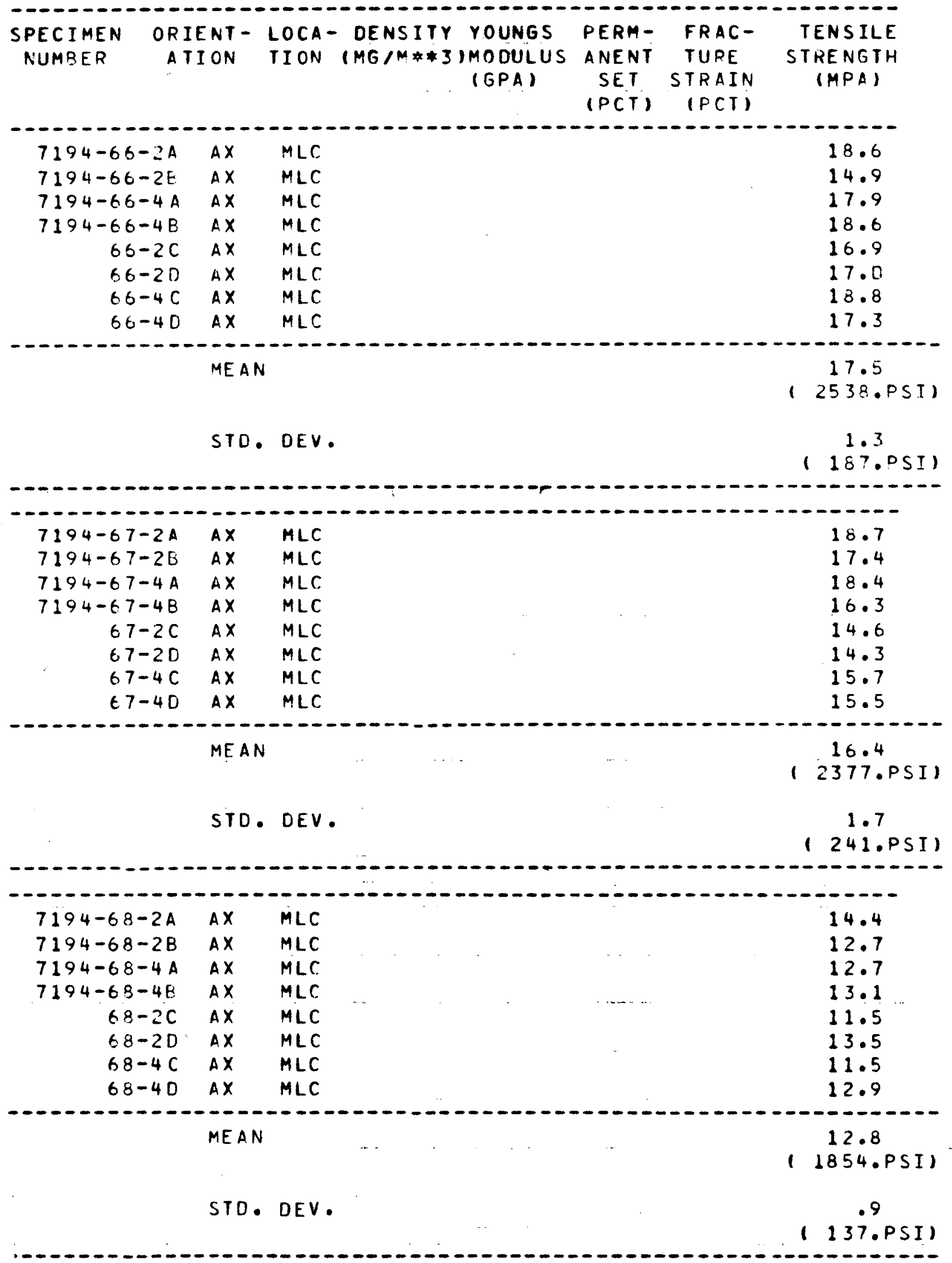


TABLE B-2 (Continued)

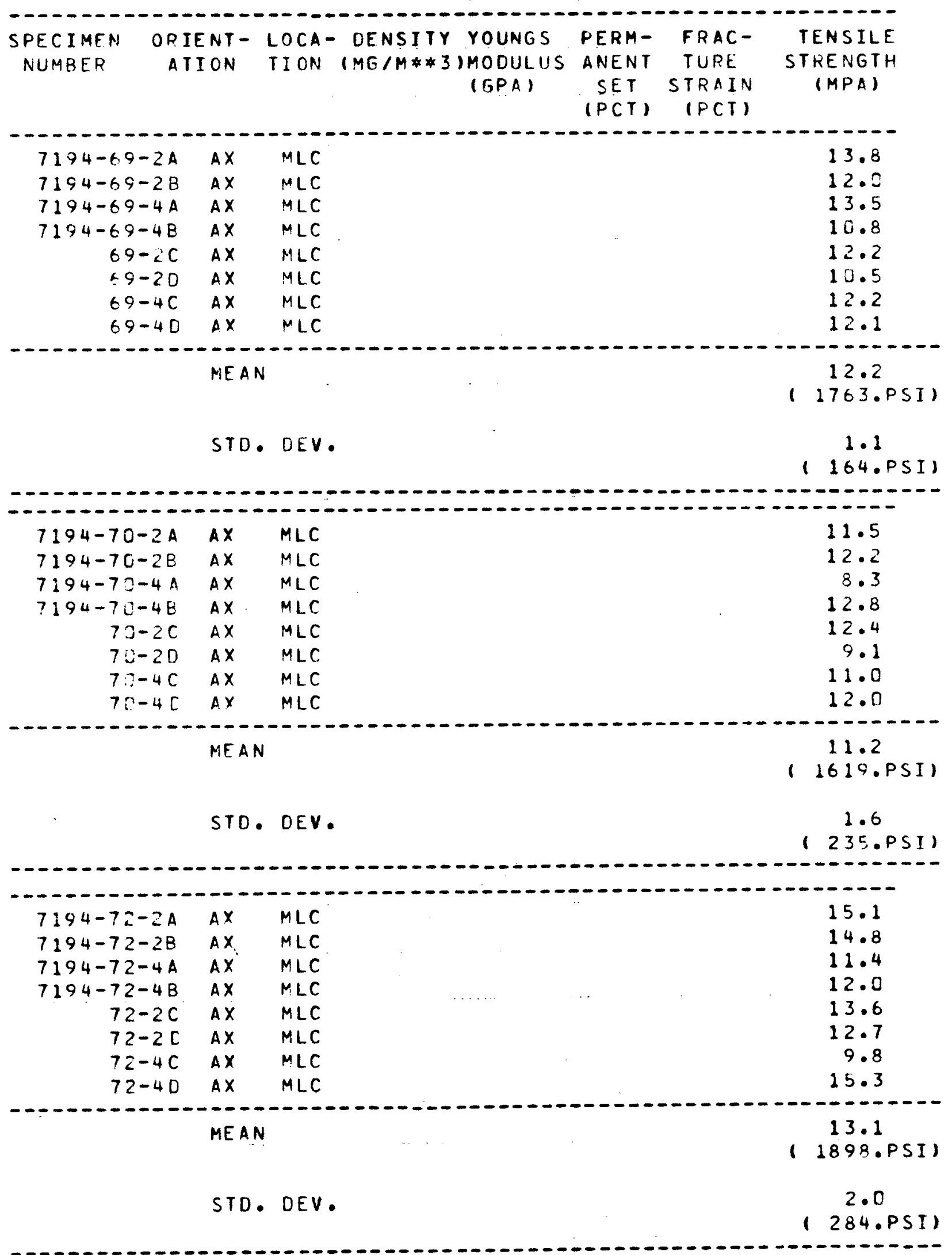


TABLE B-2 (Continued)

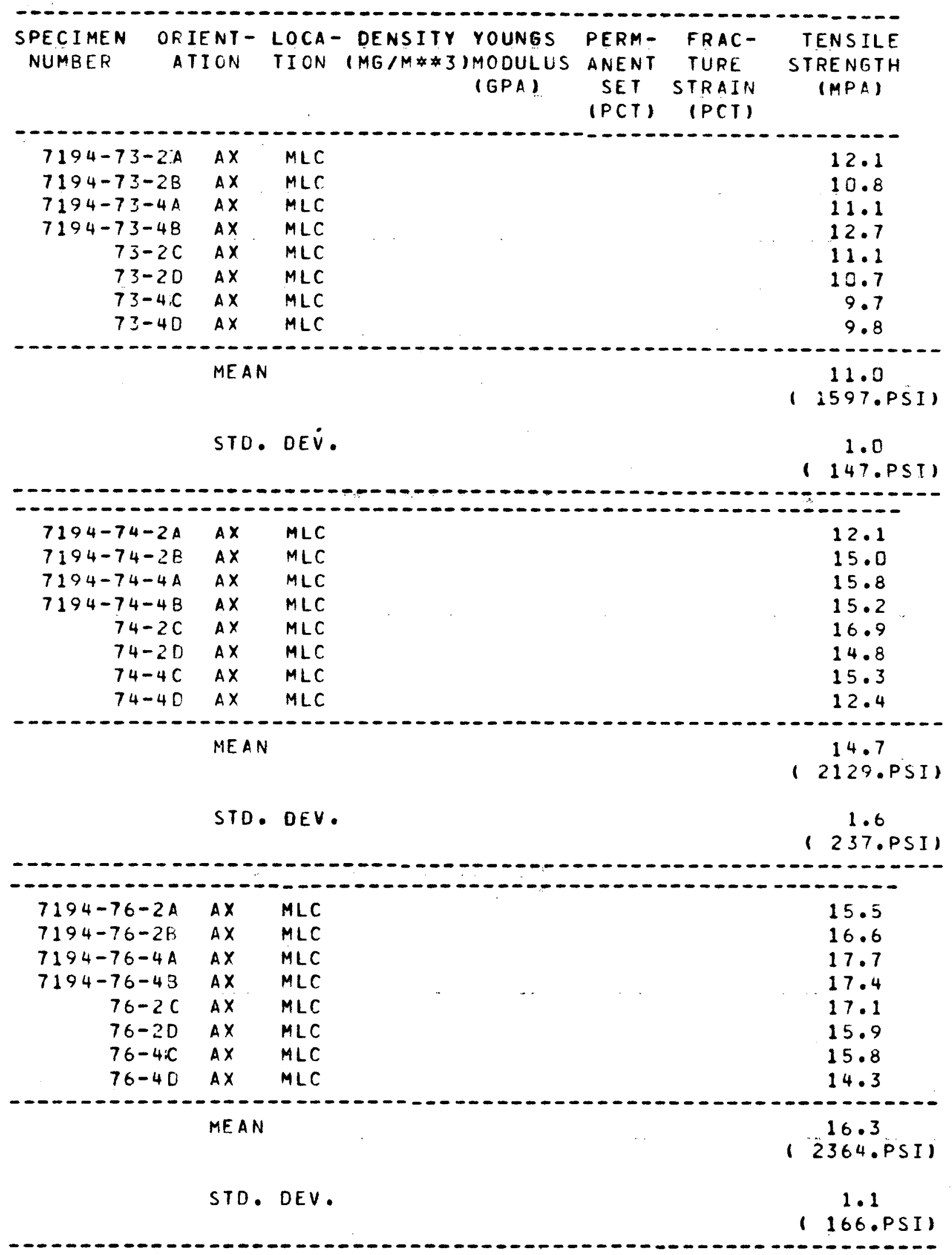




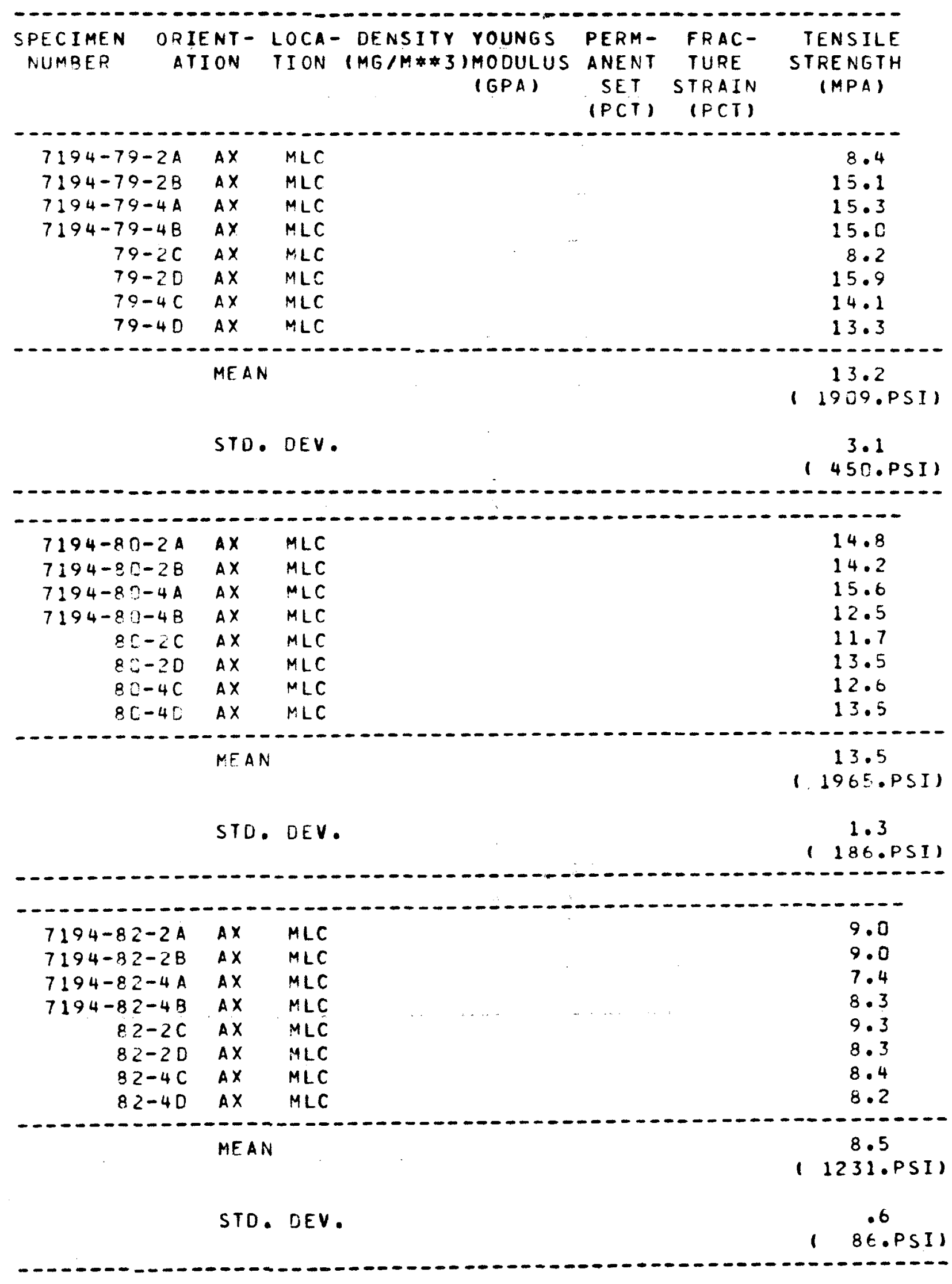


TABLE B-2 (Continued)

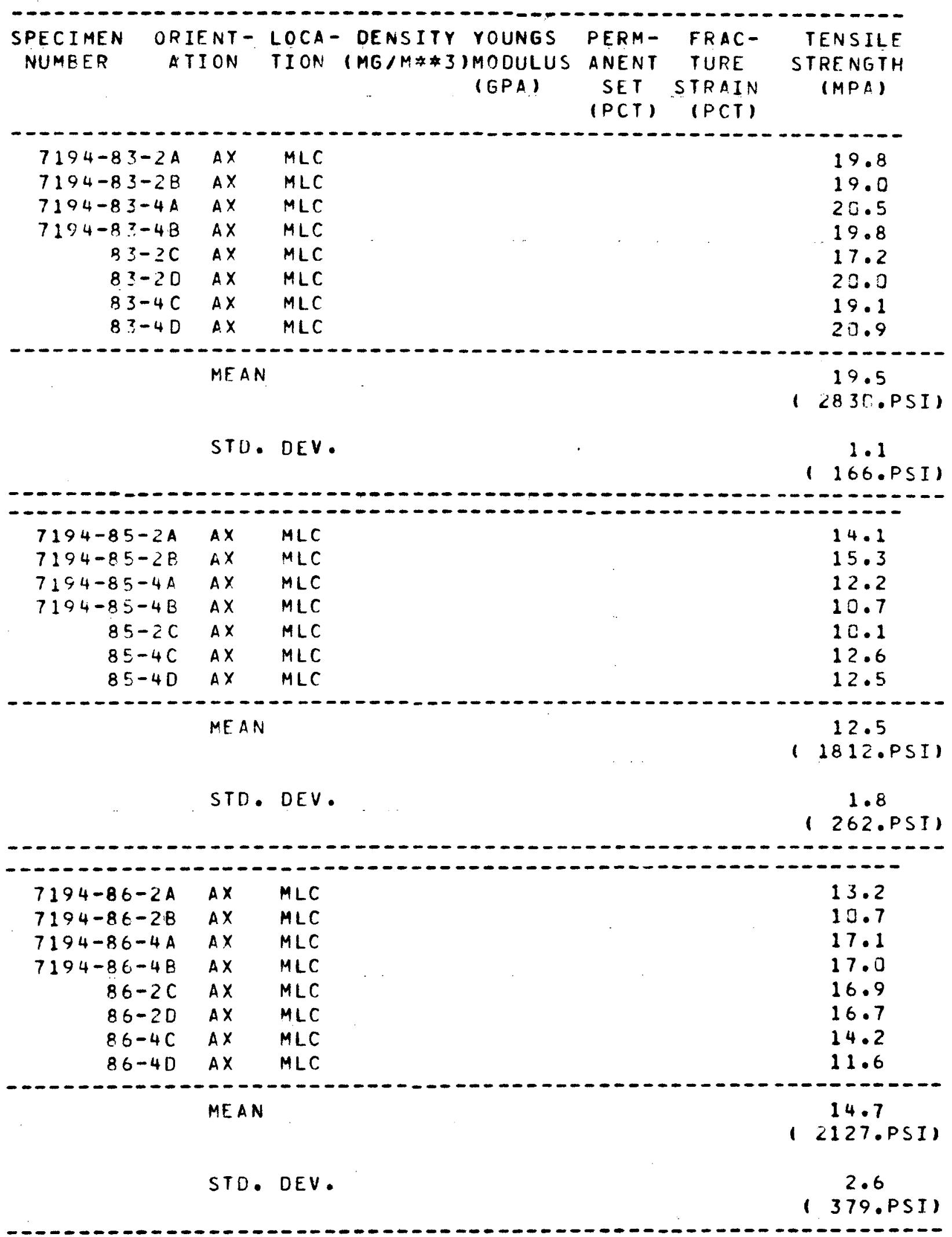


TABLE B-2 (Continued)

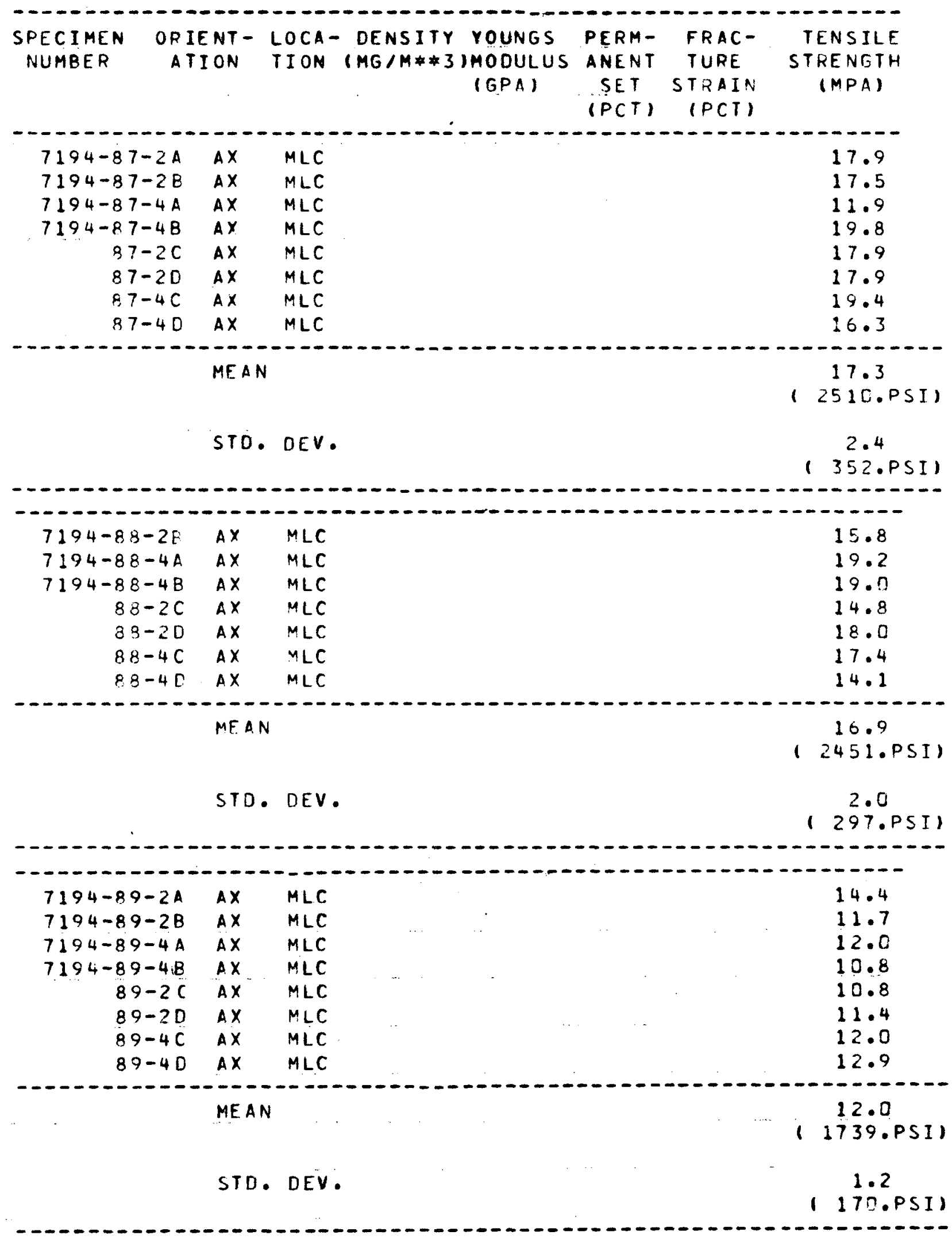


TABLE B-2 (Continued)

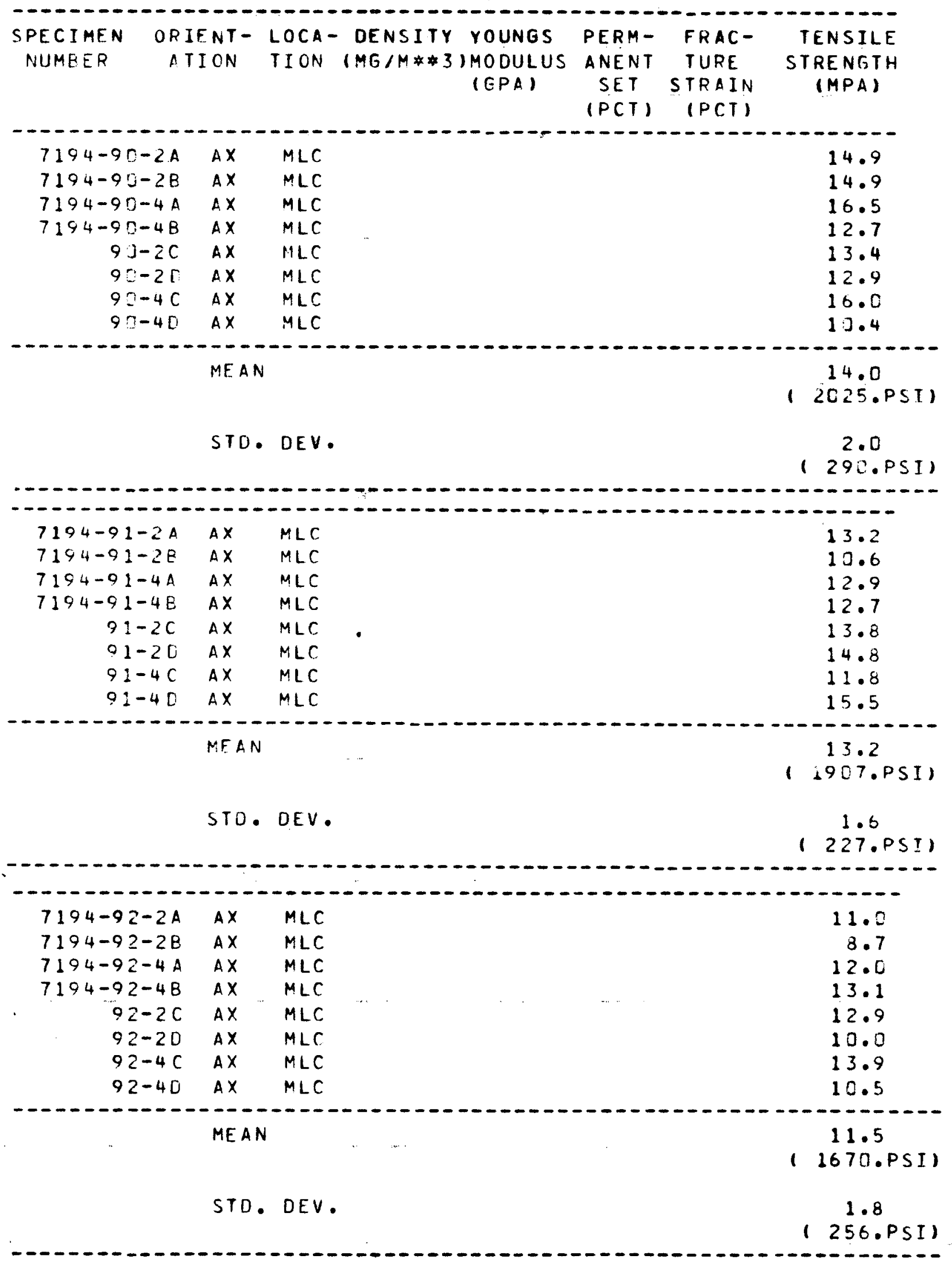


TABLE B-2 (Continued)

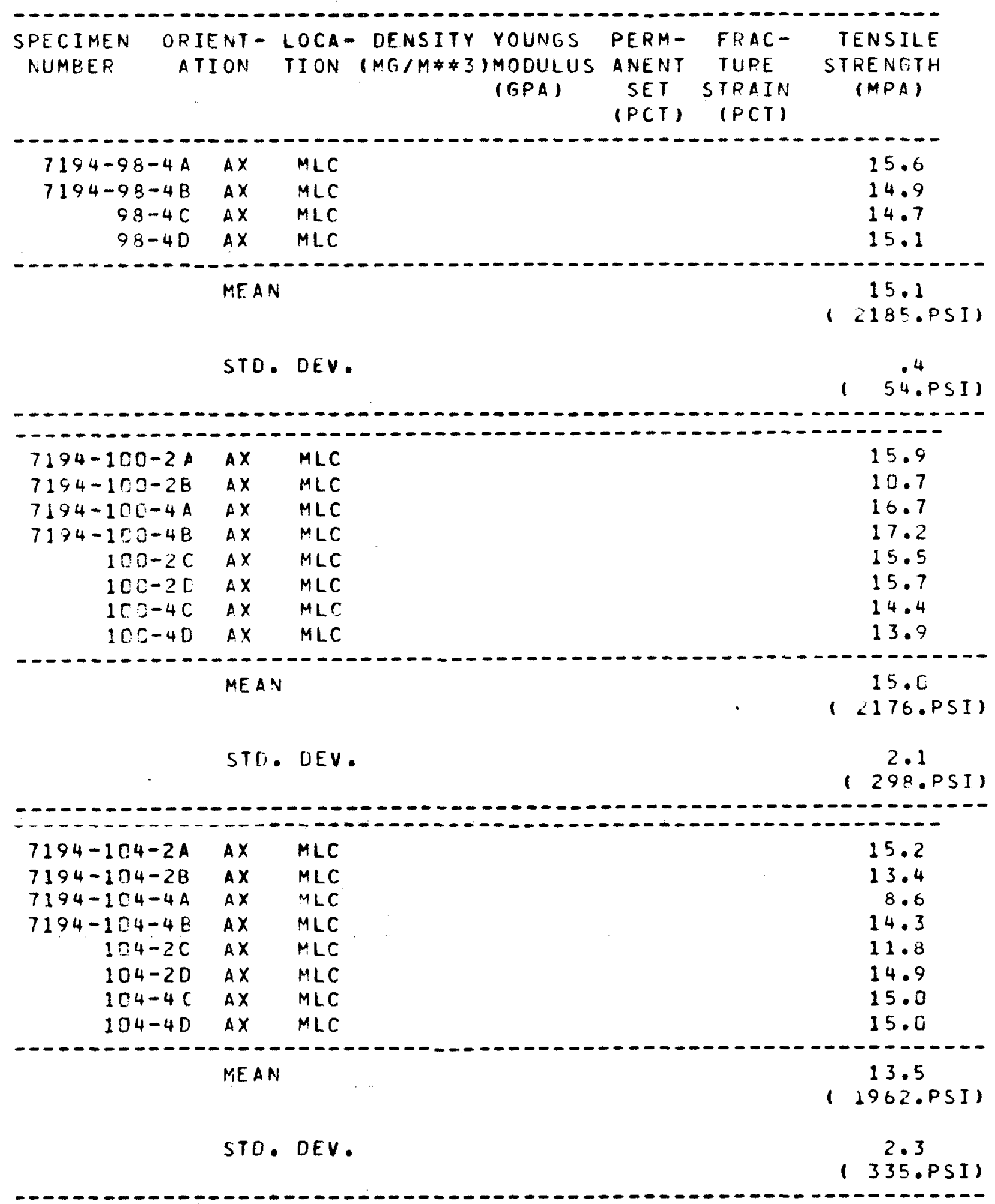


TABLE B-2 (Continued)

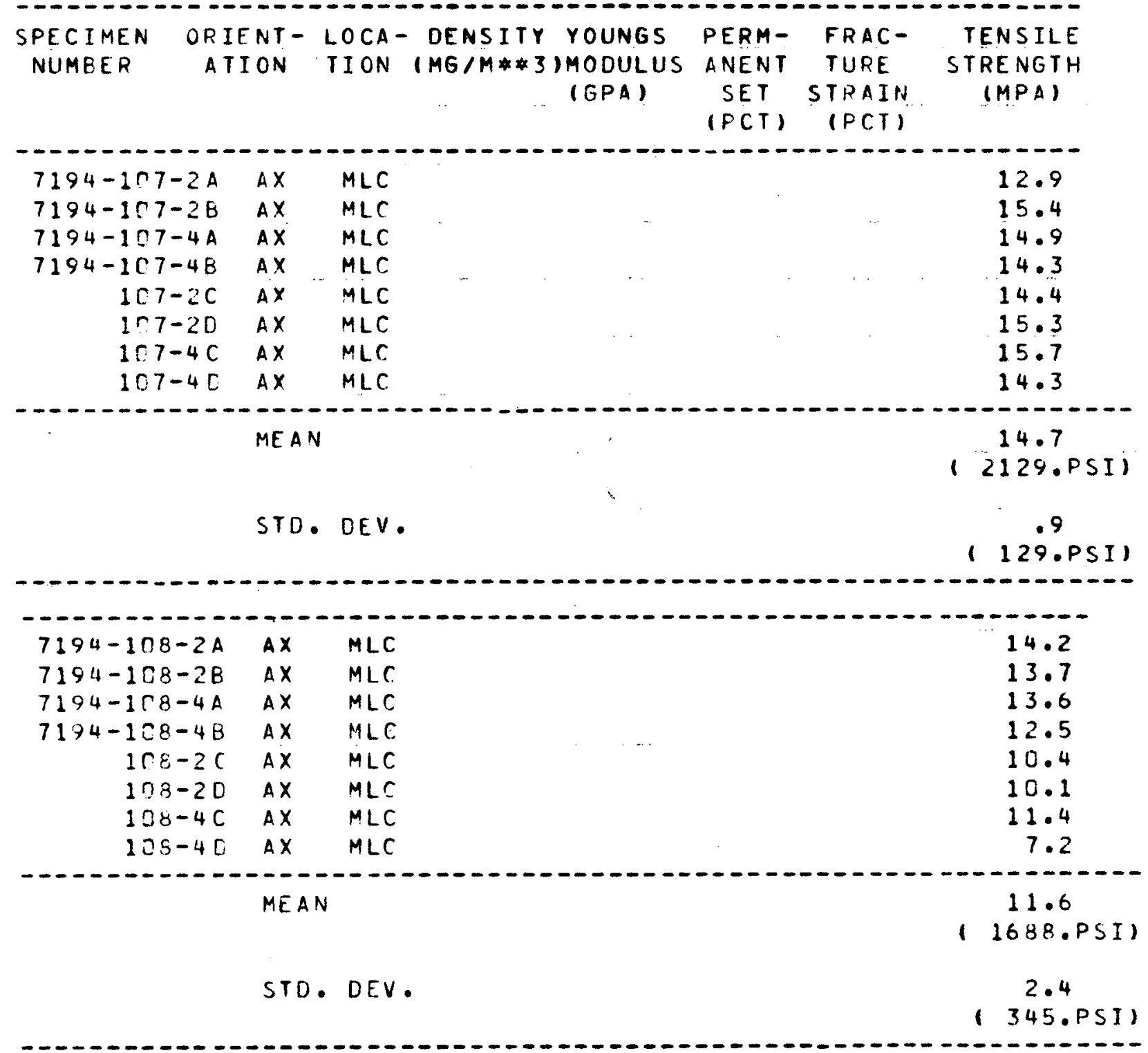


TABLE B-3

AXIAL TENSILE STRENGTH MEASUREMENTS: EXTRUSION LOT 482

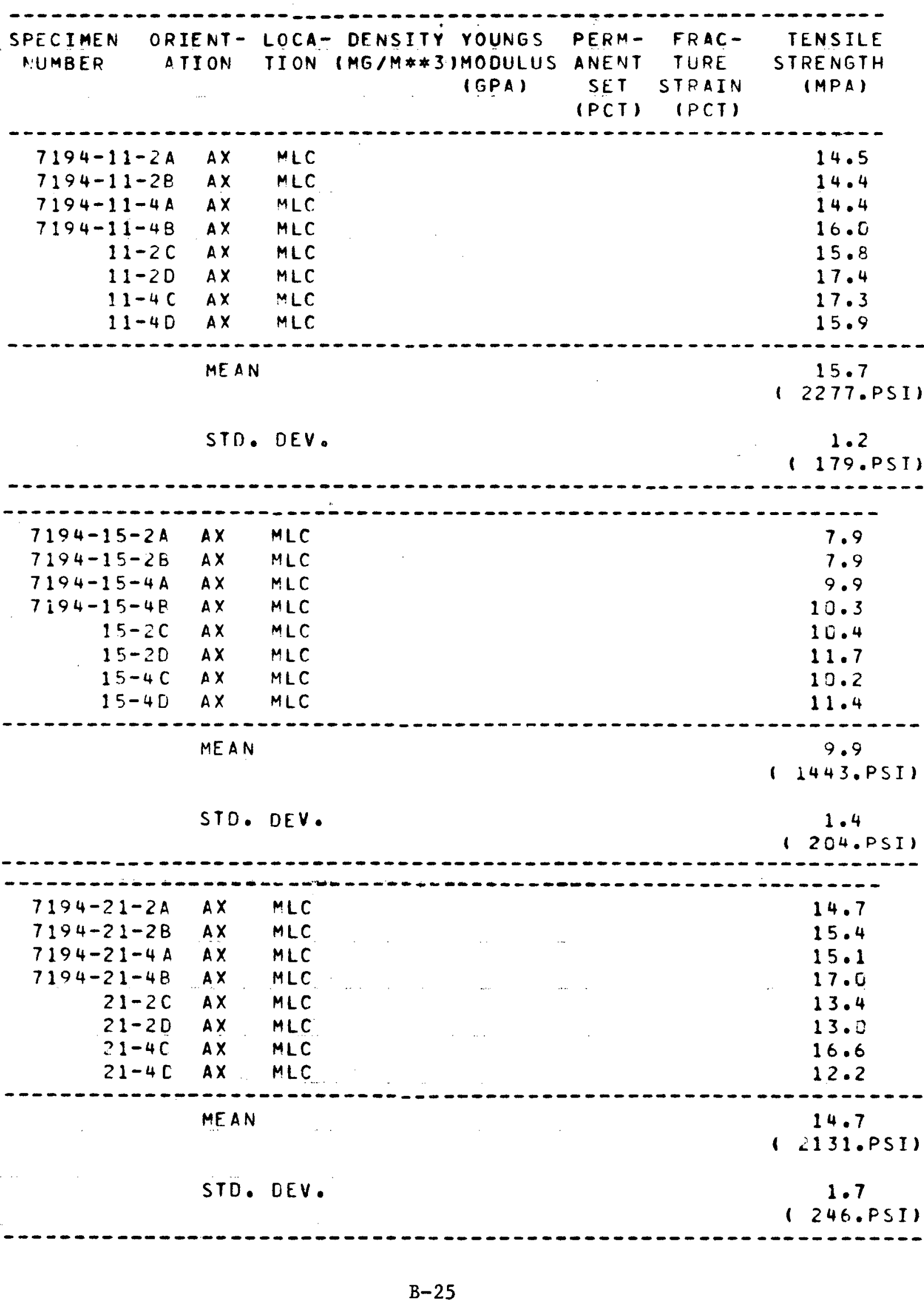




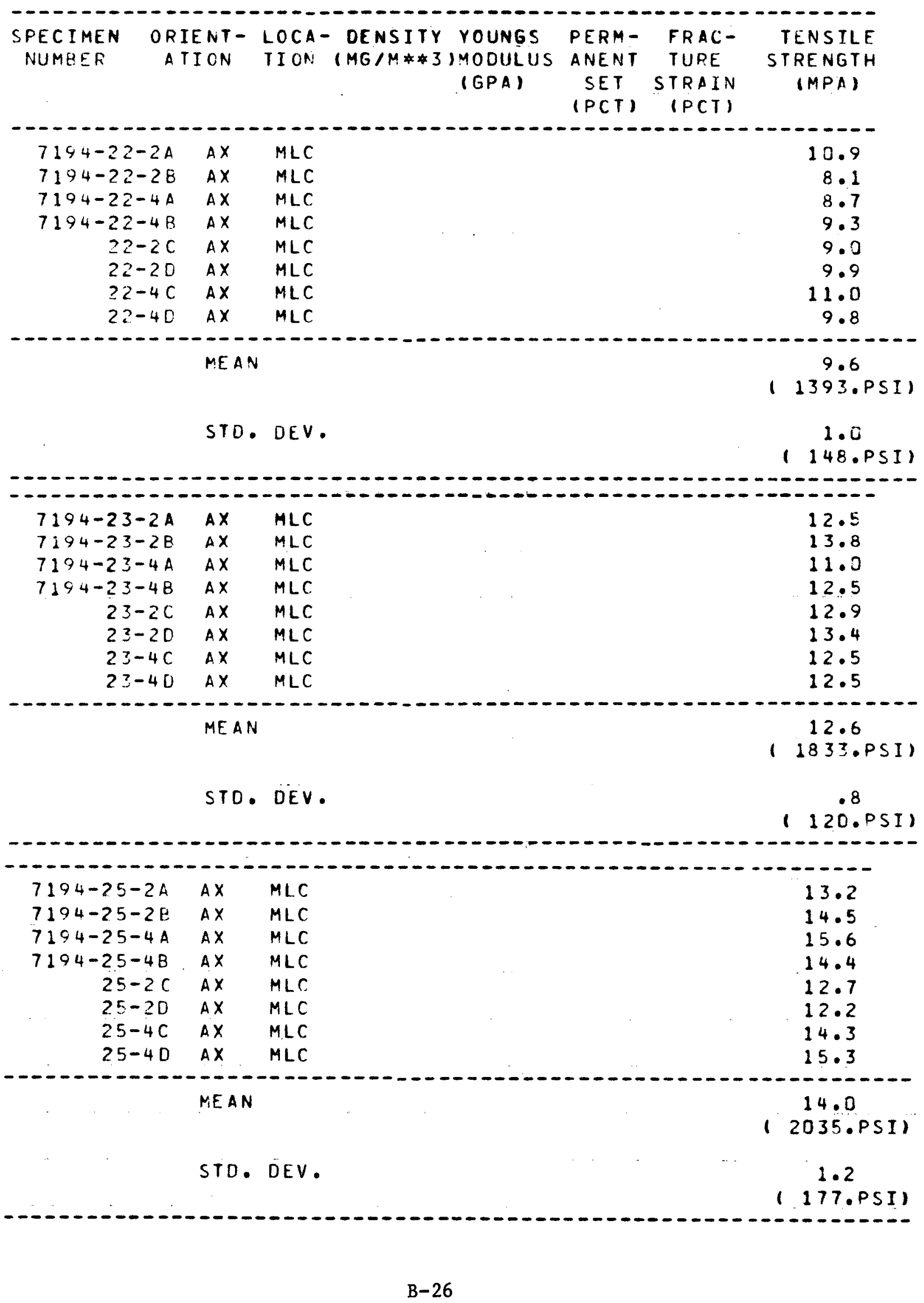




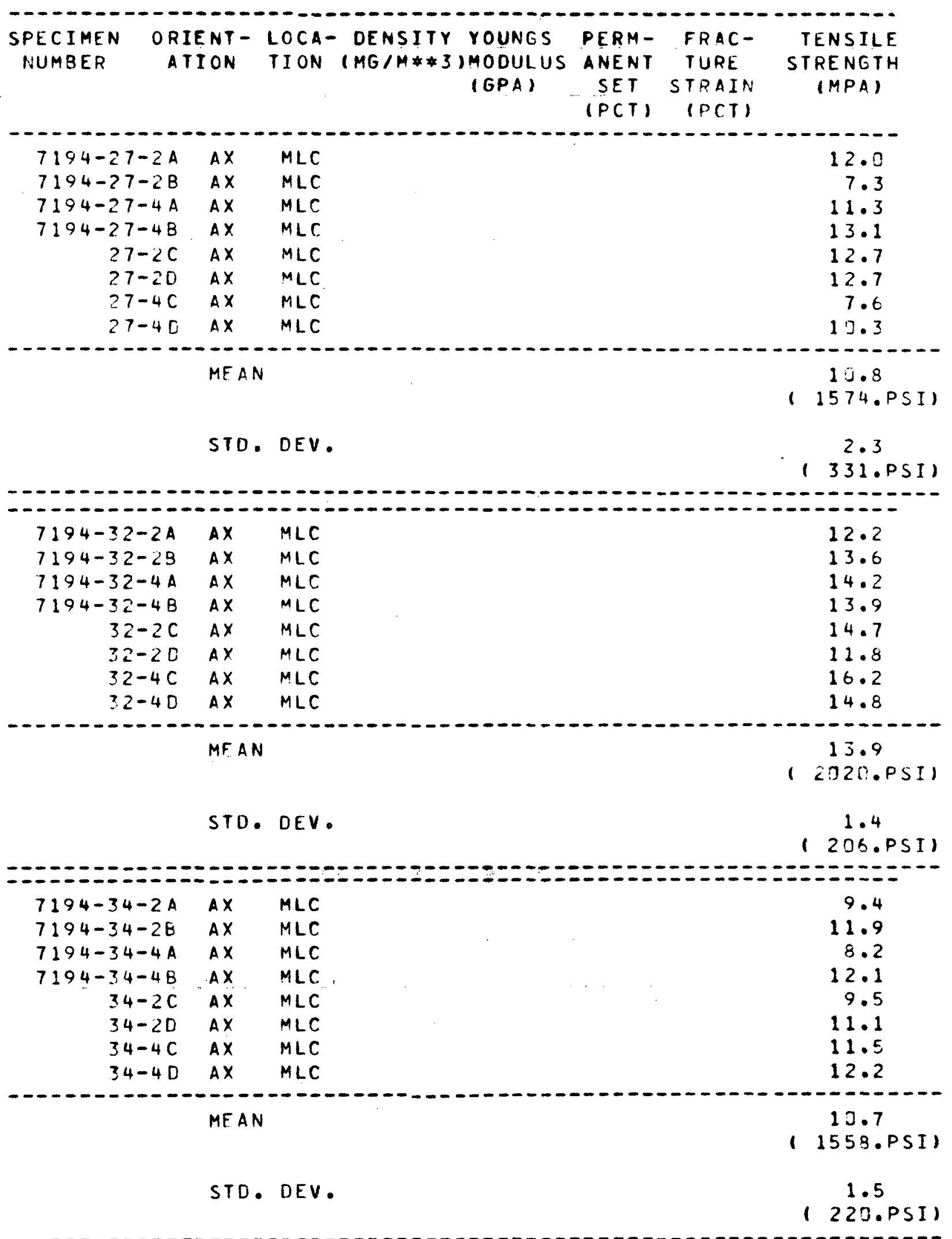




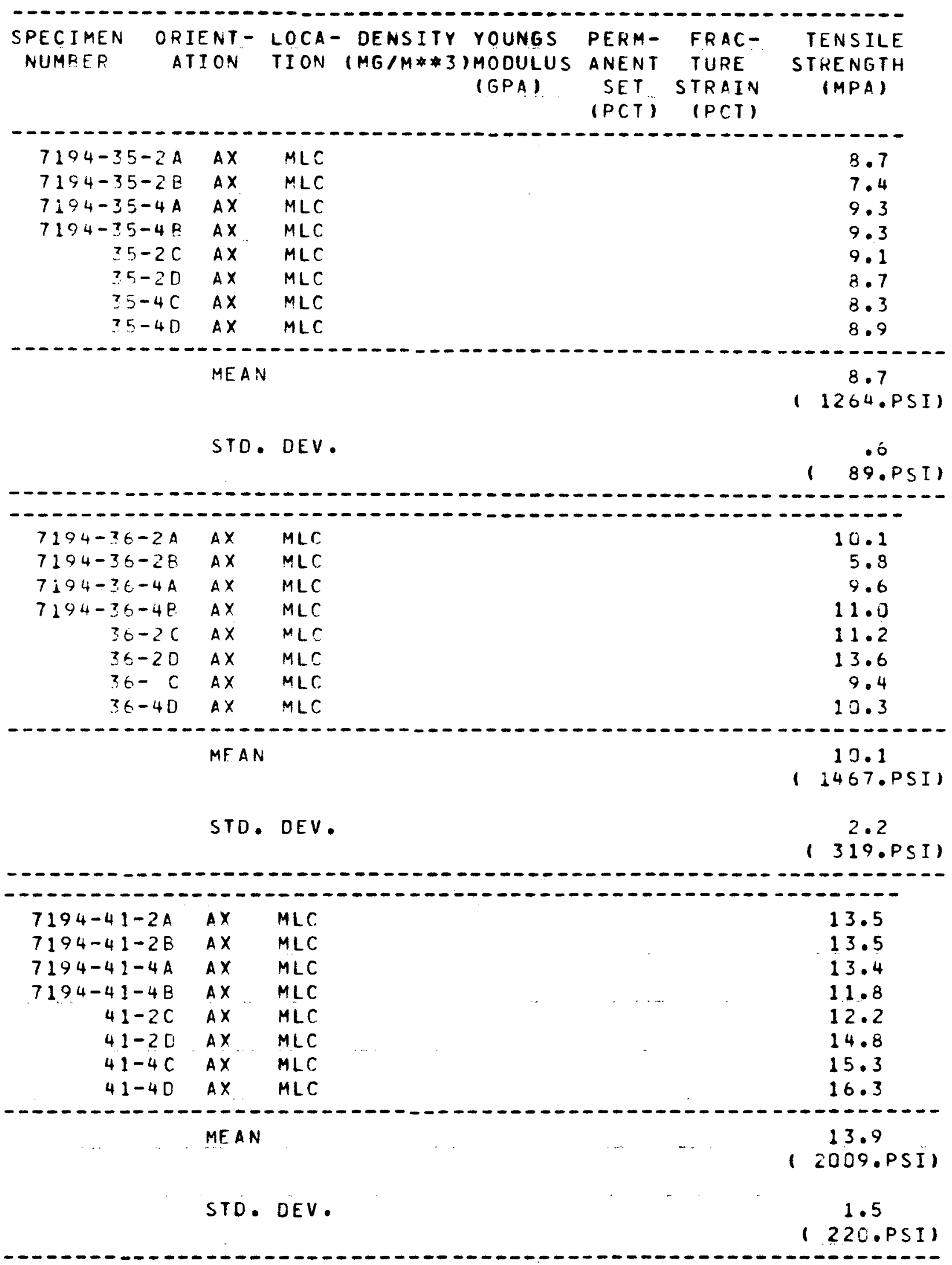


TABLE B-3 (Continued)

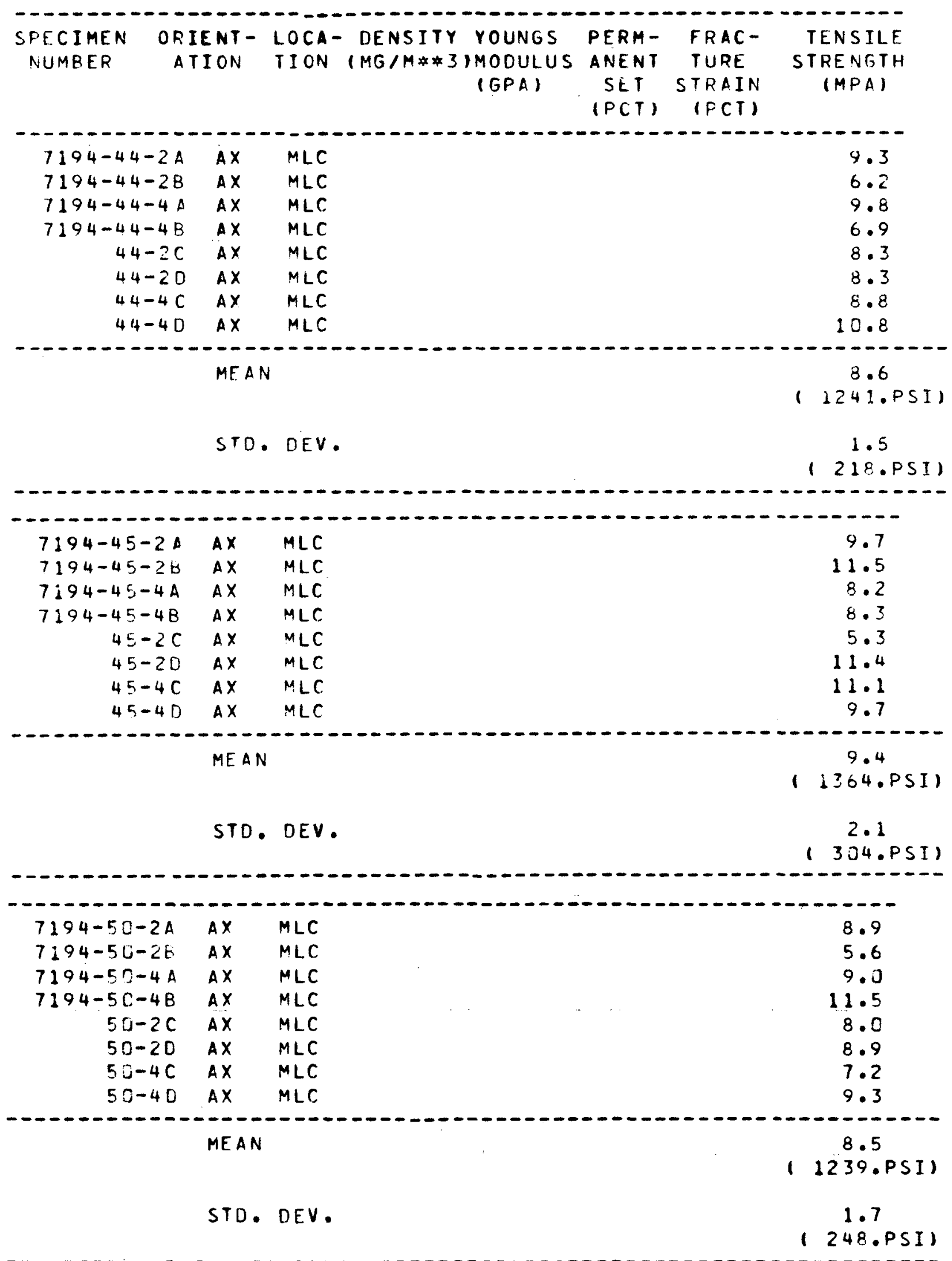


TABLE B-3 (Continued)

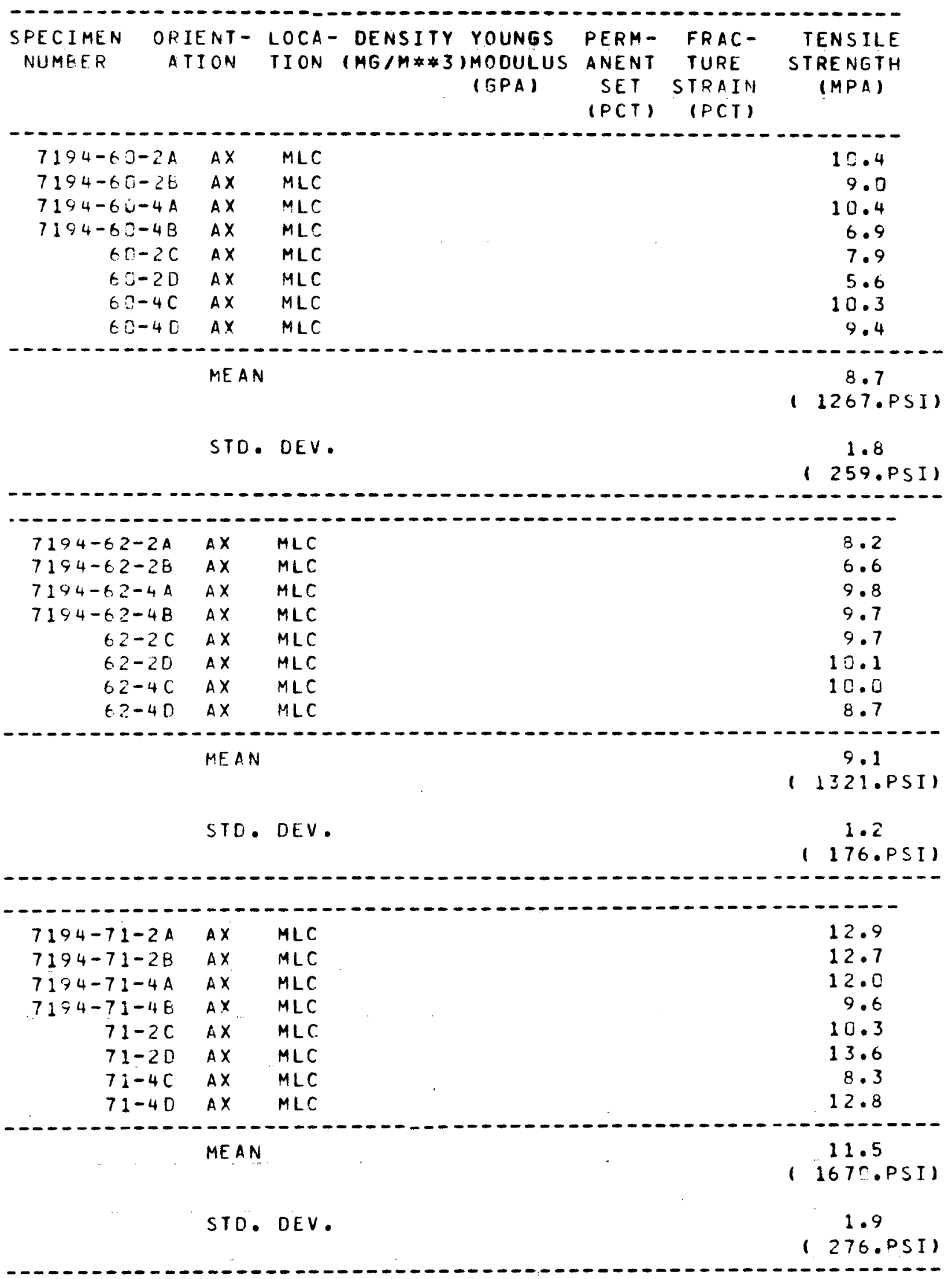


TABLE B-3 (Continued)

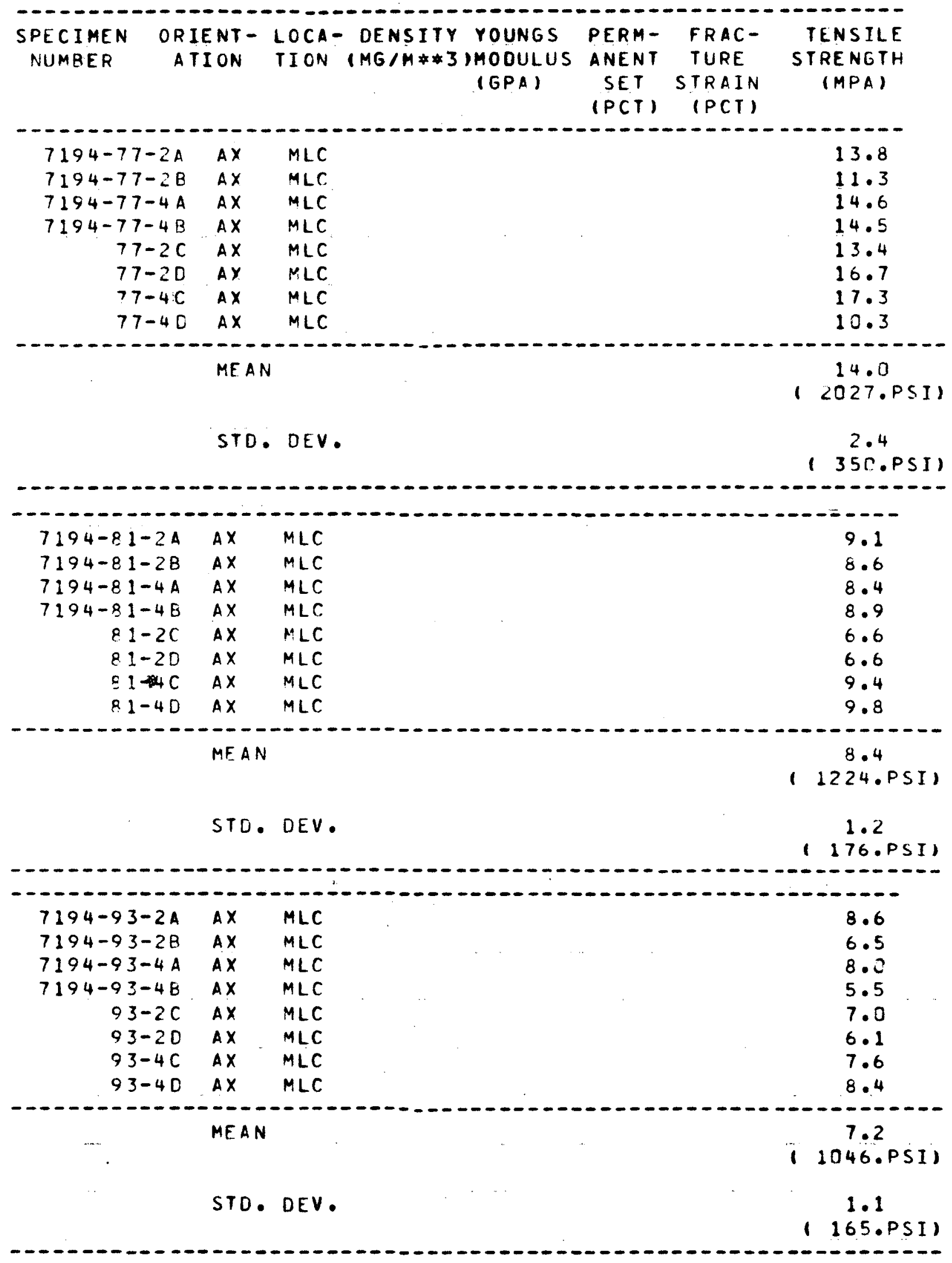


TABLE B-3 (Continued)

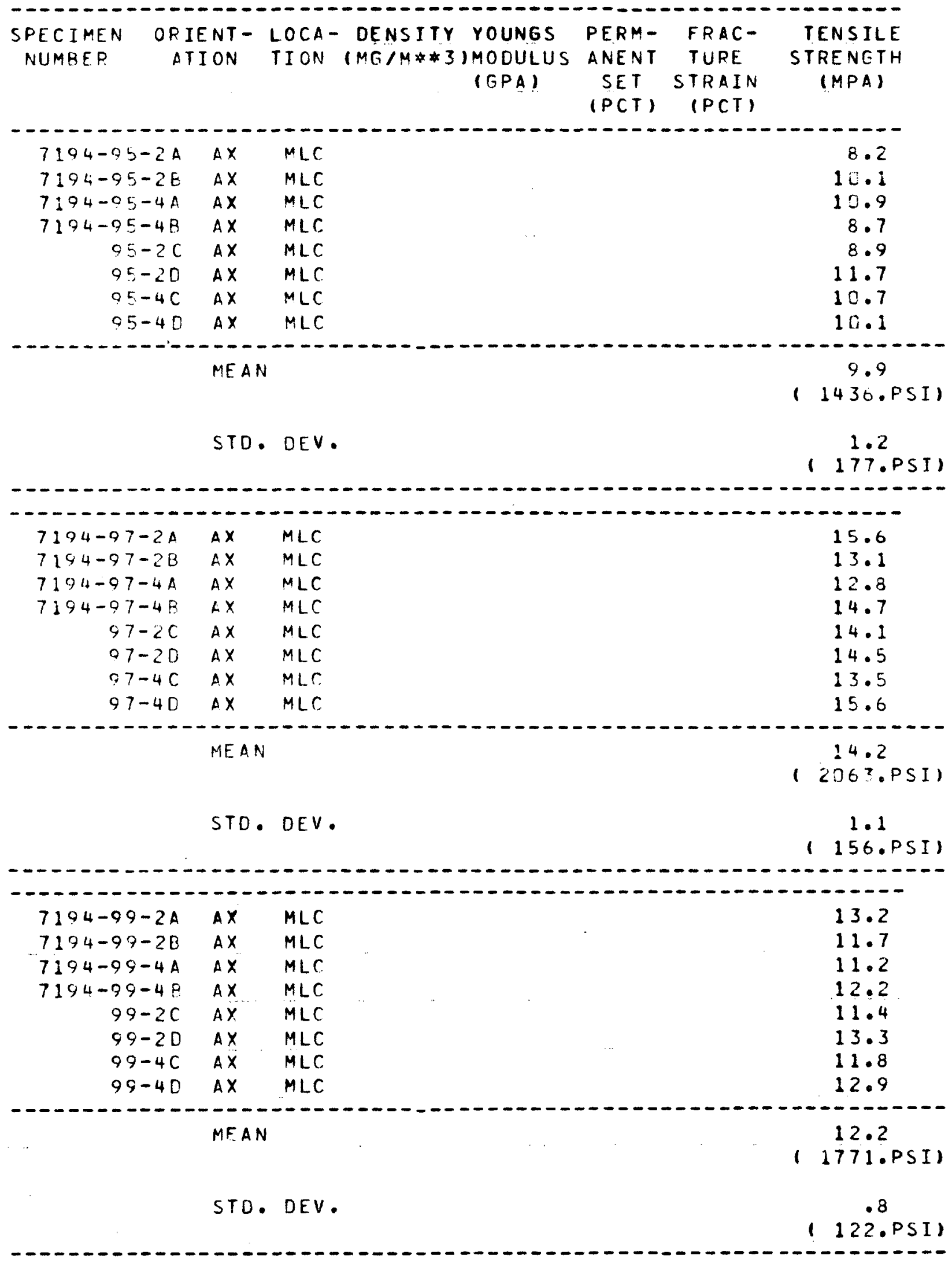


TABLE B-3 (Continued)

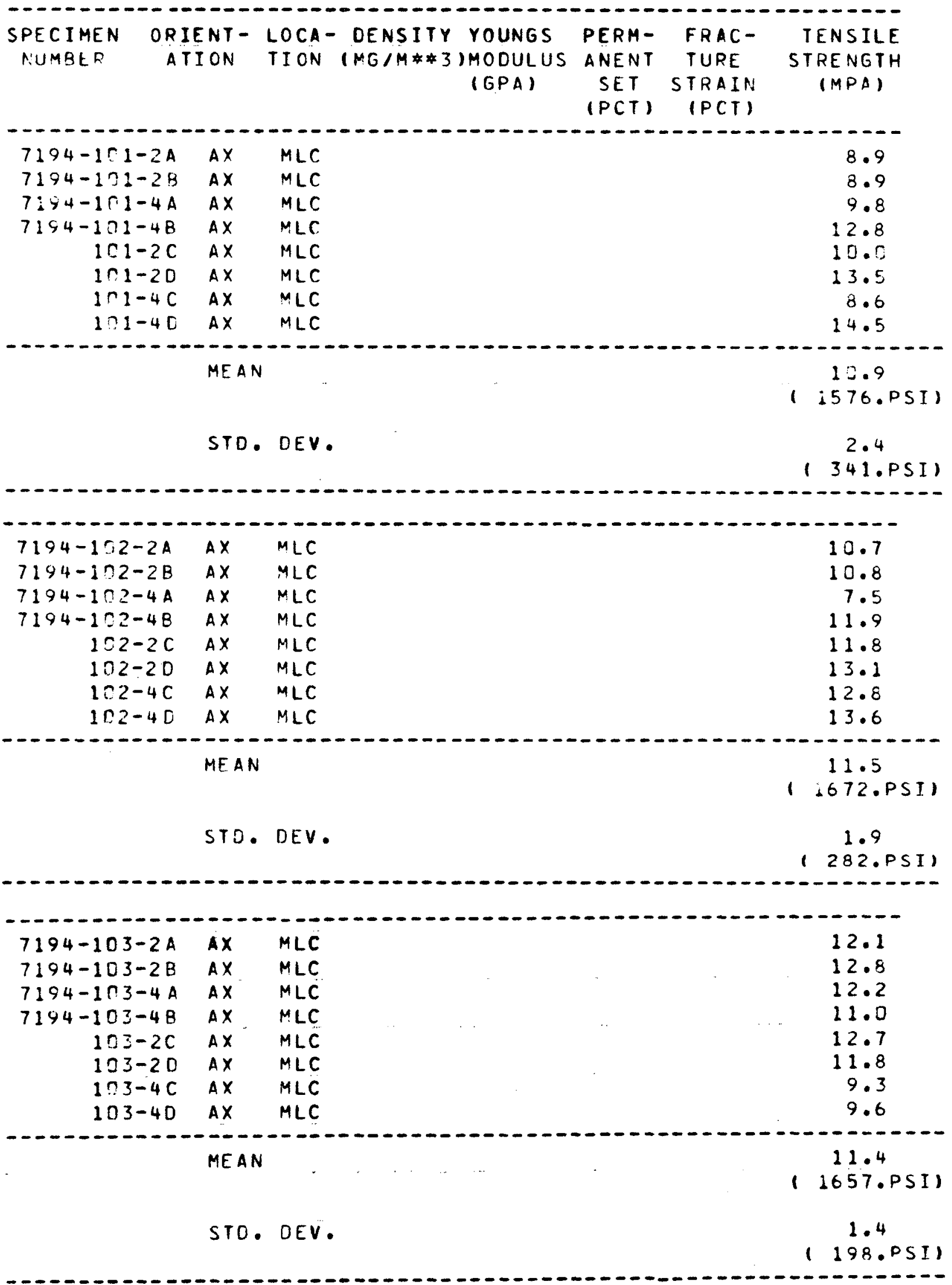


TABLE B-3 (Continued)

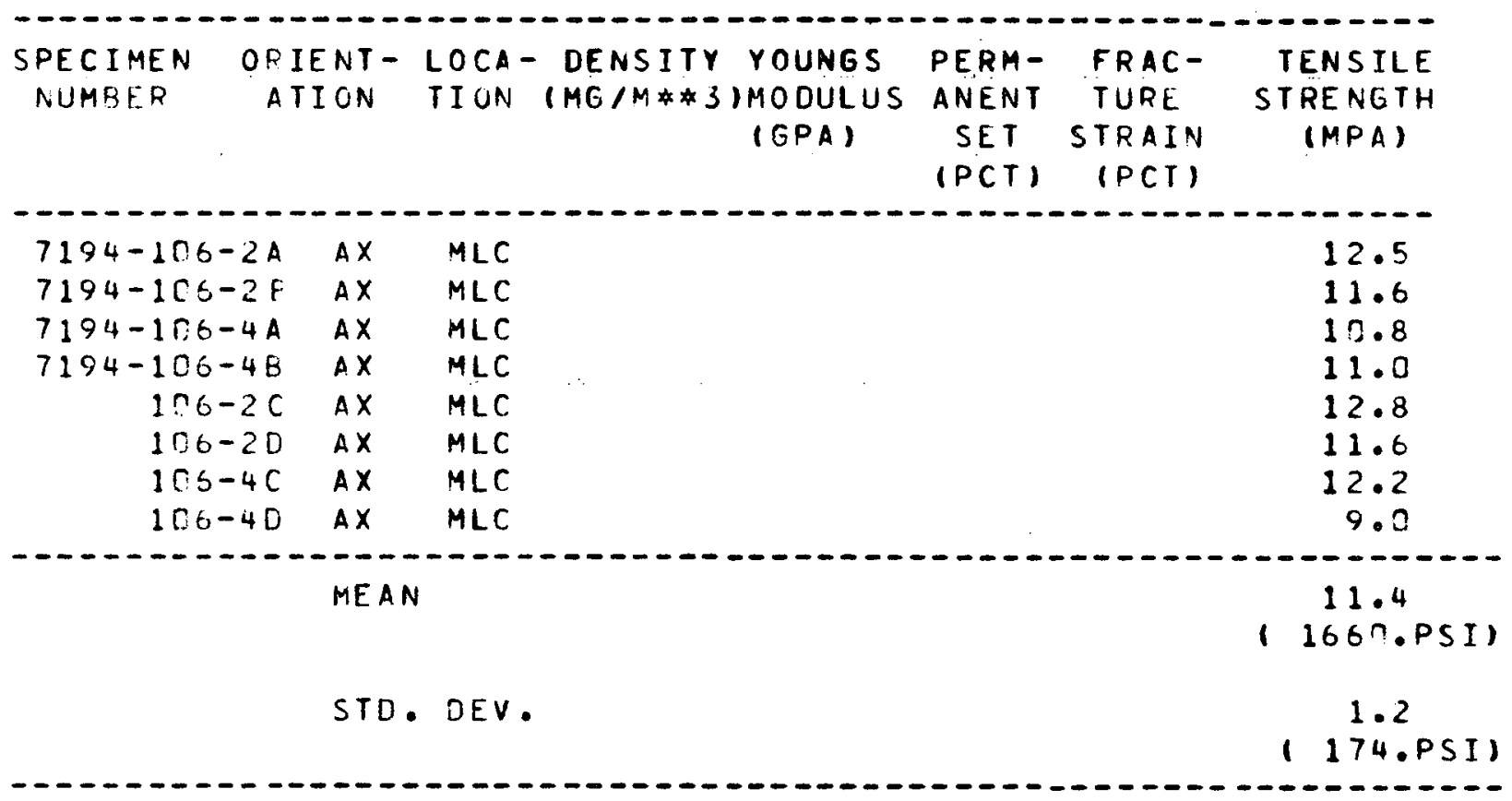


TABLE B-4

SUMMARY OF AXIAL STRENGTH DATA FOR EXTRUSION LOT 472

\begin{tabular}{|c|c|c|c|c|c|c|c|}
\hline \multirow{3}{*}{$\begin{array}{l}\text { GA Log } \\
\text { Number } \\
(7194-)\end{array}$} & \multicolumn{3}{|c|}{ Strength $(\mathrm{MPa})$} & \multicolumn{4}{|c|}{ Assigned Strength Category } \\
\hline & \multirow{2}{*}{\begin{tabular}{|c|} 
GLCC \\
1 Specimen
\end{tabular}} & \multicolumn{2}{|c|}{$G A$} & \multirow{2}{*}{$\begin{array}{c}\text { Based on } \\
90 / 90 \\
\text { Conf. (a) }\end{array}$} & \multirow{2}{*}{ 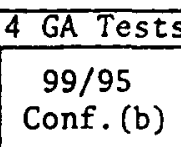 } & \multirow{2}{*}{$\begin{array}{c}\text { Based on } \\
90 / 90 \\
\text { Conf. (a) }\end{array}$} & \multirow{2}{*}{$\begin{array}{l}8 \text { GA Tests } \\
99 / 95 \\
\text { Conf. (b) }\end{array}$} \\
\hline & & $\begin{array}{l}\text { Mean of } 4 \\
\text { (AGB Specs.) }\end{array}$ & $\begin{array}{l}\text { Mean of } 8 \\
\text { Specimens }\end{array}$ & & & & \\
\hline 16 & 12.8 & 13.6 & 14.2 & A & B & A & B \\
\hline 20 & 15.4 & 15.3 & 15.2 & A & B & A & A \\
\hline 26 & 14.8 & 12.4 & 12.4 & B & $\mathrm{C}$ & B & C \\
\hline 29 & 10.0 & 9.6 & 10.3 & $\mathrm{C}$ & Reject & C & $\mathrm{C}$ \\
\hline 40 & 12.6 & 7.1 & 7.0 & Reject & Reject & Reject & Reject \\
\hline 42 & 11.4 & 10.2 & 10.1 & C & Reject & $C$ & Reject \\
\hline 46 & 17.0 & 14.8 & 14.1 & A & B & A & B \\
\hline 55 & 8.8 & 15.2 & 15.2 & A & B & A & A \\
\hline 75 & 14.3 & 15.8 & 14.8 & A & A & A & B. \\
\hline 78 & 13.1 & 10.2 & 10.1 & $\mathrm{C}$ & Reject & $\mathrm{C}$ & Reject \\
\hline 84 & 12.2 & 14.9 & 14.8 & A & B & A & B \\
\hline 94 & 12.1 & 12.6 & 12.3 & B & $\mathrm{C}$ & B & $C$ \\
\hline 96 & 13.4 & 8.9 & 8.8 & $\mathrm{C}$ & Reject & $\mathrm{C}$ & Reject \\
\hline 105 & 14.7 & 13.0 & 12.6 & $B$ & $\mathrm{C}$ & B & $\mathrm{C}$ \\
\hline
\end{tabular}

(a) At least $90 \%$ of material at midlength-center exceeds specified minimum strength, with $90 \%$ confidence.

(b) At least $99 \%$ of material at midlength-center exceeds specified minimum strength, with $95 \%$ confidence. 
TABLE B-5

SUMMARY OF AXIAL STRENGTH DATA FOR EXTRUSION LOT 478

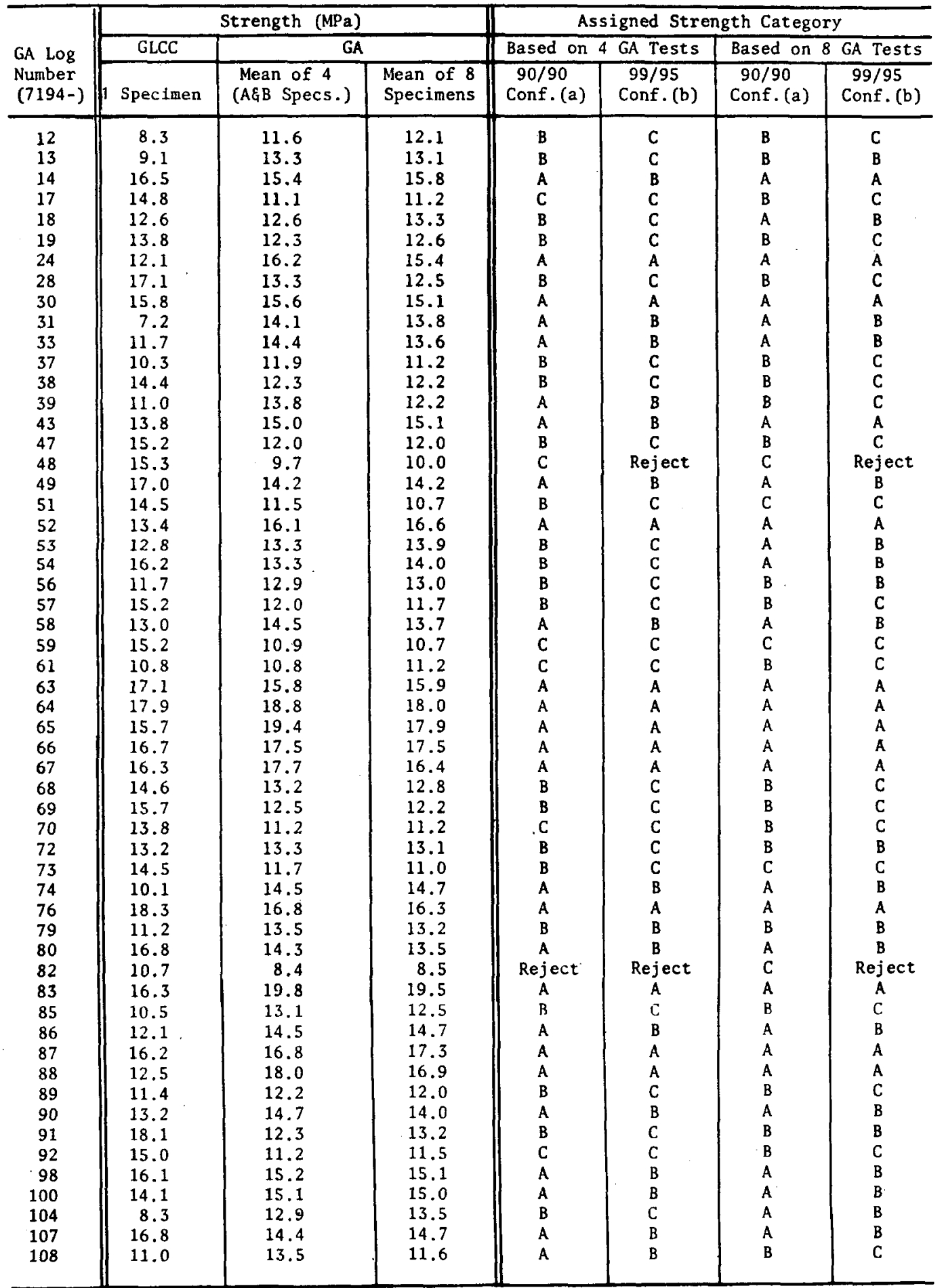

(a) At least $90 \%$ of material at midlength center exceeds specified minimum strength, with $90 \%$ confidence.

(b) At least $99 \%$ of material at midlength center exceeds specified minimum strength, with $95 \%$ confidence. 
TABLE B-6

SUMMARY OF AXIAL STRENGTH DATA FOR EXTRUSION LOT 482

\begin{tabular}{|c|c|c|c|c|c|c|c|}
\hline \multirow{3}{*}{$\begin{array}{l}\text { GA Log } \\
\text { Number } \\
(7194-)\end{array}$} & \multicolumn{3}{|c|}{ Strength $(\mathrm{MPa})$} & \multicolumn{4}{|c|}{ Assigned Strength Category } \\
\hline & \multirow{2}{*}{$\frac{\text { GLCC }}{1 \text { Specimen }}$} & \multicolumn{2}{|c|}{ GA } & \multicolumn{2}{|c|}{ Based on $4 \mathrm{GA}$ Tests } & \multicolumn{2}{|c|}{ Based on 8 GA Tests } \\
\hline & & $\begin{array}{c}\text { Mean of } 4 \\
\text { (A/B Specs.) }\end{array}$ & $\begin{array}{l}\text { Mean of } 8 \\
\text { Specimens }\end{array}$ & $\begin{array}{c}90 / 90 \\
\text { Conf. (a) }\end{array}$ & $\begin{array}{c}99 / 95 \\
\text { Conf. (b) }\end{array}$ & $\begin{array}{c}90 / 90 \\
\text { Conf. (a) }\end{array}$ & $\begin{array}{c}99 / 95 \\
\text { Conf. (b) }\end{array}$ \\
\hline $\begin{array}{r}11 \\
15 \\
21 \\
22 \\
23 \\
25 \\
27 \\
32 \\
34 \\
35 \\
36 \\
41 \\
44 \\
45 \\
50 \\
60 \\
62 \\
71 \\
77 \\
81 \\
93 \\
95 \\
97 \\
99 \\
101 \\
102 \\
103 \\
106\end{array}$ & $\begin{array}{r}19.0 \\
8.8 \\
13.6 \\
9.7 \\
14.2 \\
18.9 \\
8.7 \\
17.9 \\
11.1 \\
9.8 \\
16.2 \\
16.2 \\
7.9 \\
11.9 \\
9.7 \\
7.0 \\
7.2 \\
16.6 \\
15.4 \\
7.9 \\
6.3 \\
16.0 \\
16.2 \\
16.7 \\
14.9 \\
16.2 \\
7.7 \\
10.7\end{array}$ & $\begin{array}{r}14.8 \\
9.0 \\
15.6 \\
9.3 \\
12.5 \\
14.4 \\
10.9 \\
13.5 \\
10.4 \\
8.7 \\
9.1 \\
13.1 \\
8.1 \\
9.4 \\
8.8 \\
9.2 \\
8.6 \\
11.8 \\
13.5 \\
8.8 \\
7.1 \\
9.5 \\
14.0 \\
12.1 \\
10.1 \\
10.2 \\
12.0 \\
11.5\end{array}$ & $\begin{array}{r}15.7 \\
9.9 \\
14.7 \\
9.6 \\
12.6 \\
14.0 \\
10.8 \\
13.9 \\
10.7 \\
8.7 \\
10.1 \\
13.9 \\
8.6 \\
9.4 \\
8.5 \\
8.7 \\
9.1 \\
11.5 \\
14.0 \\
8.4 \\
7.2 \\
9.9 \\
14.2 \\
12.2 \\
10.9 \\
11.5 \\
11.4 \\
11.4\end{array}$ & $\begin{array}{c}\text { A } \\
\text { C } \\
\text { A } \\
\text { C } \\
\text { B } \\
\text { A } \\
C \\
\text { A } \\
C \\
C \\
C \\
\text { B } \\
\text { Reject } \\
\text { C } \\
\text { C } \\
\text { C } \\
\text { Reject } \\
\text { B } \\
\text { A } \\
\text { C } \\
\text { Reject } \\
\text { C } \\
\text { A } \\
\text { B } \\
\text { C } \\
\text { C } \\
\text { B } \\
\text { B }\end{array}$ & $\begin{array}{c}\text { B } \\
\text { Reject } \\
\text { A } \\
\text { Reject } \\
C \\
B \\
C \\
B \\
\text { Reject } \\
\text { Reject } \\
\text { Reject } \\
\text { C } \\
\text { Reject } \\
\text { Reject } \\
\text { Reject } \\
\text { Reject } \\
\text { Reject } \\
C \\
\text { B } \\
\text { Reject } \\
\text { Reject } \\
\text { Reject } \\
\text { B } \\
\text { C } \\
\text { Reject } \\
\text { Reject } \\
C \\
C\end{array}$ & $\begin{array}{c}\text { A } \\
\text { C } \\
\text { A } \\
\text { C } \\
\text { B } \\
\text { A } \\
\text { C } \\
\text { A } \\
\text { C } \\
\text { C } \\
\text { C } \\
\text { A } \\
\text { C } \\
\text { C } \\
\text { C } \\
\text { C } \\
\text { C } \\
\text { B } \\
\text { A } \\
\text { C } \\
\text { Reject } \\
\text { C } \\
\text { A } \\
\text { B } \\
\text { C } \\
\text { B } \\
\text { B } \\
\text { B }\end{array}$ & $\begin{array}{c}\text { A } \\
\text { Reject } \\
B \\
\text { Reject } \\
C \\
B \\
C \\
B \\
C \\
\text { Reject } \\
\text { Reject } \\
B \\
\text { Reject } \\
\text { Reject } \\
\operatorname{Reject} \\
\operatorname{Reject} \\
\operatorname{Reject} \\
C \\
B \\
\text { Reject } \\
\operatorname{Reject} \\
\operatorname{Reject} \\
B \\
C \\
C \\
C \\
C \\
C\end{array}$ \\
\hline
\end{tabular}

(a) At least $90 \%$ of material at midlength-center exceeds specified minimum strength, with $90 \%$ confidence.

(b) At least $99 \%$ of material at midlength-center exceeds specified minimum strength, with $95 \%$ confidence. 
APPENDIX C

RADIAL TENSILE STRENGTH MEASUREMENTS FOR EXTRUSION LOTS, 472, 478, AND 482 
TABLE $\mathrm{C}-1$

RADIAL TENSILE STRENGTH MEASUREMENTS: EXTRUSION LOT 472

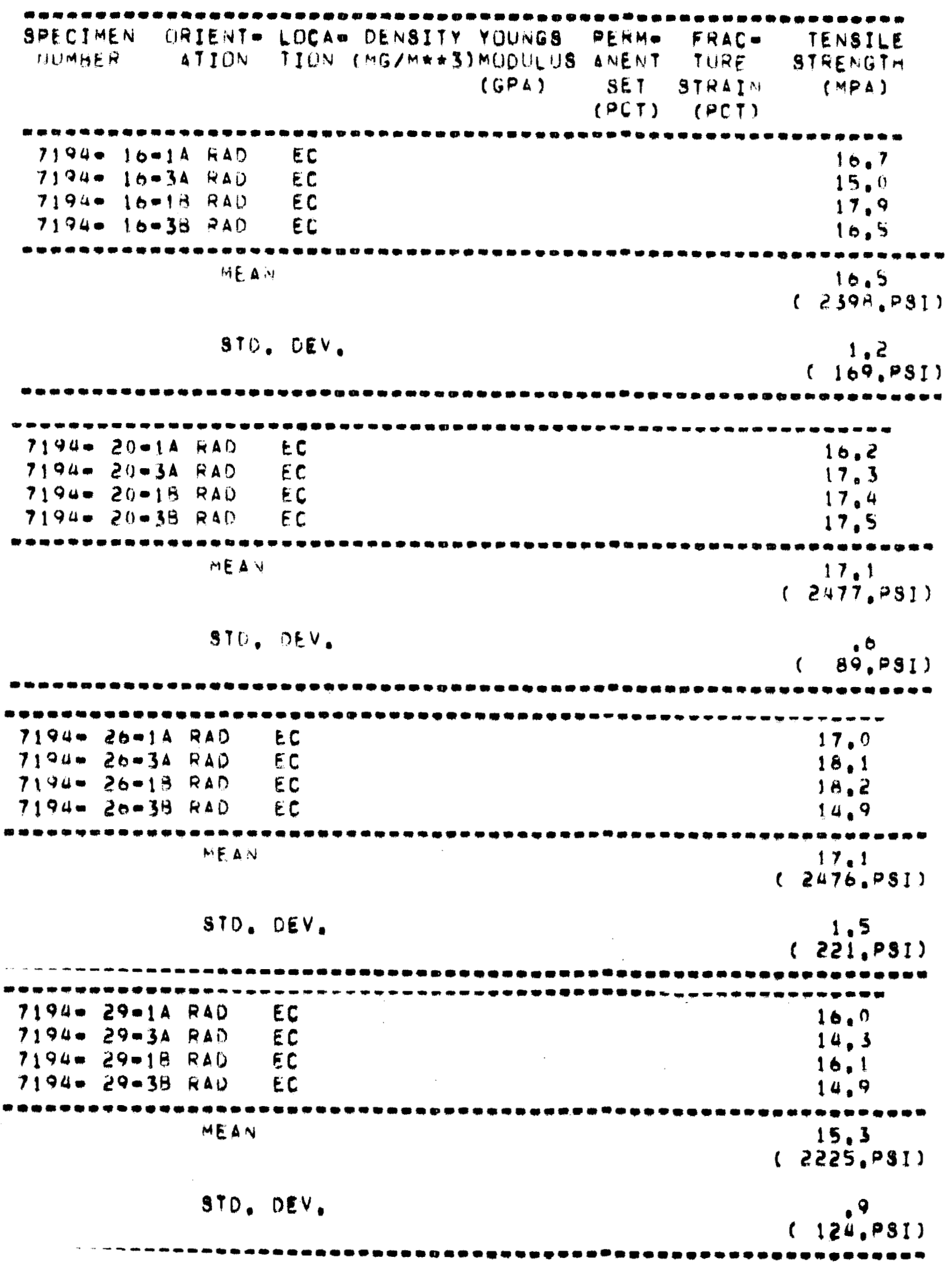




\section{TABLE C-1 (Continued)}

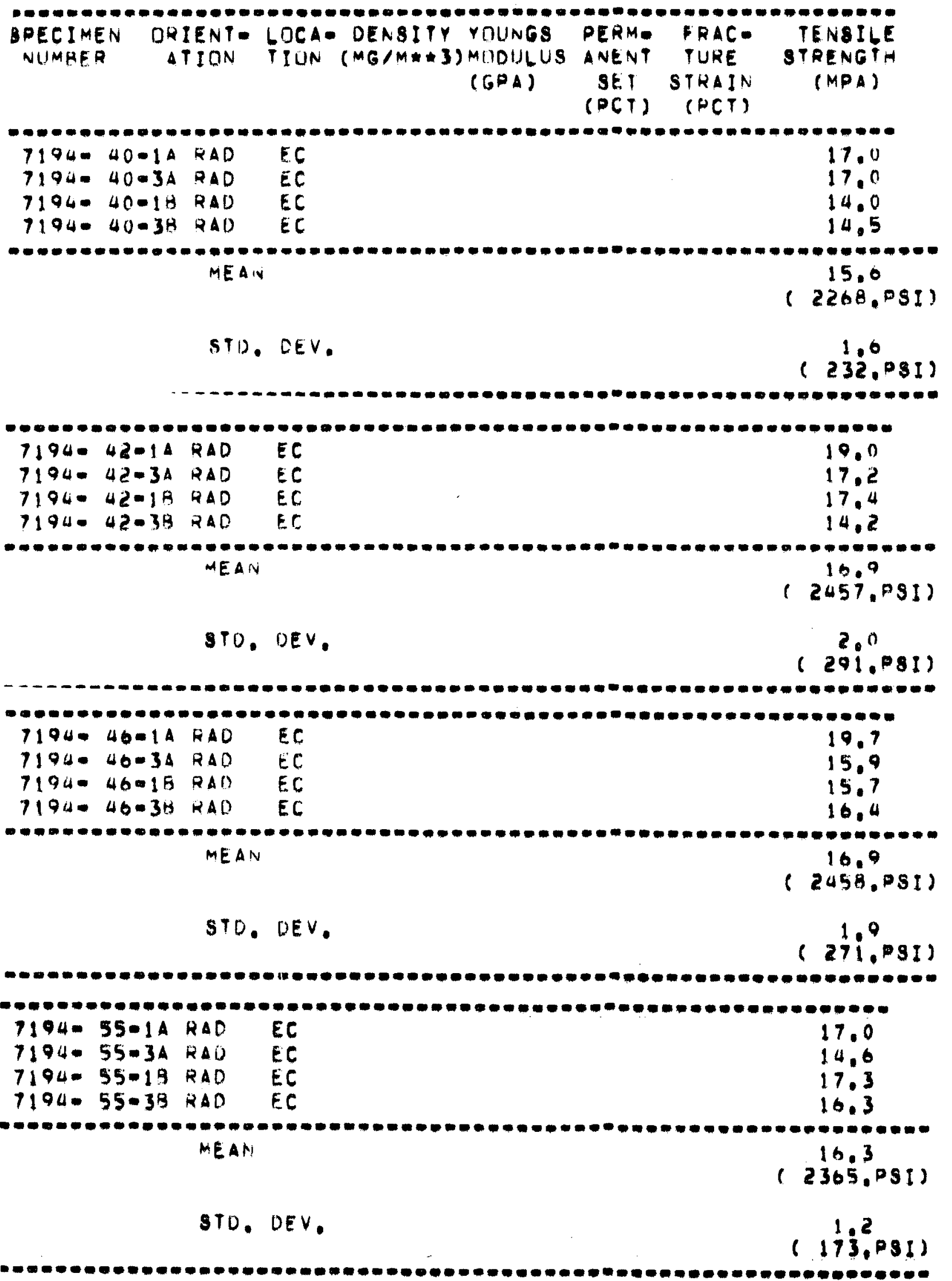




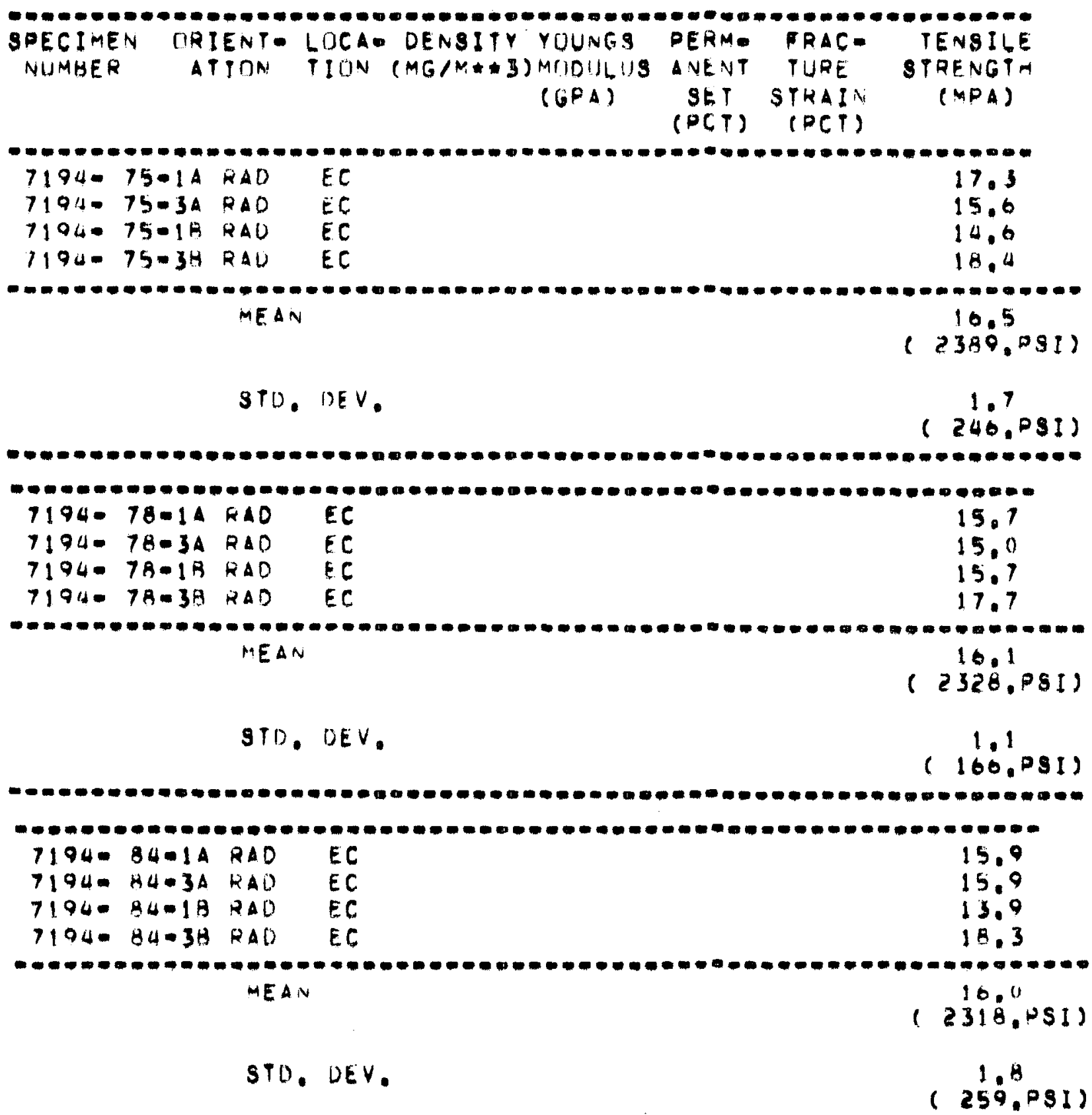

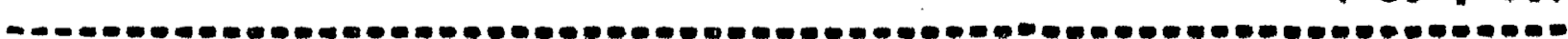

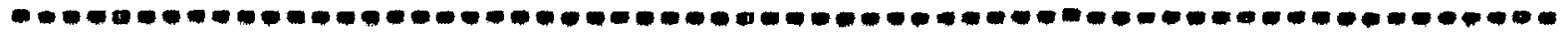
$7194=94-1 A R A D$ EC
$7194=94 \cdot 3 A$ RAD EC
$7194-94 \cdot 19$ RAD EC
$7194=94.3 B$ RAD EC
18.0
17.3
18.4
16.1

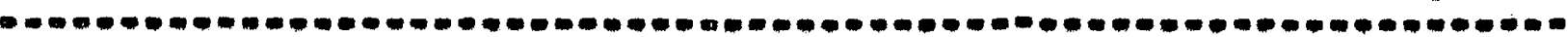
MEA

17.4

(2527.091)

STO. DEV.

1.0

$(152,081)$

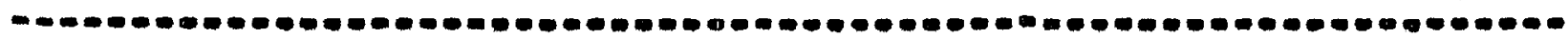




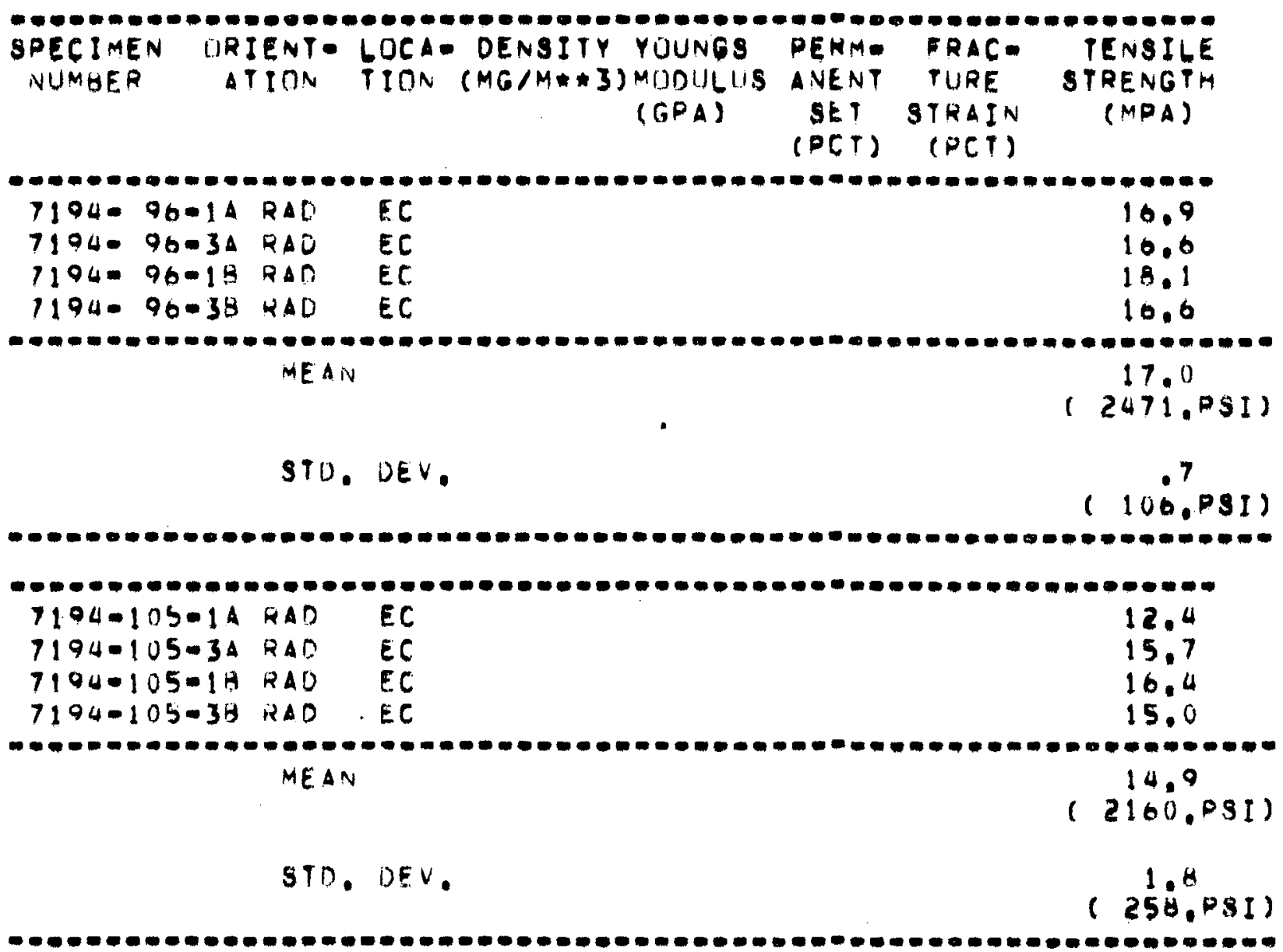


TABLE $\mathrm{C}-2$

RADIAL TENSILE STRENGTH MEASUREMENTS: EXTRUSION LOT 478

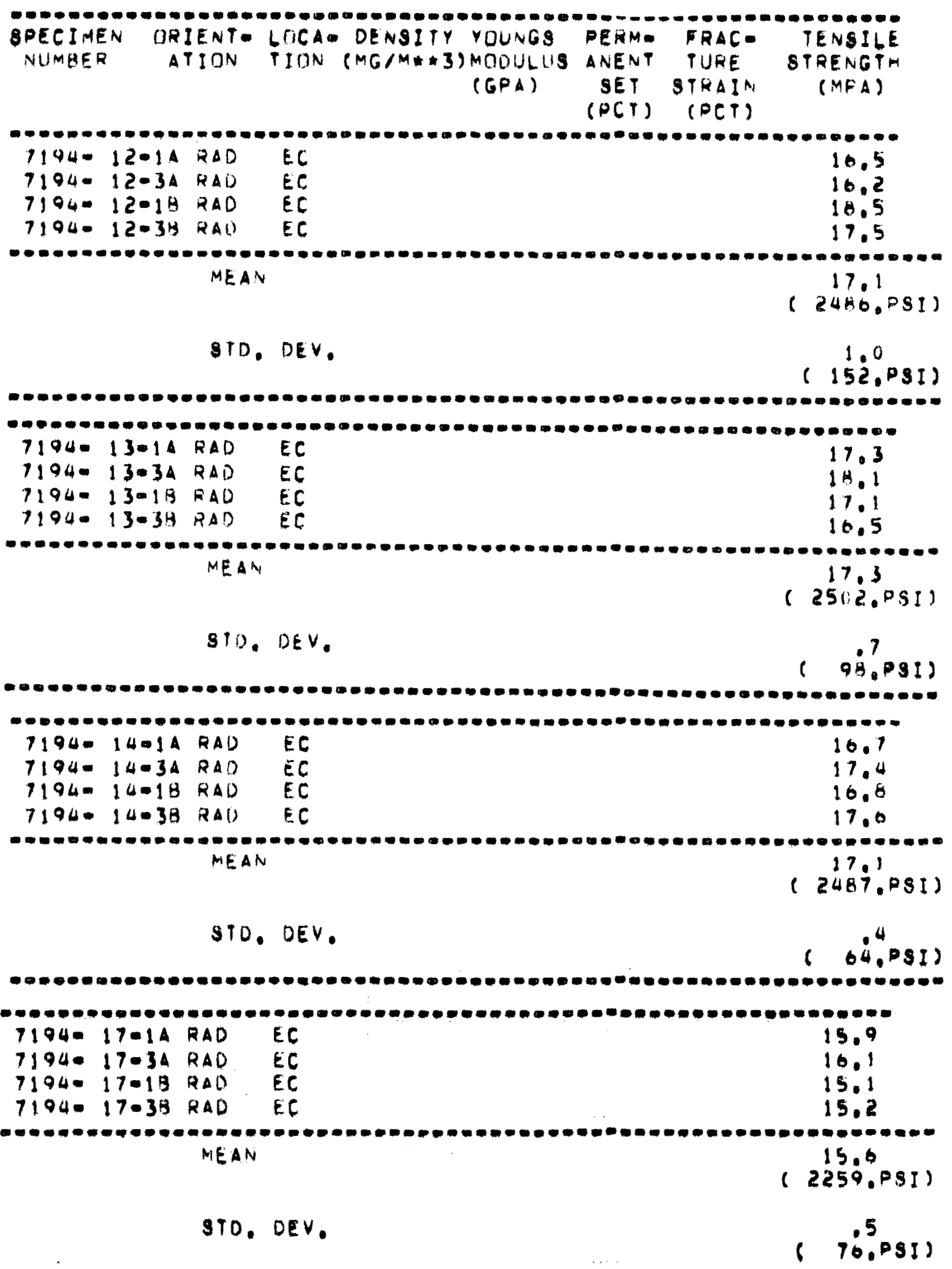

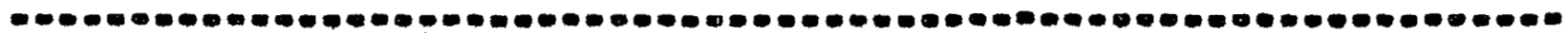




\section{TABLE C-2 (Continued)}

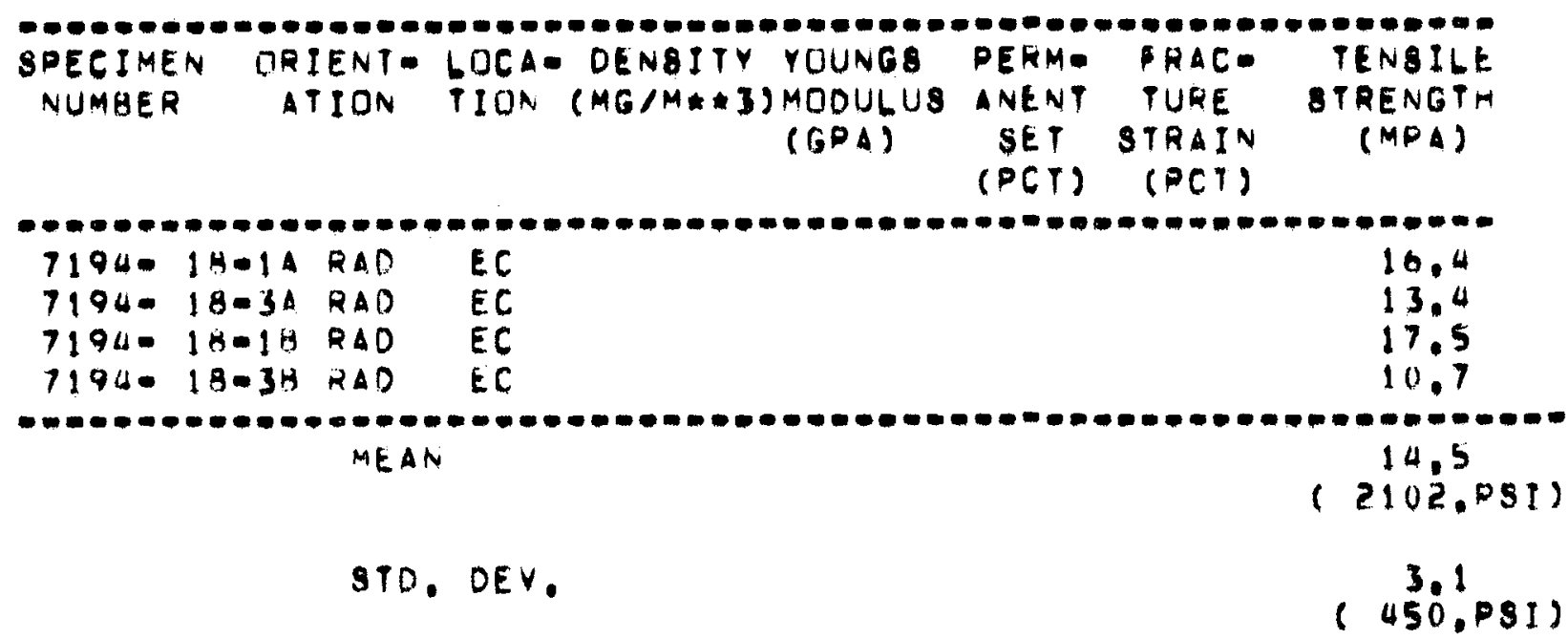

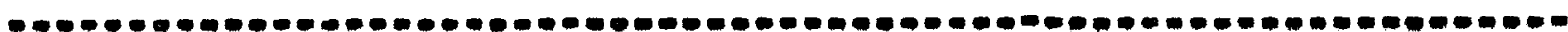

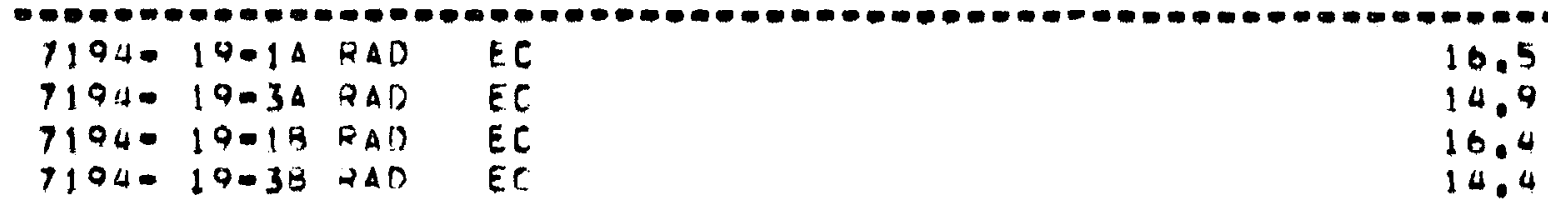

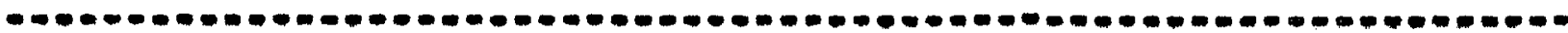
MiEAM

15.5

(2251.PSI)

STD. DEV.

1.1

$(153,091)$

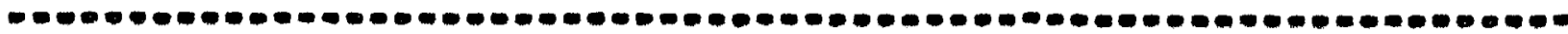

\begin{tabular}{|c|c|c|c|}
\hline $\begin{array}{l}71940 \\
71940 \\
71940 \\
71940\end{array}$ & $\begin{array}{l}24=1 A \\
24=34 \\
24=1 B \\
24-38\end{array}$ & $\begin{array}{l}\text { RAD } \\
R A D \\
R A D \\
R A D\end{array}$ & $\begin{array}{l}E C \\
E C \\
E C \\
E C\end{array}$ \\
\hline
\end{tabular}

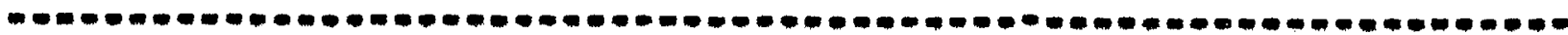
MEAN

14.1

$(2040.91)$

STD. DEV.

2.2

(315.PSI)

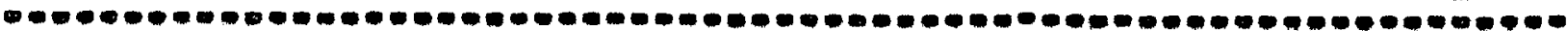

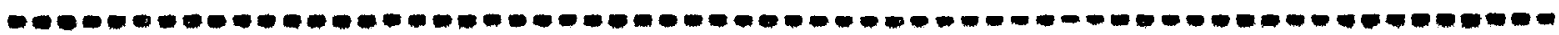

$7194=2 \theta-1 A$ RAD EC

$7194 \cdot 28 \cdot 3 A$ RAD EC

$7194-28 \cdot 1 B$ AAD EC

$7190-28-3 B$ RAD EC

17.0

14,6

14.2

19.5

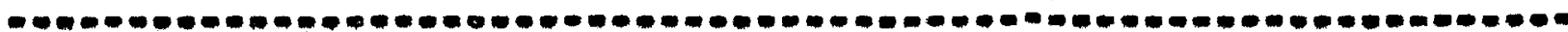

MEN

16,3

(2366.081)

STD. DEV.

2.4

( $354 . P 51)$

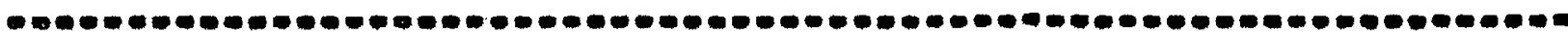




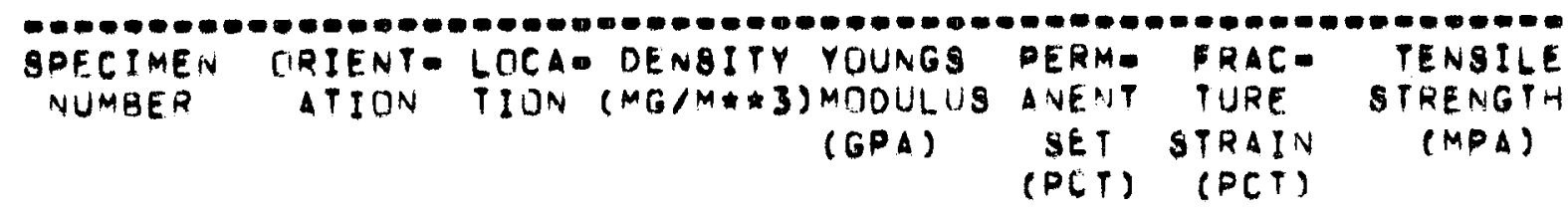

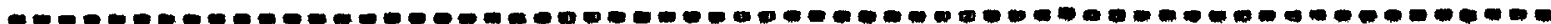

\begin{tabular}{|c|c|c|c|c|}
\hline $\begin{array}{l}7194= \\
7194=\end{array}$ & $\begin{array}{l}30-1 A \\
30=3 A \\
3 U-1 B \\
30-3 B\end{array}$ & $\begin{array}{l}R A D \\
R A D \\
R A D \\
R A D\end{array}$ & $\begin{array}{l}E C \\
E C \\
E C \\
E C\end{array}$ & $\begin{array}{l}10.2 \\
16.0 \\
17.4 \\
13.0\end{array}$ \\
\hline
\end{tabular}

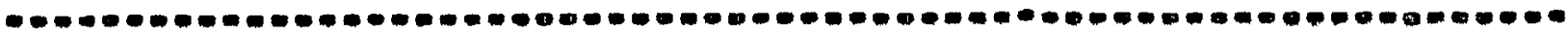

MEAN

17.2

$(2488 . P 31)$

STD. DEV.

1.1

$(162 . P S I)$

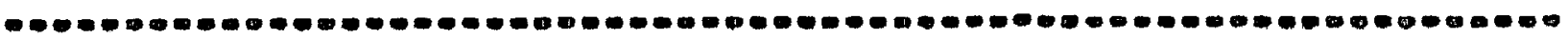

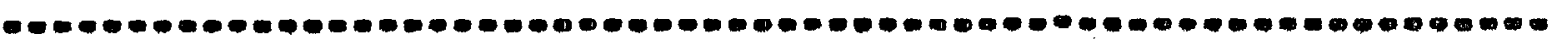

$7194-31-1 A$ RAD EC S

$7194 \% 31-3 A$ RAD EC

$7194031-18$ RAO EC

16.9

$7194-31-3 B$ RAD EC

17.1

15.0

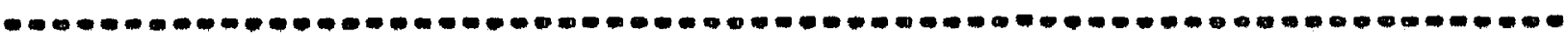
MEA

10.9

( 2440.09 I)

STD. DEV.

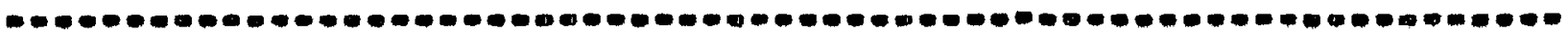

\begin{tabular}{|c|c|c|c|c|}
\hline $\begin{array}{l}7194= \\
7194= \\
7194= \\
7194=\end{array}$ & $\begin{array}{l}33-1 A \\
33=3 A \\
33-1 B \\
33-3 A\end{array}$ & $\begin{array}{l}R A D \\
R A D \\
R A O \\
R A D\end{array}$ & $\begin{array}{l}E C \\
E C \\
E C \\
E C\end{array}$ & $\begin{array}{r}17.3 \\
10.9 \\
8.0 \\
14.0\end{array}$ \\
\hline \multicolumn{5}{|c|}{ 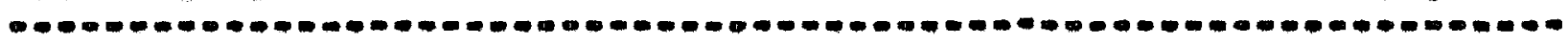 } \\
\hline & & ME & & $\begin{array}{r}14.1 \\
2039\end{array}$ \\
\hline
\end{tabular}

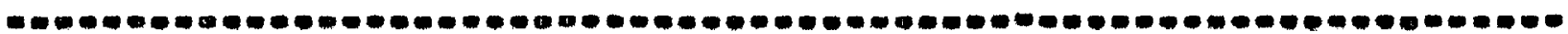

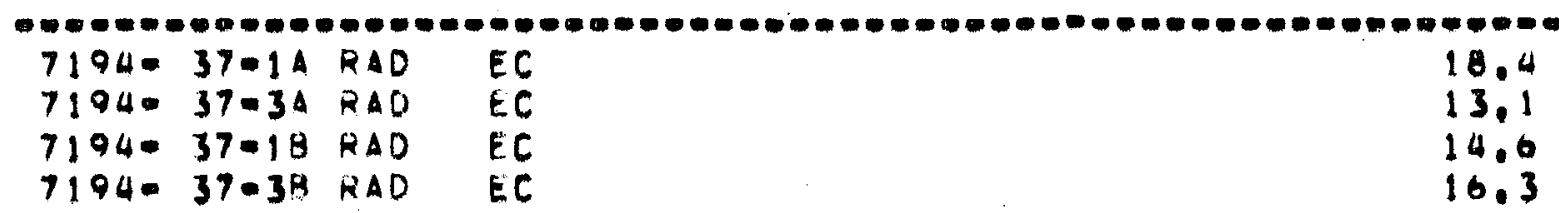

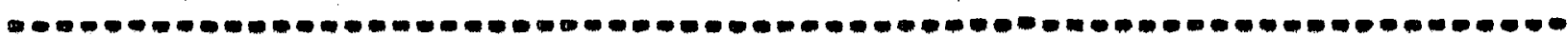
MEAN

15.6

(2263.091)

STO. DEV.

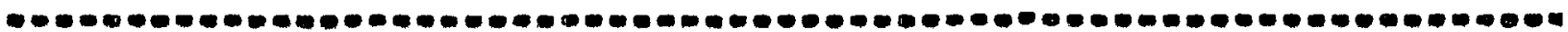


TABLE C-2 (Continued)

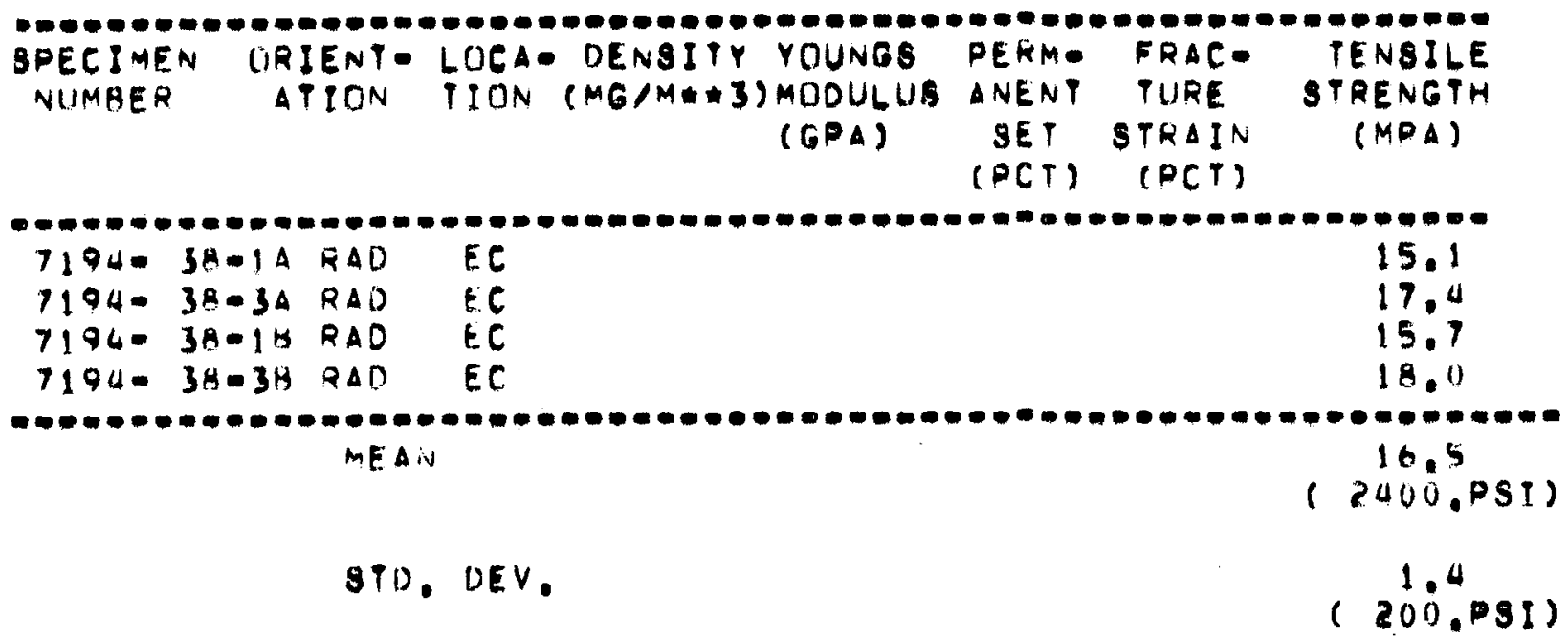

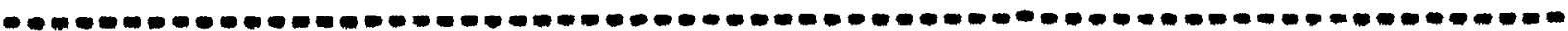

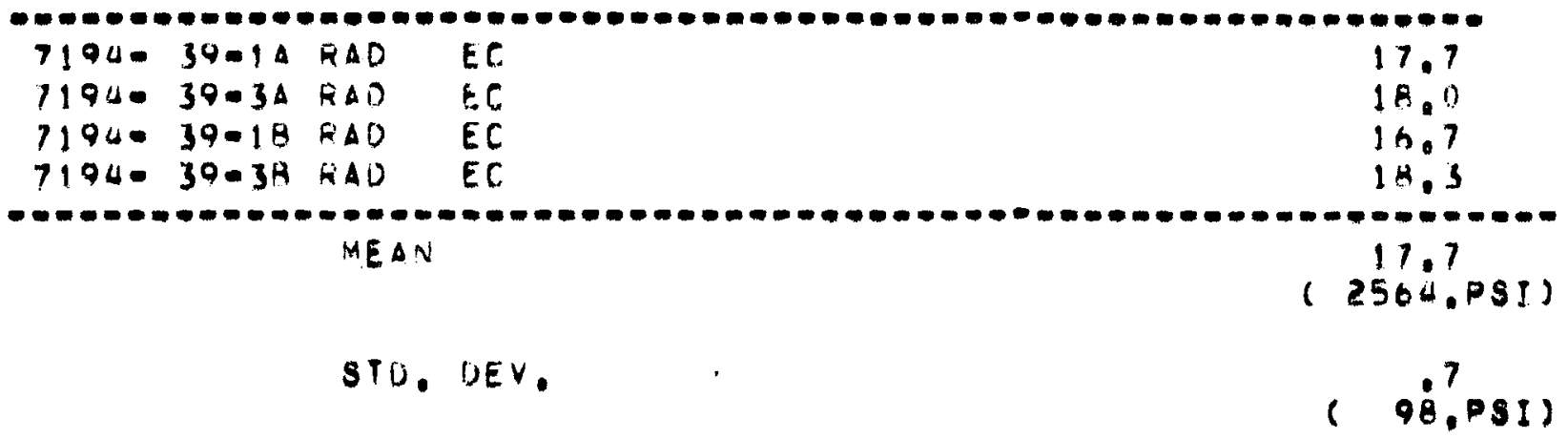

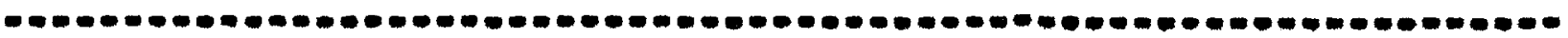

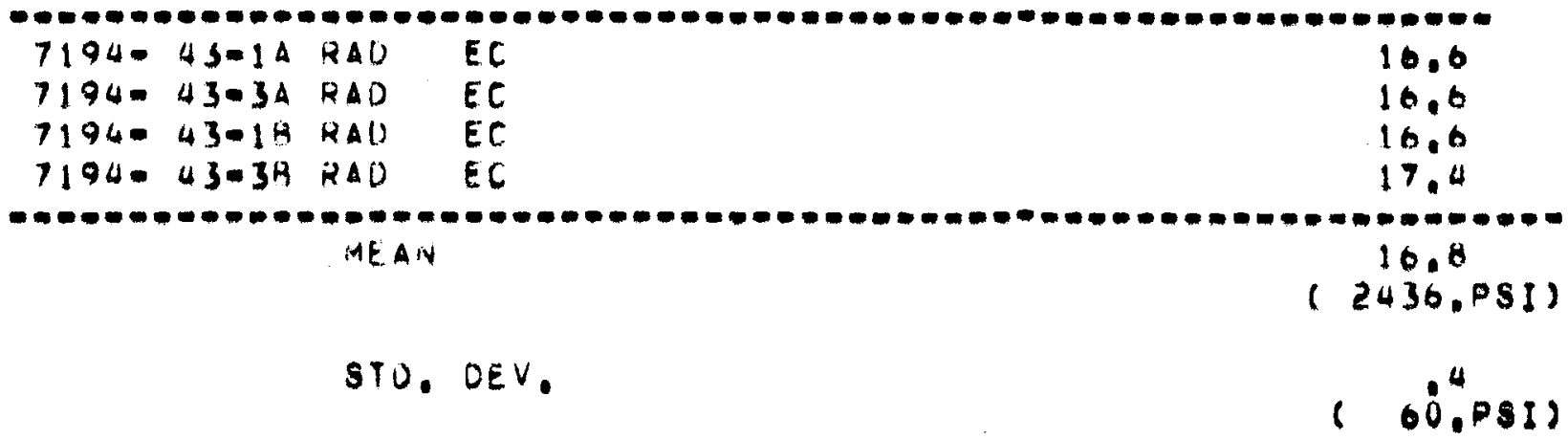

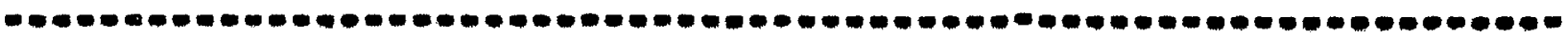

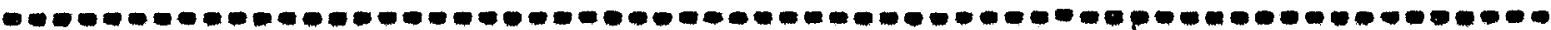

$\begin{array}{llll}7194-47-1 A R A D & E C & 15.9 \\ 7194-47-3 A R A D & E C & 15.1 \\ 7194-47-1 B R A D & E C & 17.4 \\ 7194-47-3 H \text { RAD } & E C & 15.9\end{array}$

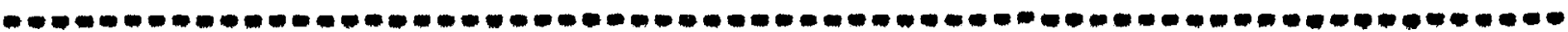
$M E A N$

10.1

( 2330.031$)$

310. DEV.

1.0

$(142, P S 1)$

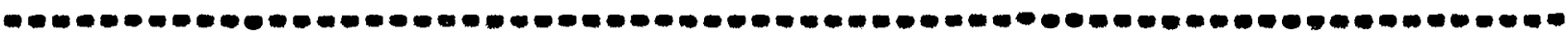


TABLE C-2 (Continued)

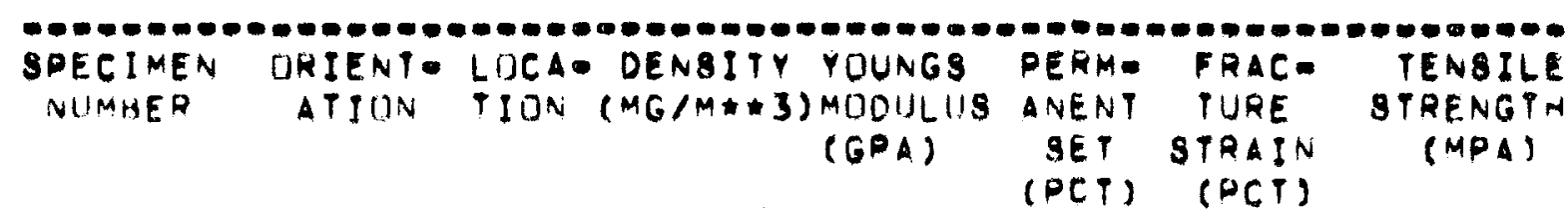

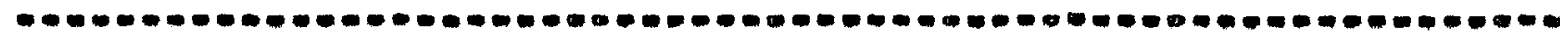
$7194-4 B-1 A$ RAD EC
$7194=48-3 A$ RAC EC
17.5
$7194-48-1 B$ RAD EC
10.3
$7194-48-3 A R A D$
EC
18.7
15.7

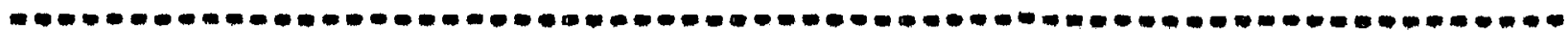
MEAN

17.0

( 2472.091$)$

STO. OEV.

1.3

(189.091)

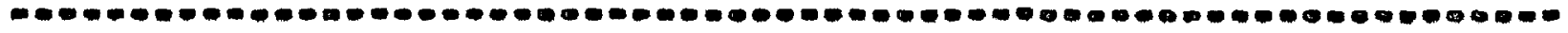

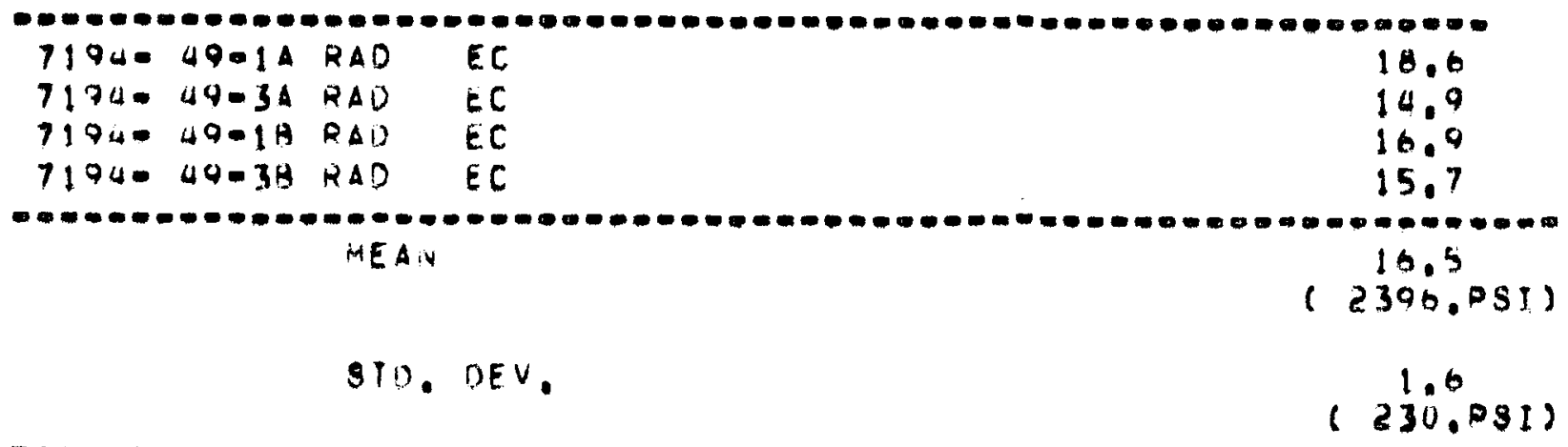

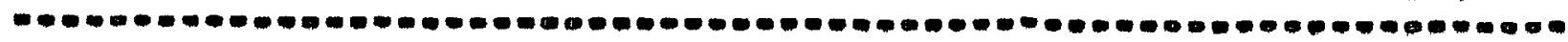

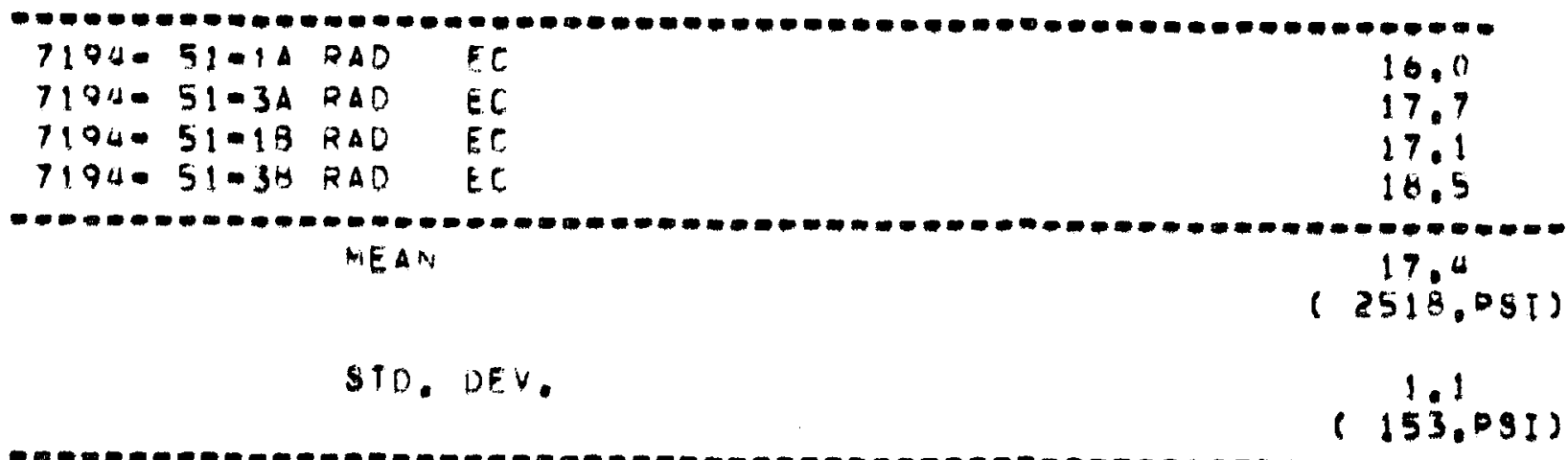

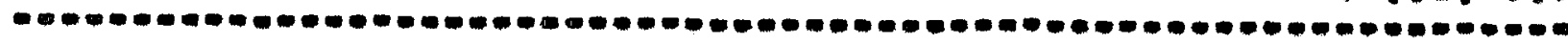

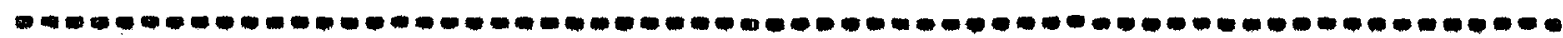

$7194-52-1 A$ RAD EC 17.3

$7194-52-34$ RAD EC ED 15.1

$7194-52-1 B$ RAD EC EC

$7194=52-3 B$ KAD EC 15.2

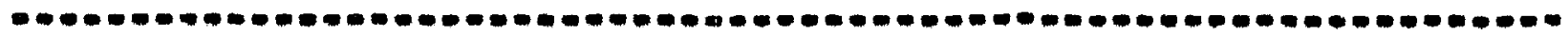
MEN

16.2

$(2350.91)$

STO. OEV.

1.3

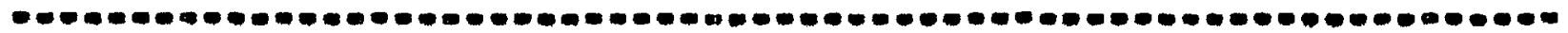


TABLE C-2 (Continued)

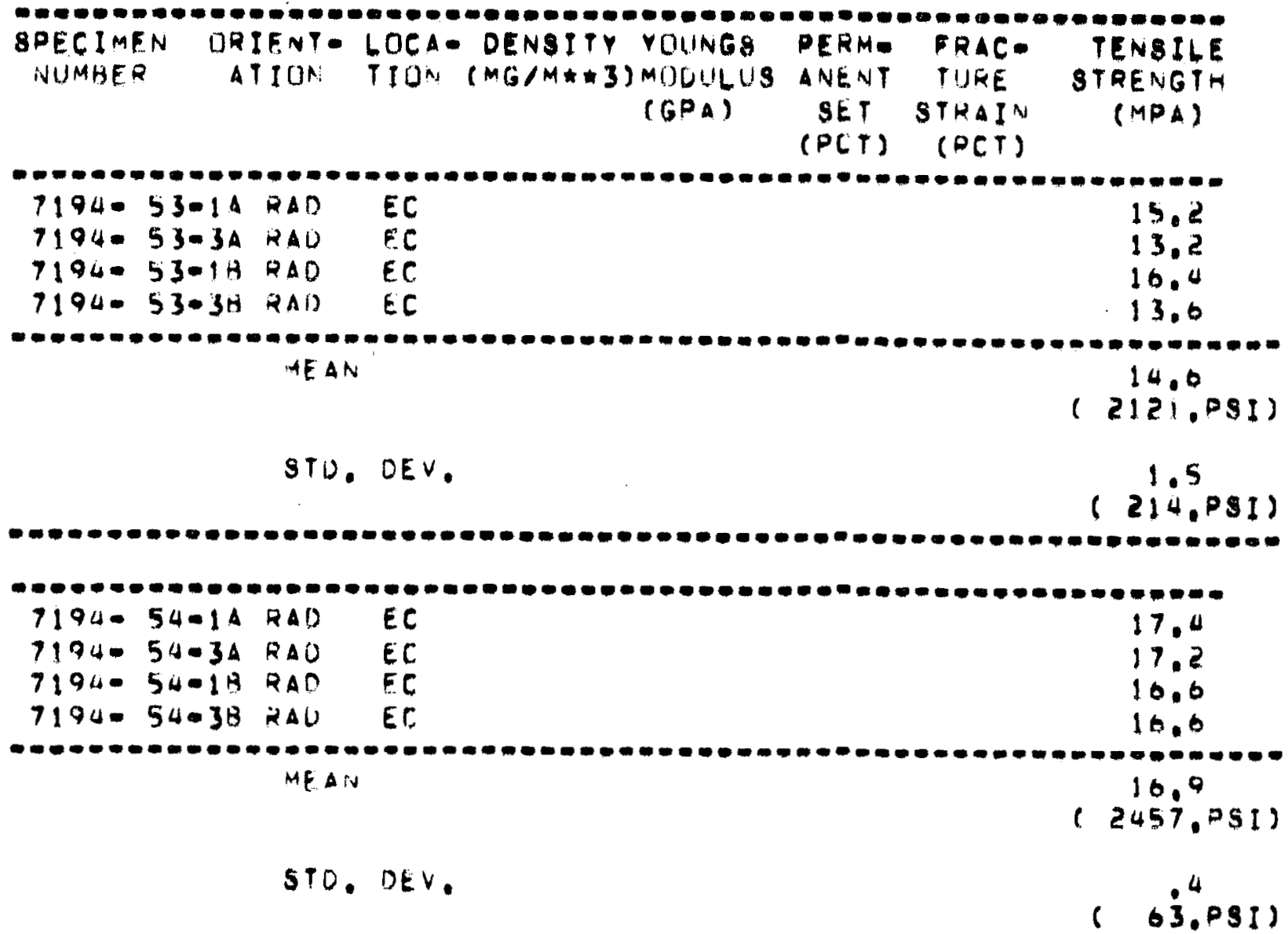

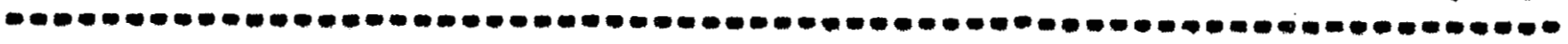

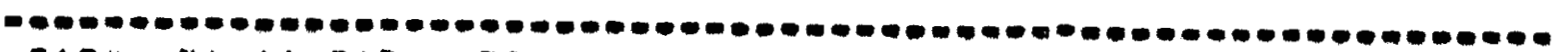

$7194056-1 A$ RAD EC

$7194-56-34$ RAD EC

$7194-56-1 B$ RAD EC

$7194-50-36$ RAD EC

15.9

15.8

15.5

16.3

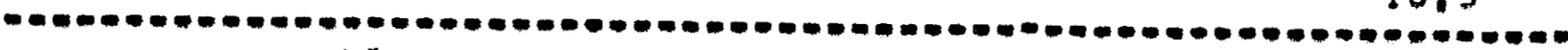
MEAN

STU. DEV.

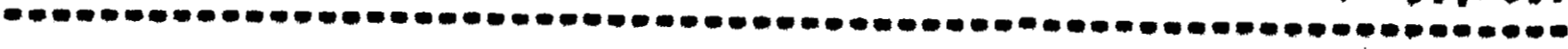

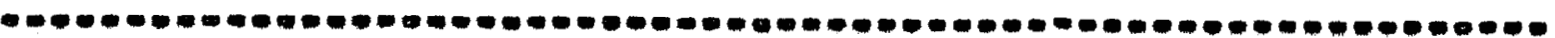

$71940-57-1 A$ RAD EC

$7194-57-3 A$ RAD EC

$7194-57-19$ RAD EC

15.9

18.1

$7194057-3 A$ RAD EC

19.2

$M E A N$

16,7

(2425.091)

STO. DEV.

2.5

(302.PSI)

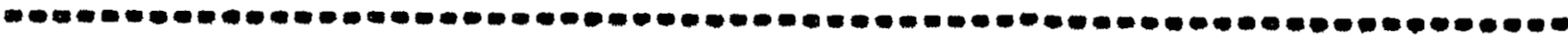




\section{TABLE C-2 (Continued)}

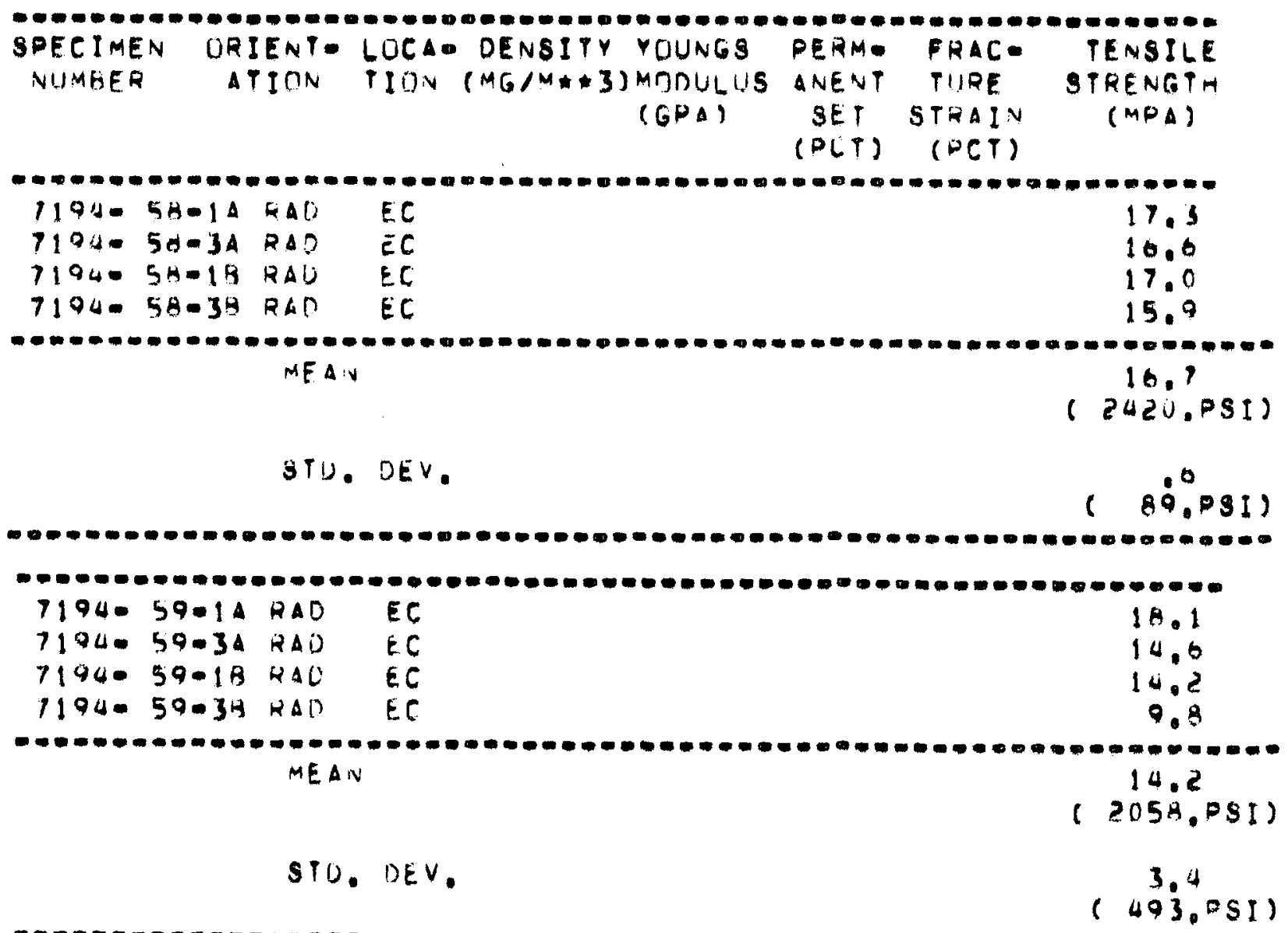

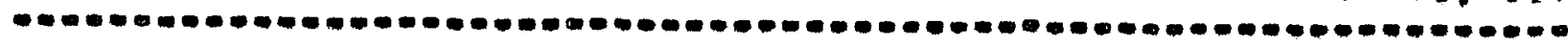

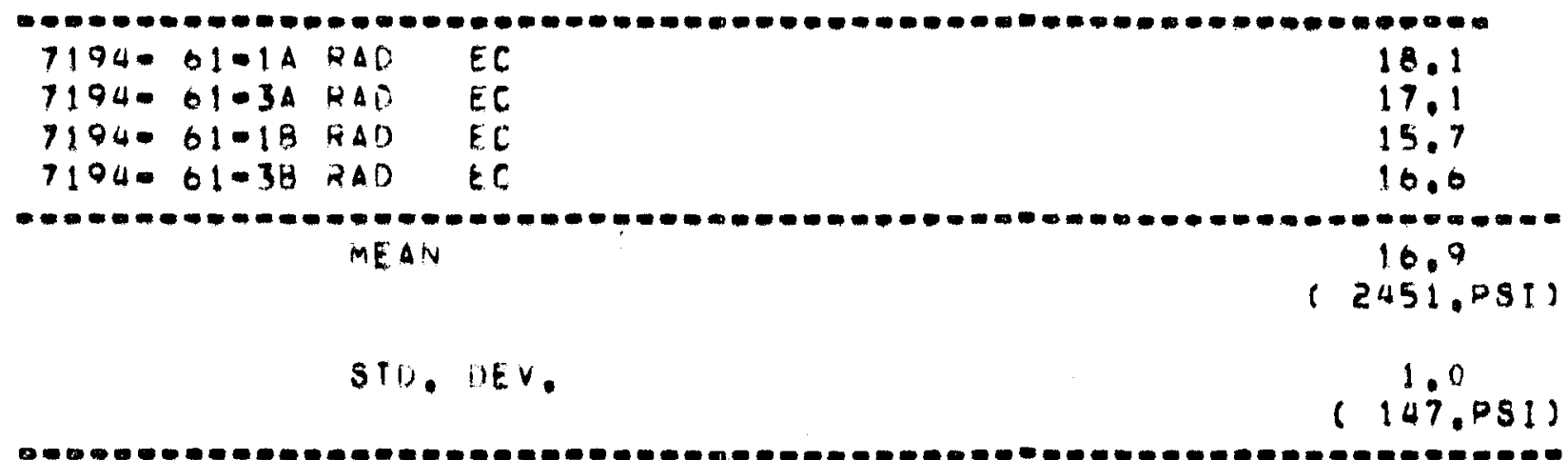

\begin{tabular}{|c|c|c|c|}
\hline $\begin{array}{l}7194= \\
7194= \\
7194= \\
7190=\end{array}$ & $\begin{array}{l}63-1 A \\
63-3 A \\
63-1 B \\
63-3 B\end{array}$ & $\begin{array}{l}R A D \\
H A D \\
R A D \\
R A D\end{array}$ & $\begin{array}{l}E C \\
E C \\
E C \\
E C\end{array}$ \\
\hline
\end{tabular}

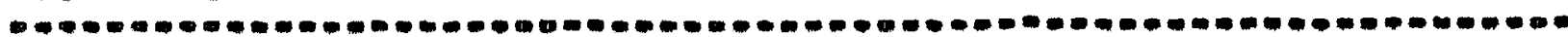
$M E A N$

16.3

(2363.PSI)

STD. DEV.

1.0

$(104.08 I)$

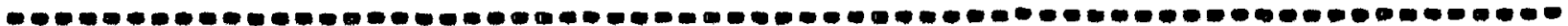




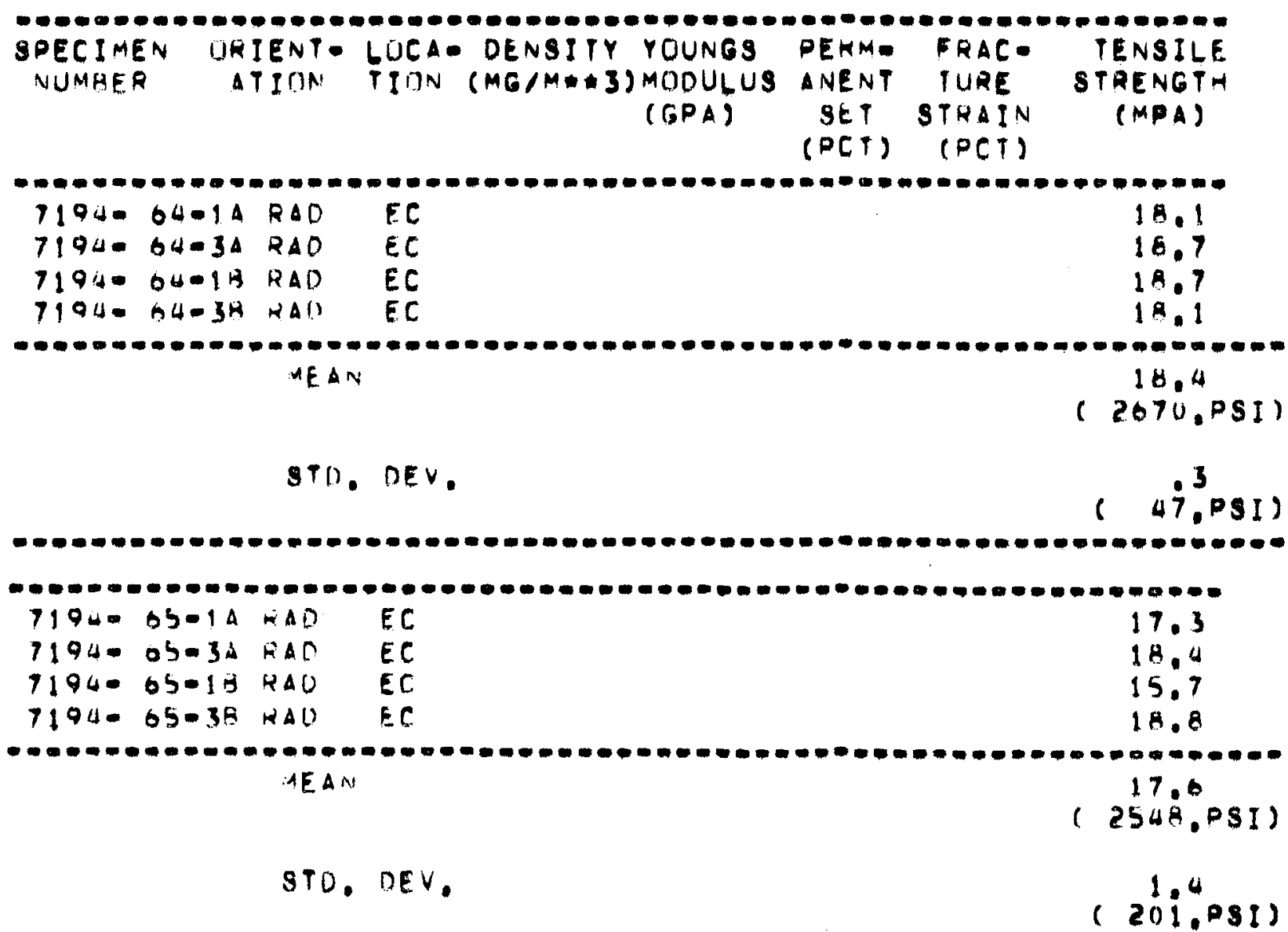

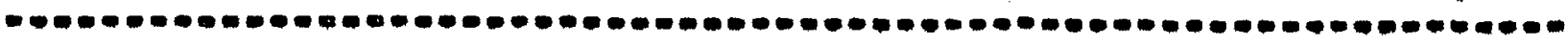

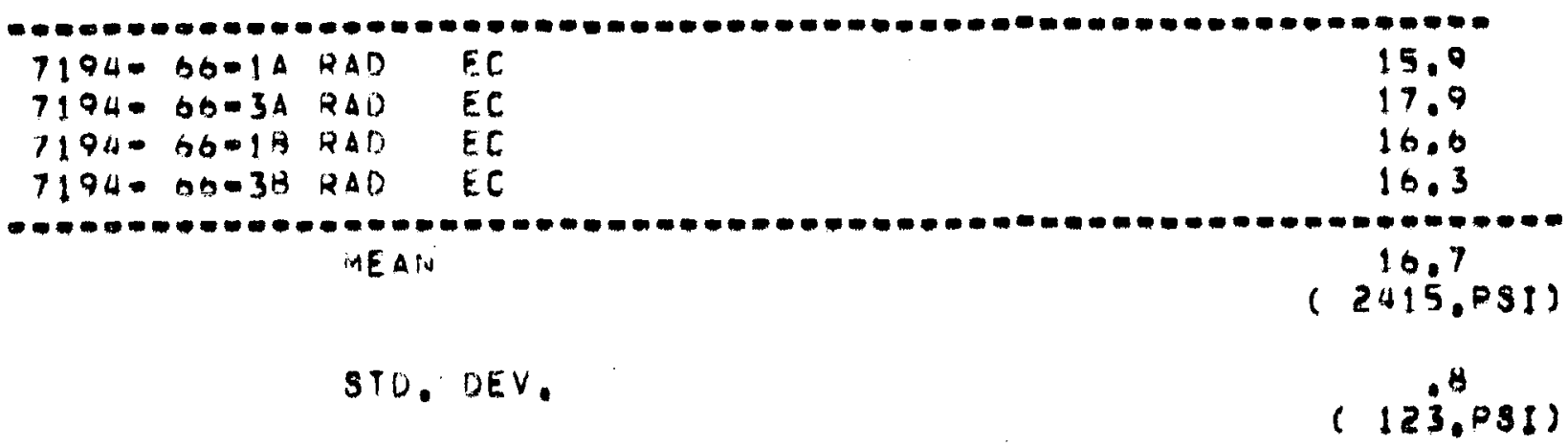

ด.

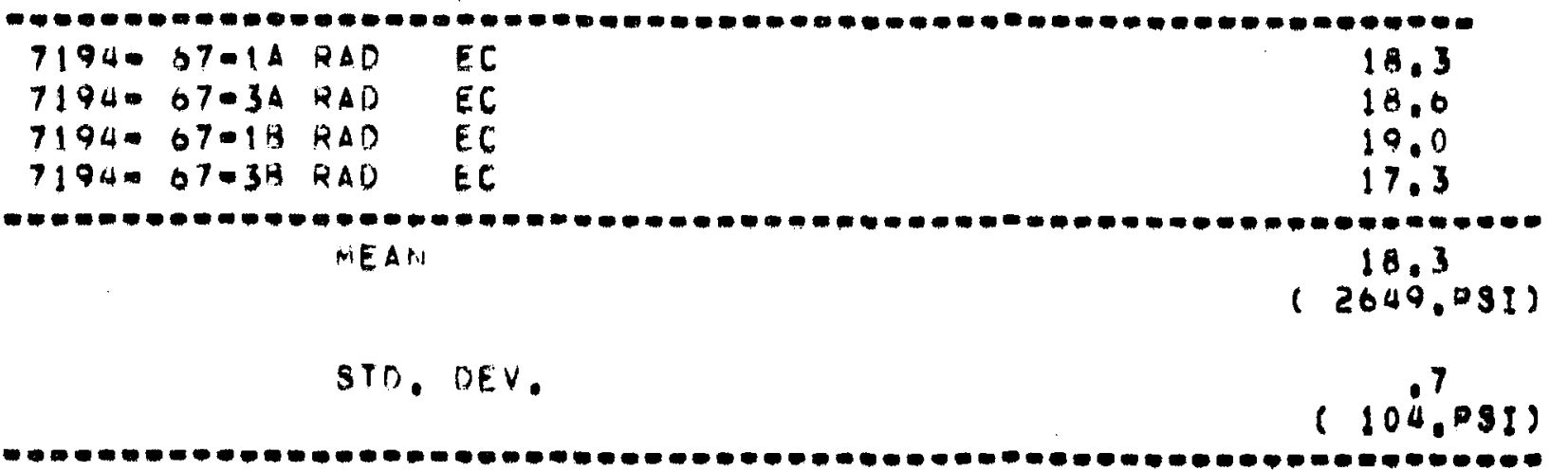


TABLE C-2 (Continued)

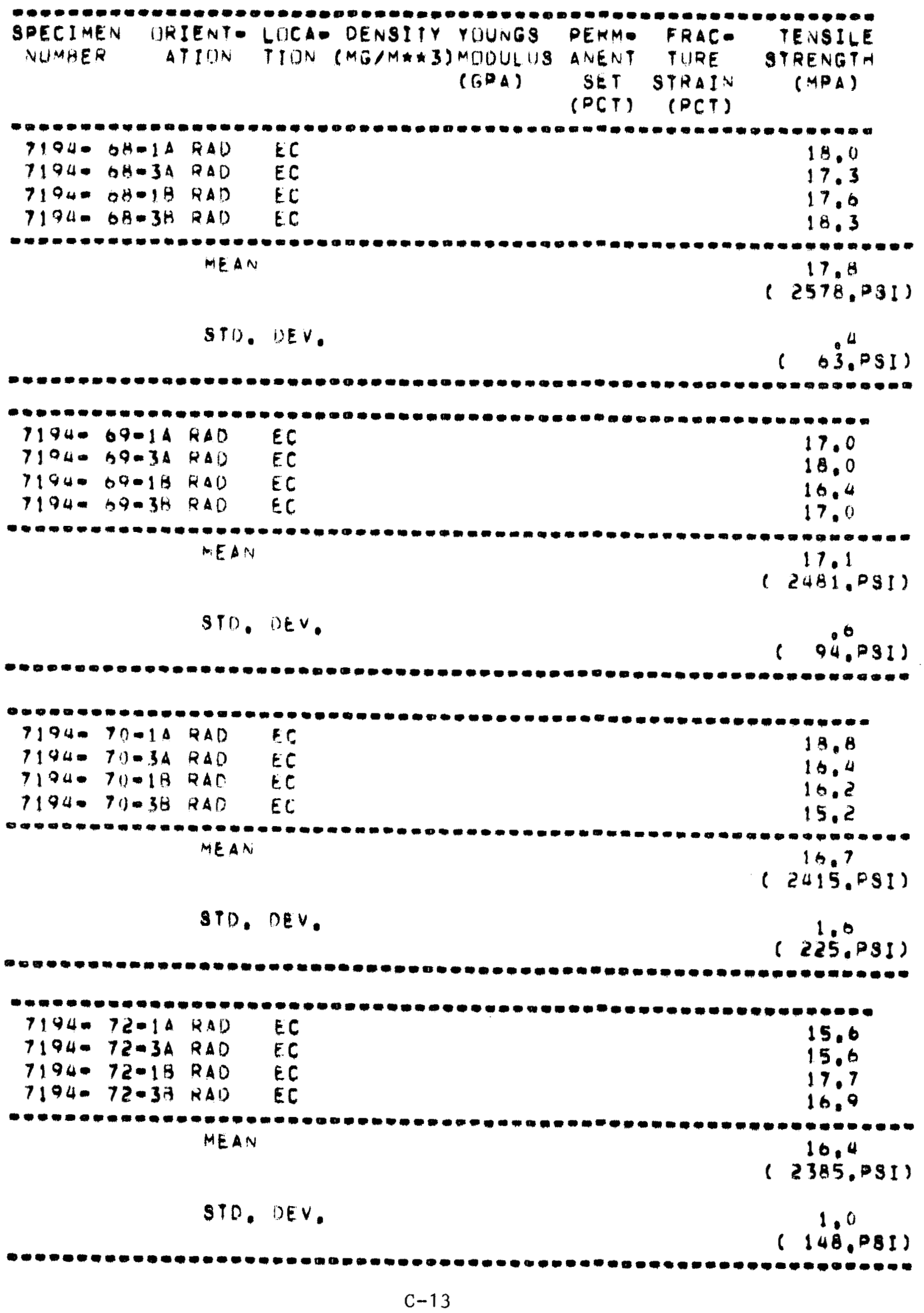


TABLE C-2 (Continued)

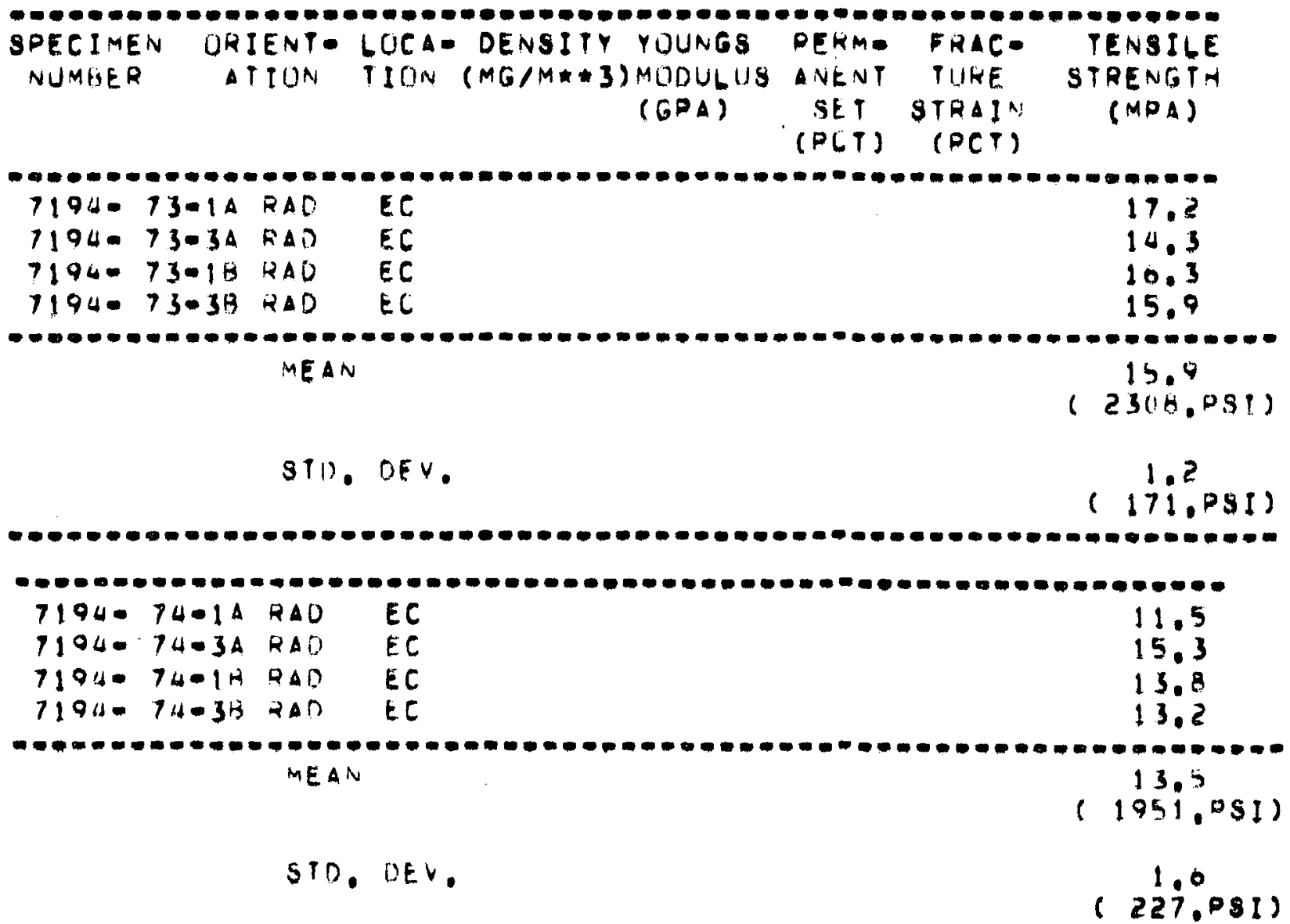

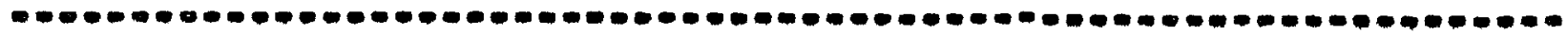

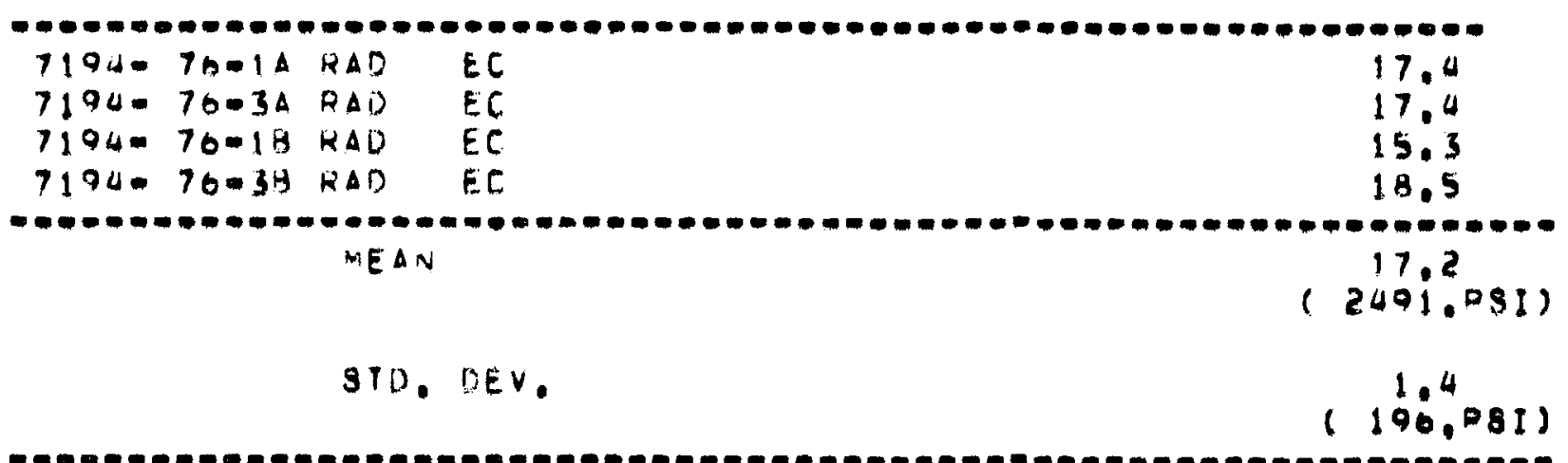

$\begin{array}{lll}7194=79-1 A \text { RAD } & \text { EC } & 15.6 \\ 7194-79-3 A \text { RAD } & \text { EC } & 15.6 \\ 7144-79-1 B \text { RAD } E C & 15.7 \\ 7194-79-3 B \text { RAD } & \text { EC } & 13.8\end{array}$

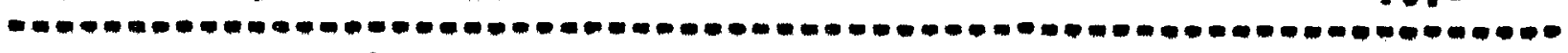
MEA

15.2

$(2201.091)$

$$
\text { STD. DEV. }
$$

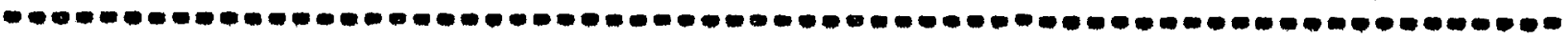

$$
\text { C }-14
$$


TABLE C-2 (Continued)

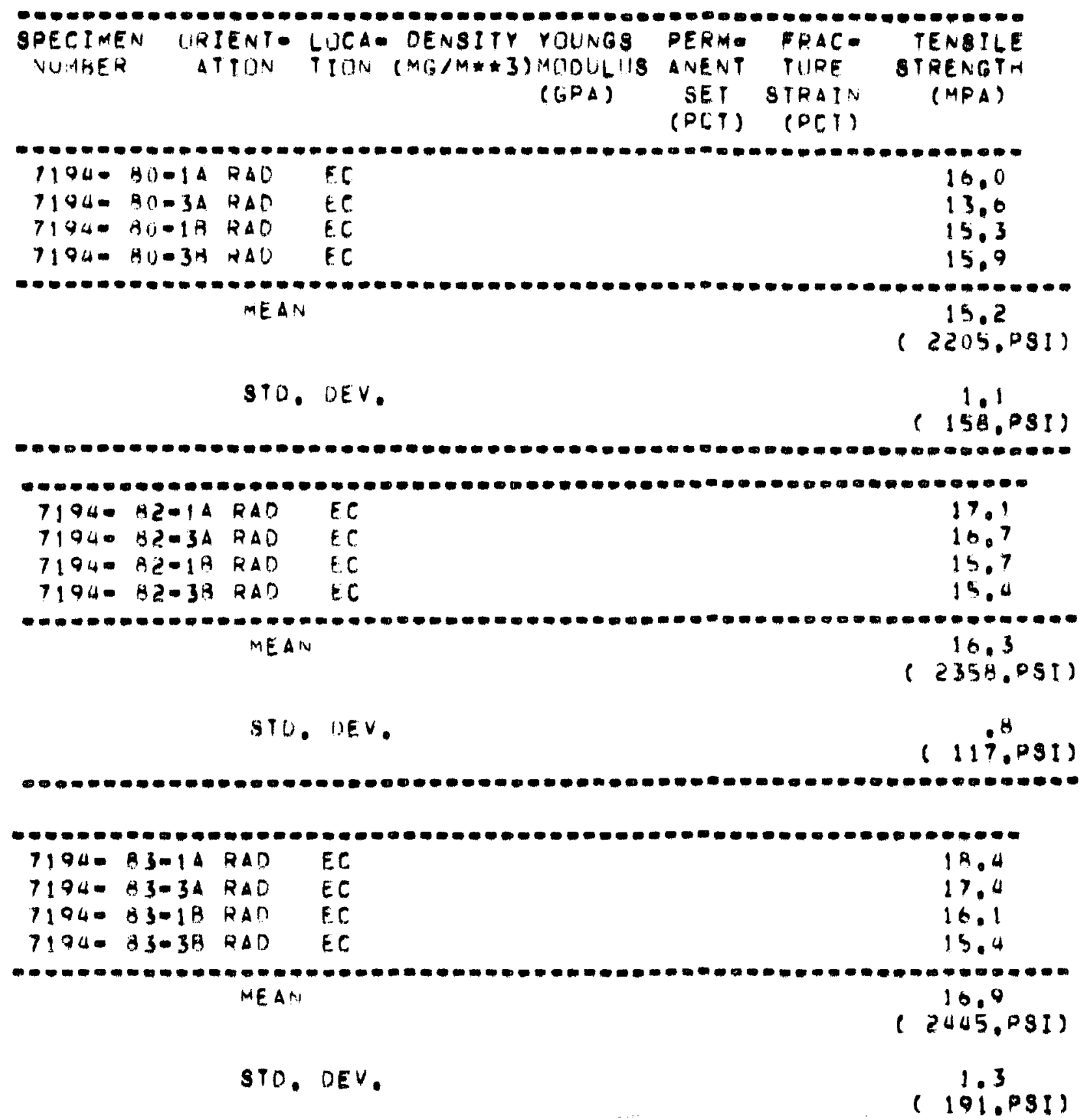

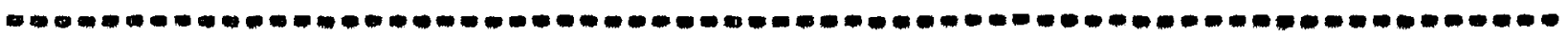

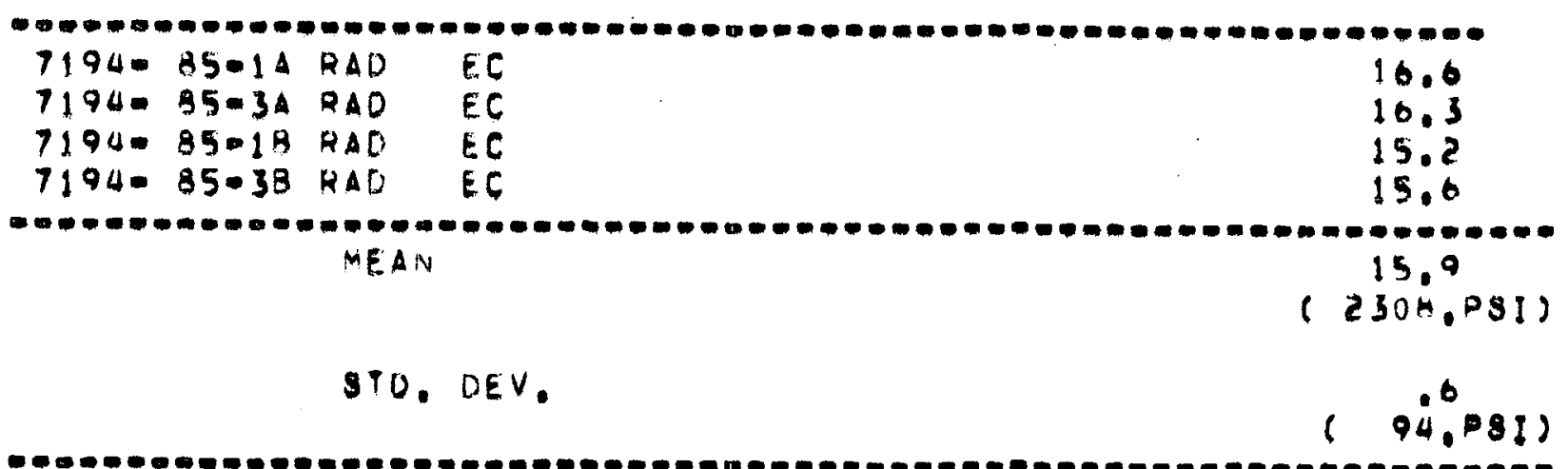




\section{TABLE C-2 (Continued)}

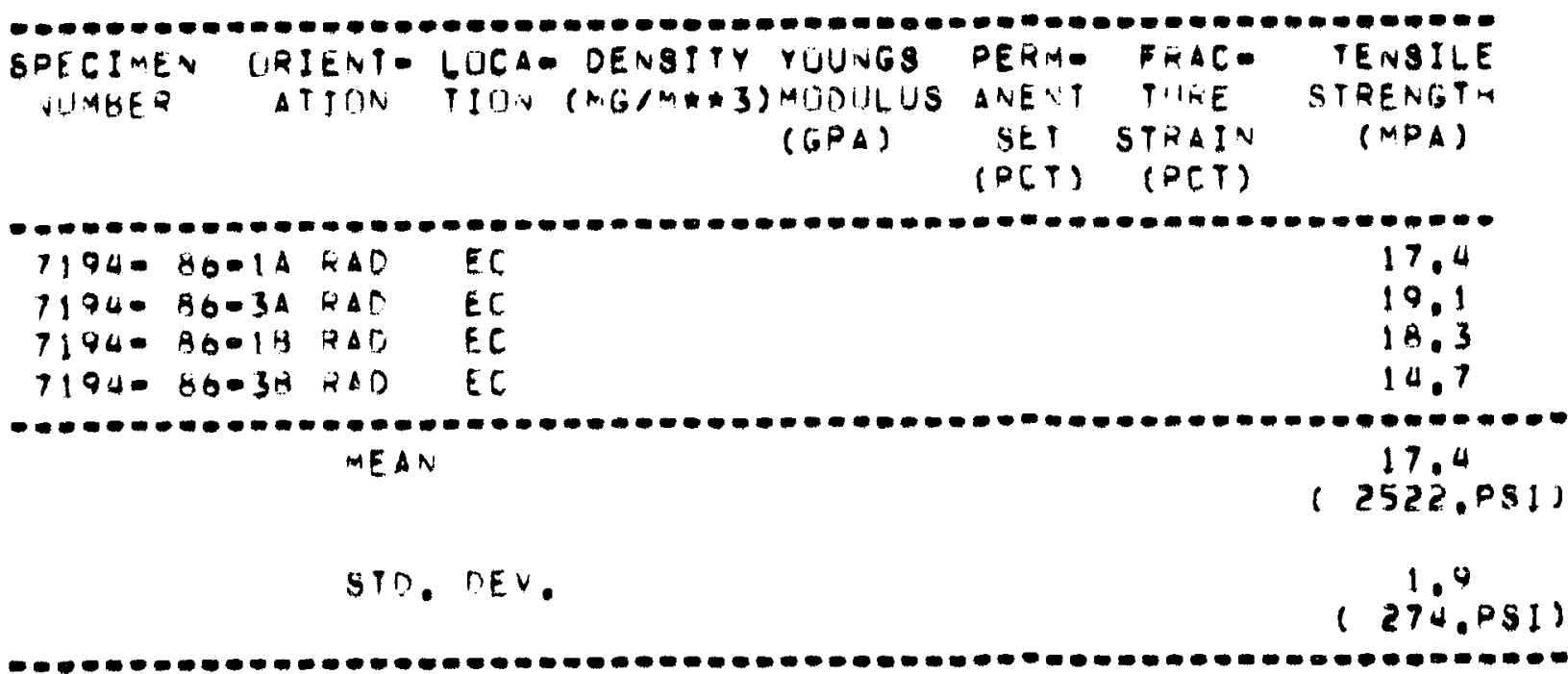

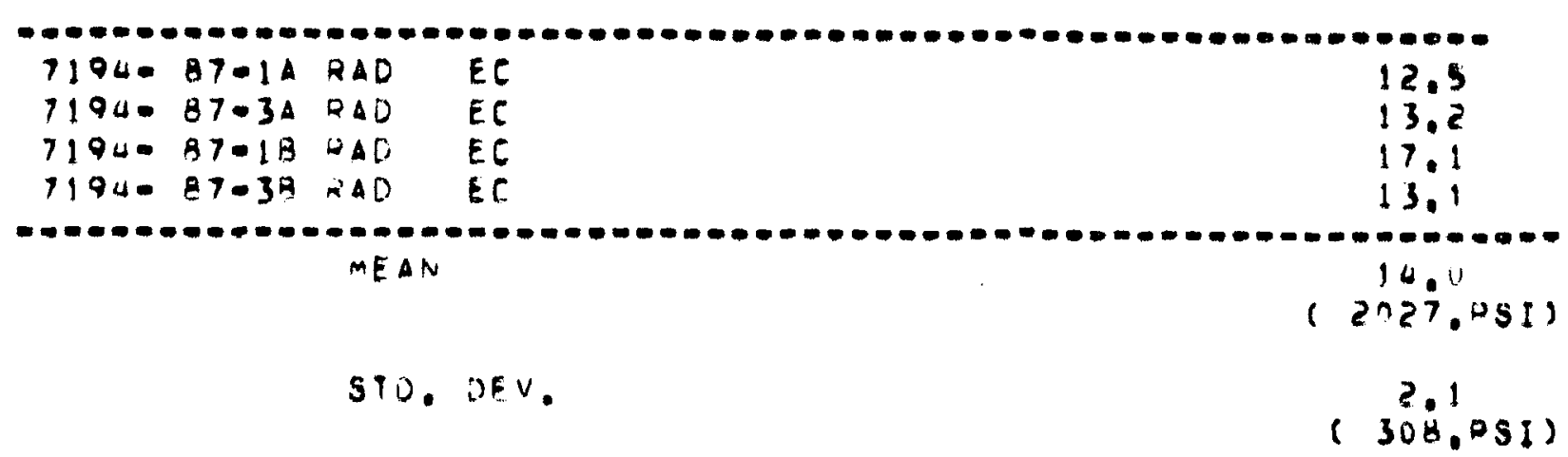

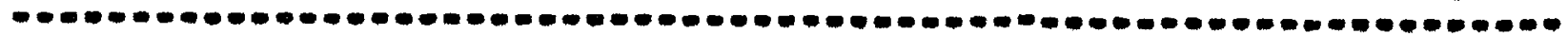

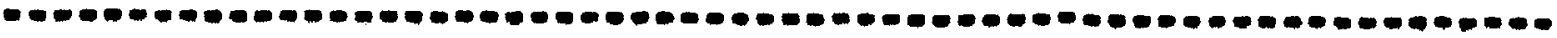

7194. 3AOIA RAD EP

$7194058-3 A$ RAO EC

$7194-8 B=1 A$ RAD EC

$71940.8 B-3 A$ RAD EC

16.4

18,7

16.6

17.7

$-0.000 .0000-0.000000$

17.4

$M E A N$

(2517.PSI)

STD. DEV.

1.1

$(154.091)$

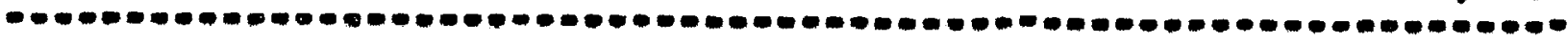

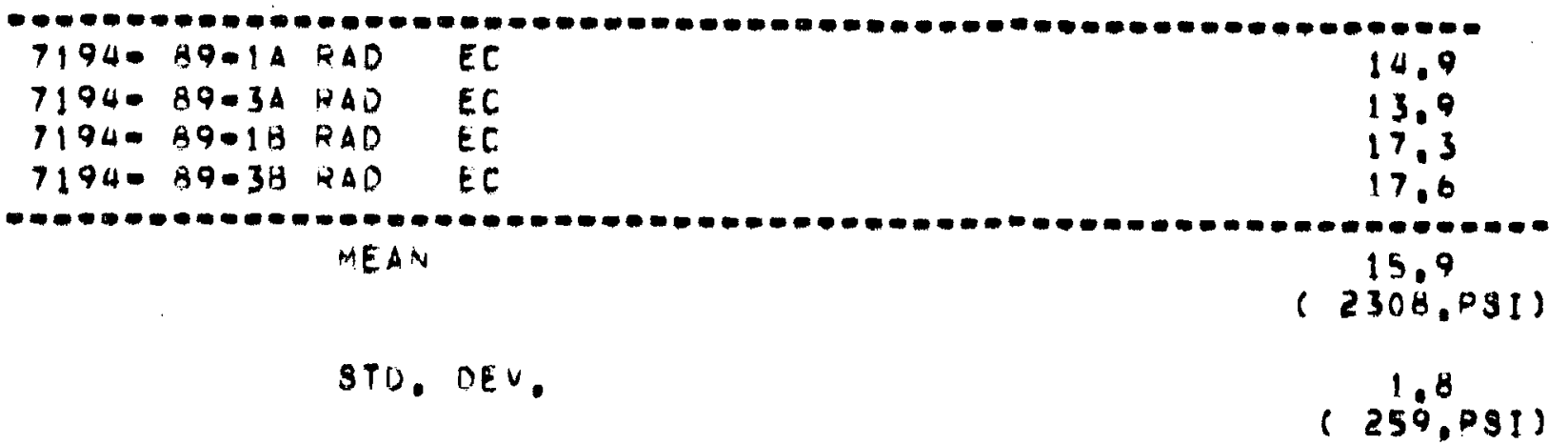

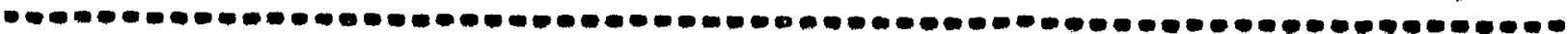




\section{TABLE C-2 (Continued)}

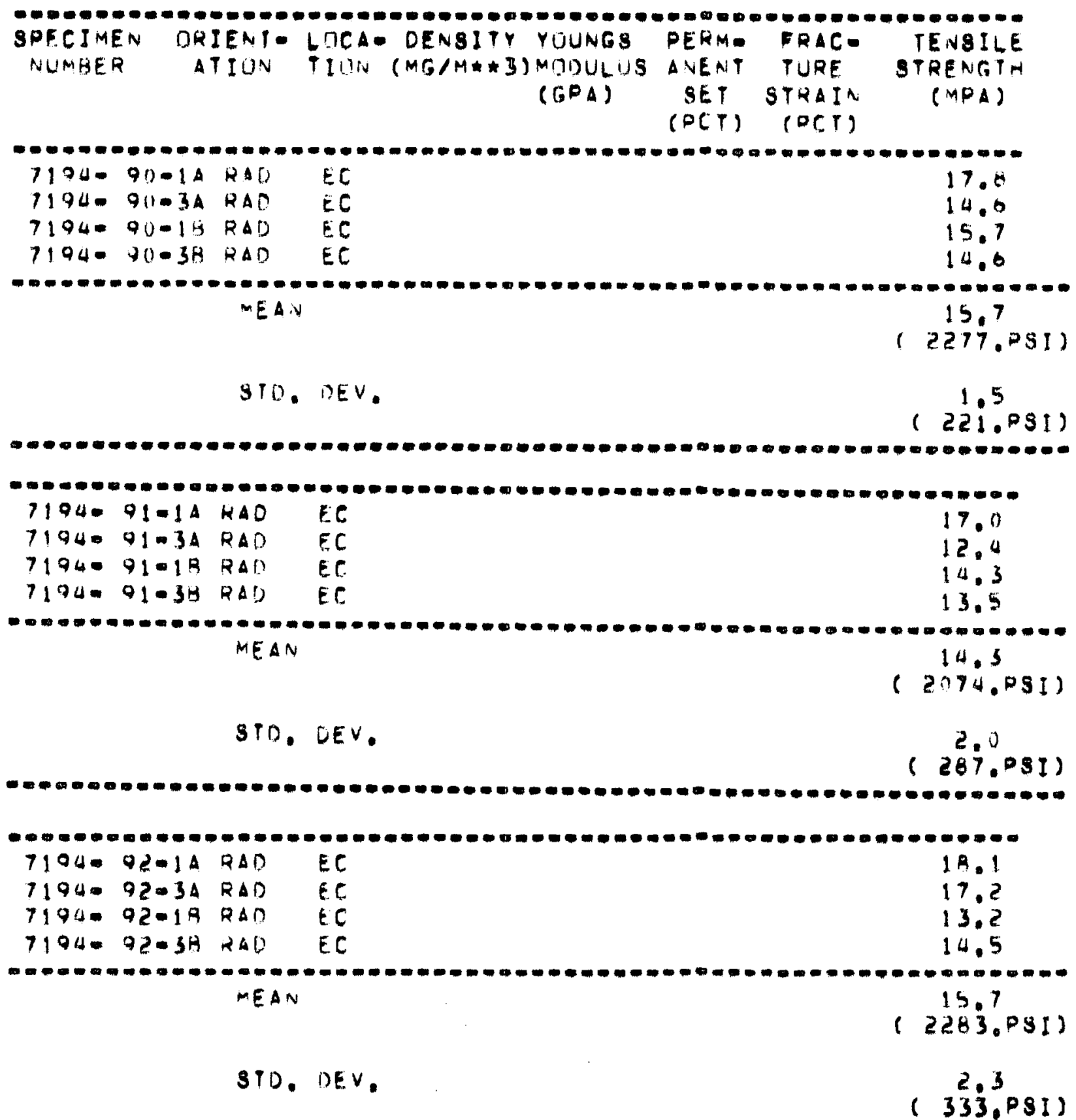

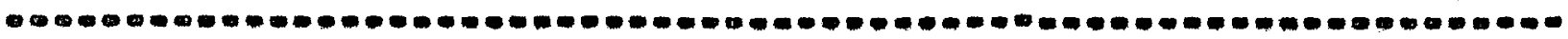

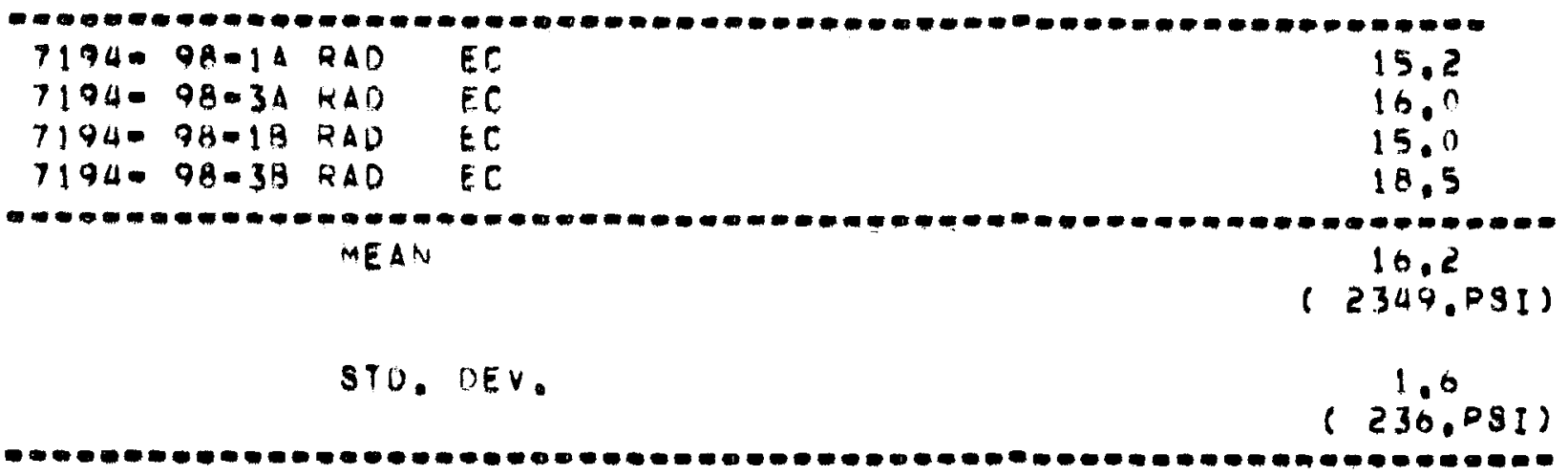


TABLE C-2 (Continued)

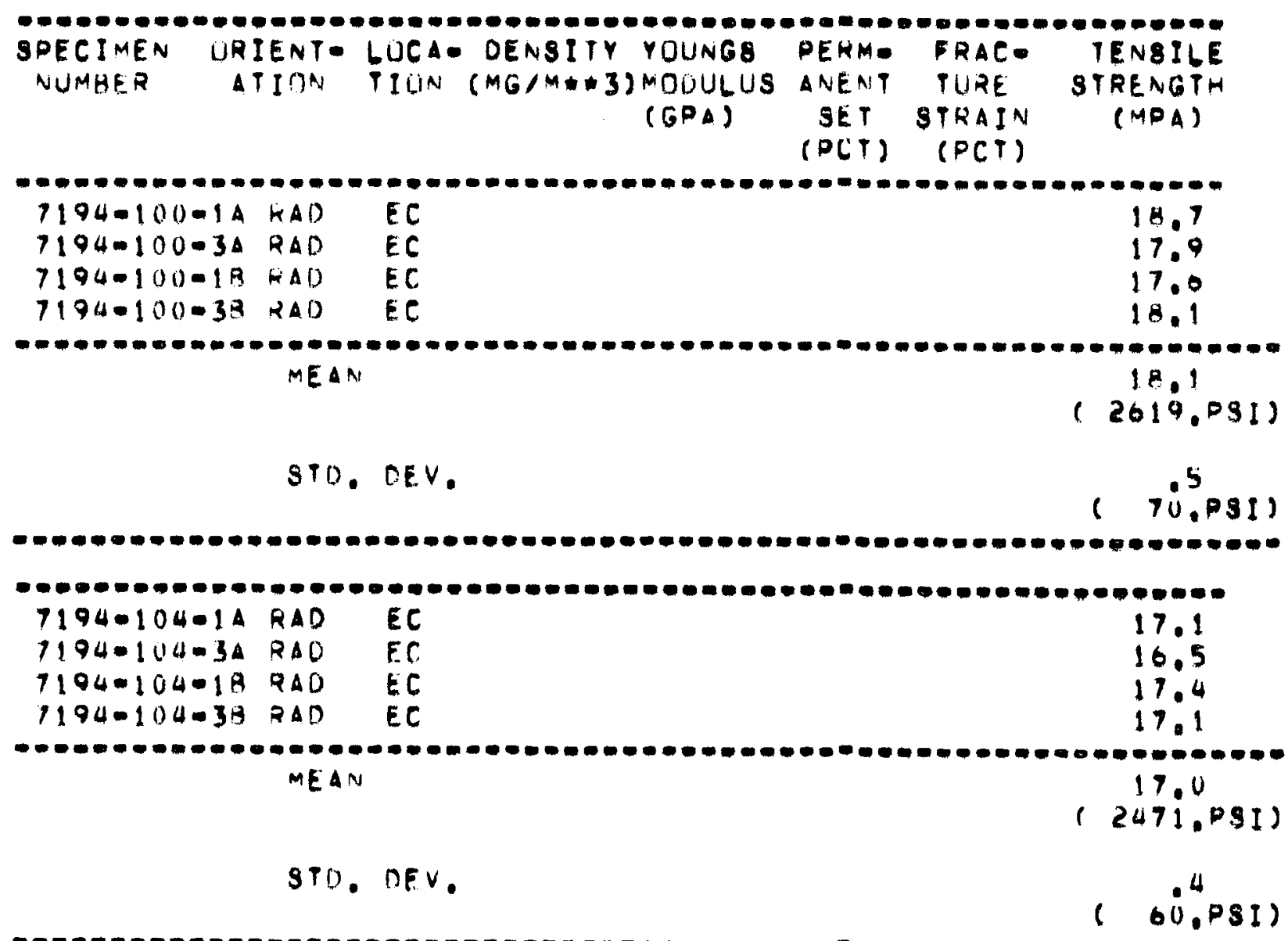

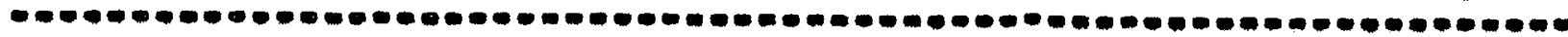

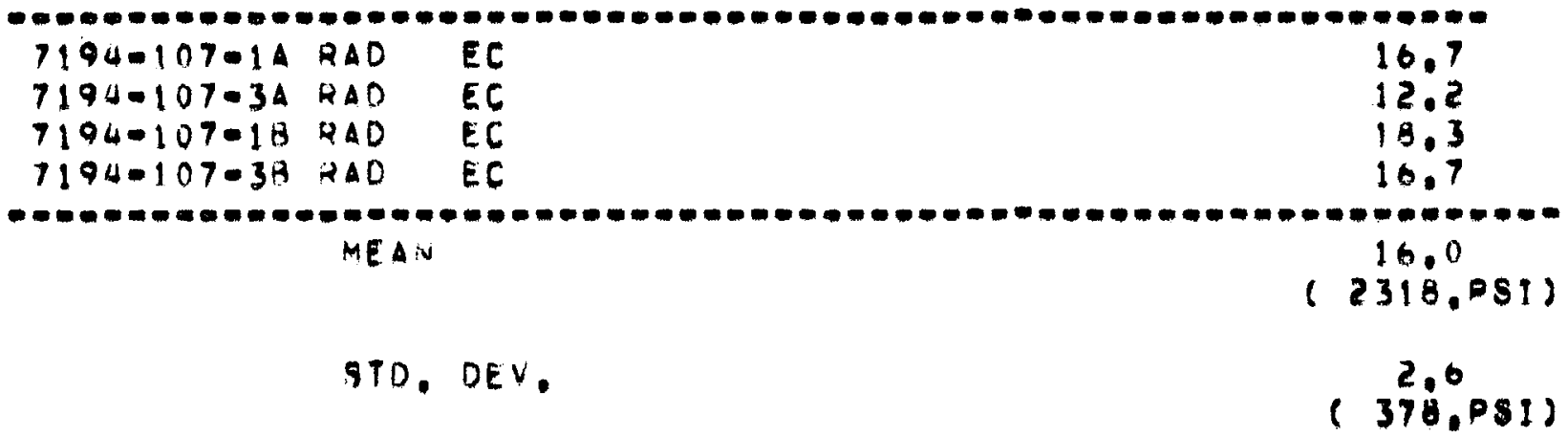

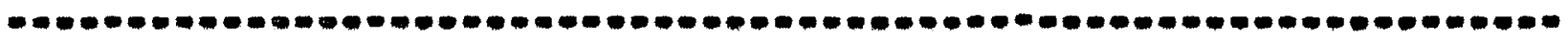

\begin{tabular}{|c|c|c|c|}
\hline $\begin{array}{l}7194-10 B=14 \\
7194=10 B=3 A \\
7194=108=1 B \\
7194=108=3 B\end{array}$ & $\begin{array}{l}R A D \\
R \triangle D \\
R A D \\
R A D\end{array}$ & $\begin{array}{l}E C \\
E C \\
E C \\
E C\end{array}$ & $\begin{array}{l}15.5 \\
16.9 \\
17.6 \\
17.6\end{array}$ \\
\hline \multicolumn{4}{|c|}{ 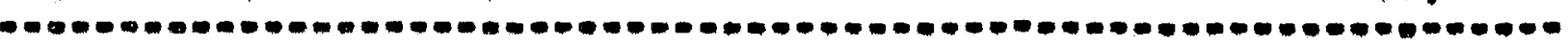 } \\
\hline & MEA & & $\begin{array}{c}16.6 \\
(2440 . P S I)\end{array}$ \\
\hline & STD & DEV. & $(153.091)$ \\
\hline
\end{tabular}


TABLE $C-3$

RADIAL TENSILE STRENGTH MEASUREMENTS: EXTRUSION LOT 482

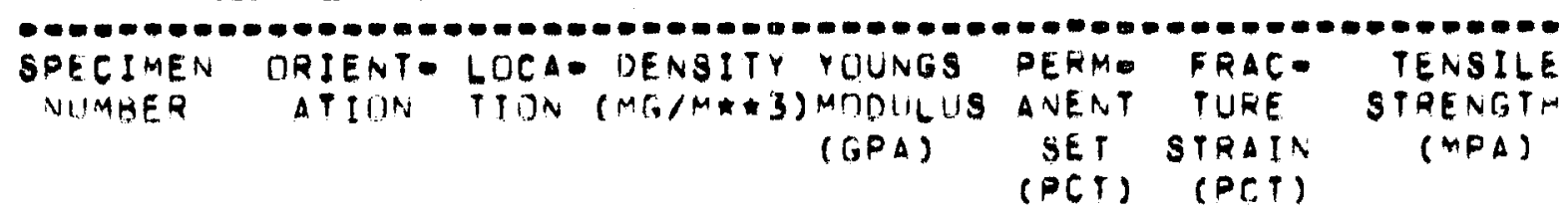

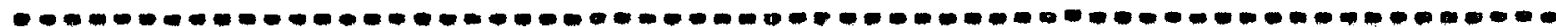
$1194 \cdot 11-14$ RAD
$E C$
9.5
$1994-11-3 A$ RAD
EC
$7194-11.1 B$ RAQ E.
$7194 \cdot 11 \cdot 33$ PAO EC
11.9
12.3
12,6

$0-000-0-0.0-0000$
$M E A N$

11.6

$(10.5 .051)$

STU. OEV.

1.4

(204.PSI)

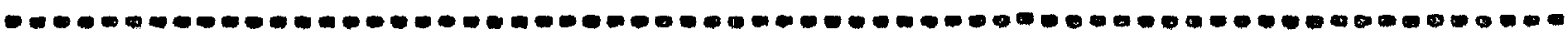

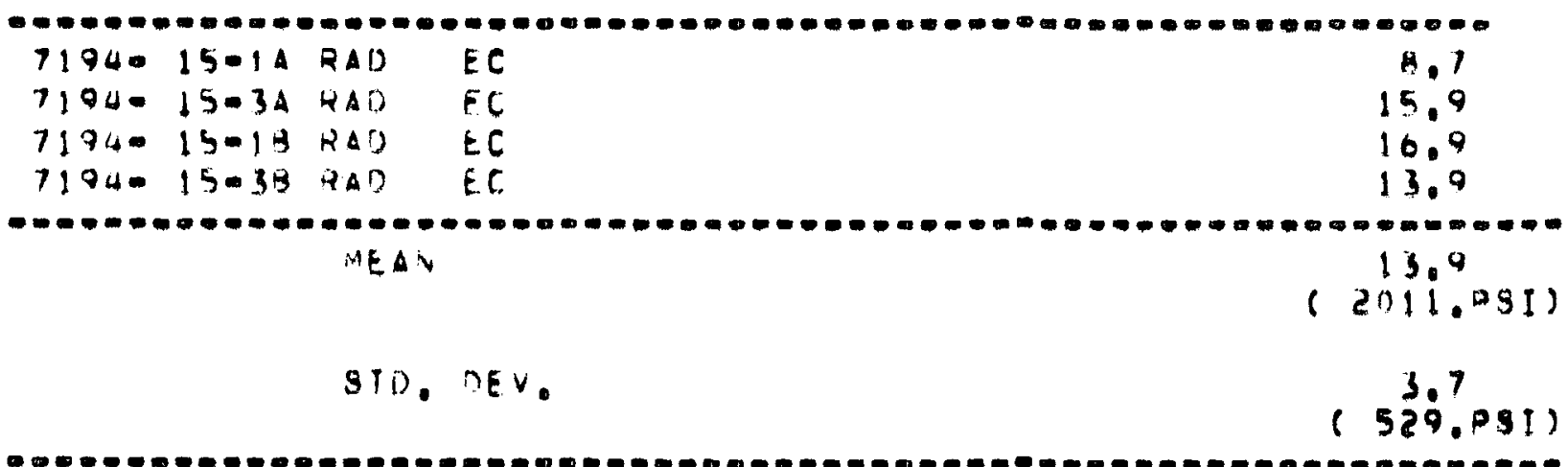

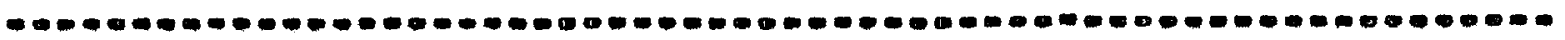

\begin{tabular}{|c|c|c|c|c|}
\hline $\begin{array}{l}71940 \\
71940 \\
11940 \\
71940\end{array}$ & $\begin{array}{l}21-14 \\
21-3 A \\
21-18 \\
21-3 B\end{array}$ & $\begin{array}{l}\text { RAD } \\
\text { RAD } \\
\text { RAD } \\
\text { RAD }\end{array}$ & $\begin{array}{l}E C \\
E C \\
E C \\
E C\end{array}$ & $\begin{array}{l}10.0 \\
15.3 \\
16.8 \\
13.5\end{array}$ \\
\hline
\end{tabular}

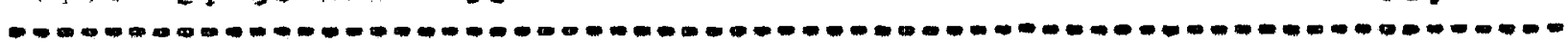

MEA is

15.6

(2265.DSI)

STO. OEV.

$\left(229^{\circ}, 09 !\right)$

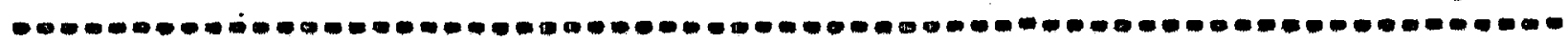

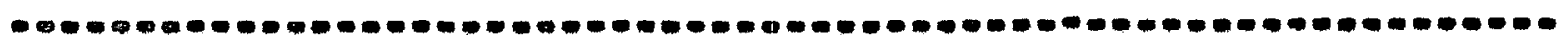

$7194-2201 A$ RAD EC

$7194-22.34$ RAD EC 17.3

$7194=22=18$ RAD EC $\quad 17.5$

$7194-22-3 B$ RAD EC 15.6

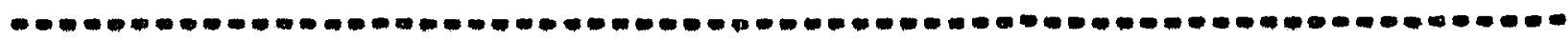
PLAN

17.0

(2465.PSI)

STD. DEV.

( 133.991$)$

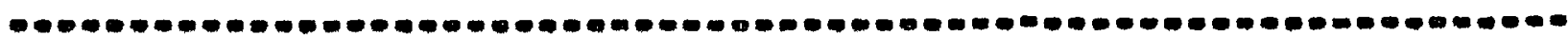




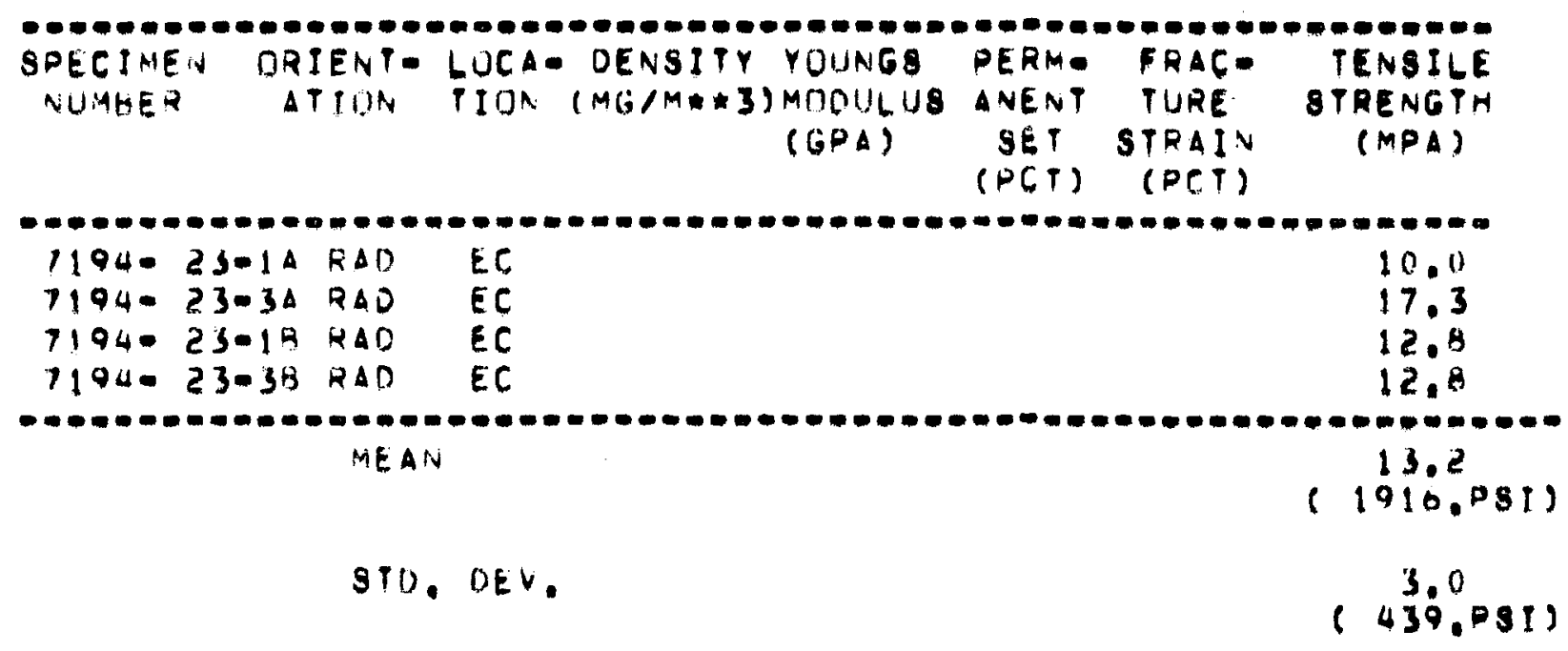

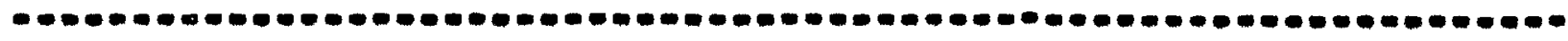

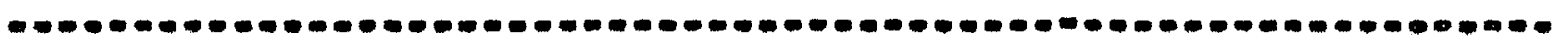

$7194 \cdot 25-14$ RAD EC

$1194.25=34$ RAD EC

$7194-25=19$ RAD EC

$7194=25 \cdot 3 B \times A D \quad E C$

13.8

13.8
12.8

15.6

12.0

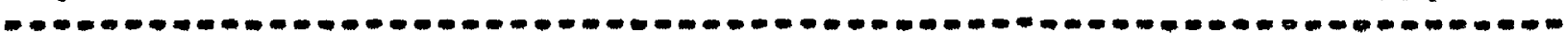

IAEAN

13,5

(1962.091)

STD. WEV.

1.6

$(220.051)$

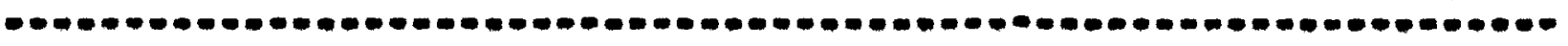

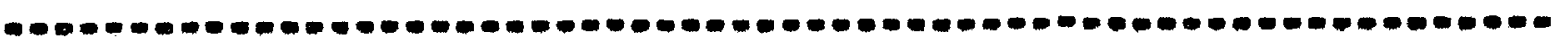

$1194-27-14$ AAD EC $\quad$ E

$7194-27-3 A R A D E C \quad 17.1$

$7194-27-19$ RAD EC

$7194-27-3 B$ RAD EC 17.1

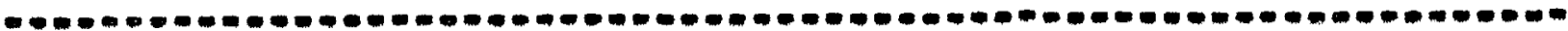

MEN

14.4

(2093.051)

STO. DEV.

3.5

$(510.891)$

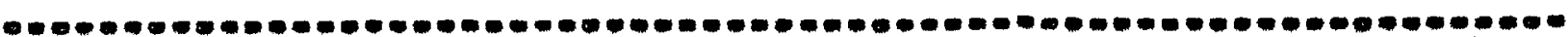

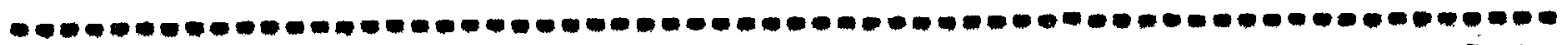
$7194-32-1 A$ RAD EC
$7194-32-34$ RAD EC
$7194=32-1 B$ RAD EC
$7194-32-3 B$ RAO EC
13.1
8. 3
15.3
10.7

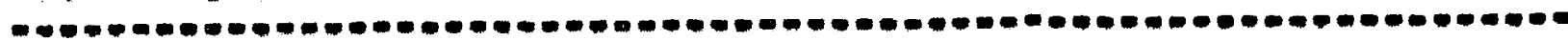
MEAN

11.8

$(1717.91)$

$$
\text { STD. DEV. }
$$

3.0

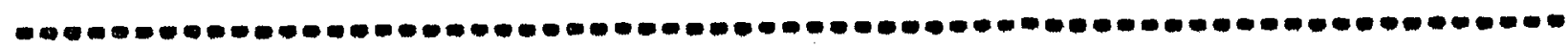




\section{TABLE C-3 (Continued)}

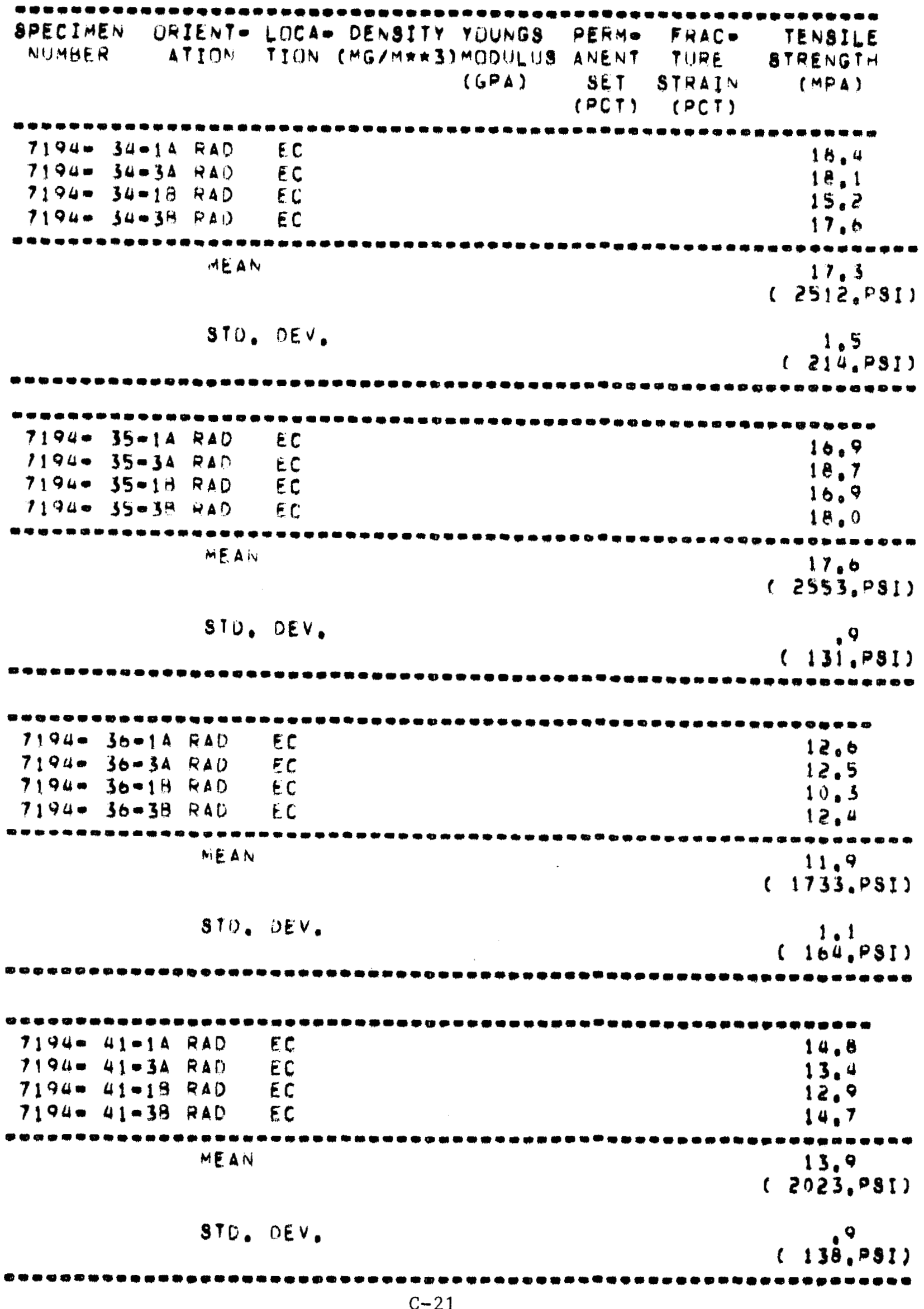


TABLE C-3 (Continued)

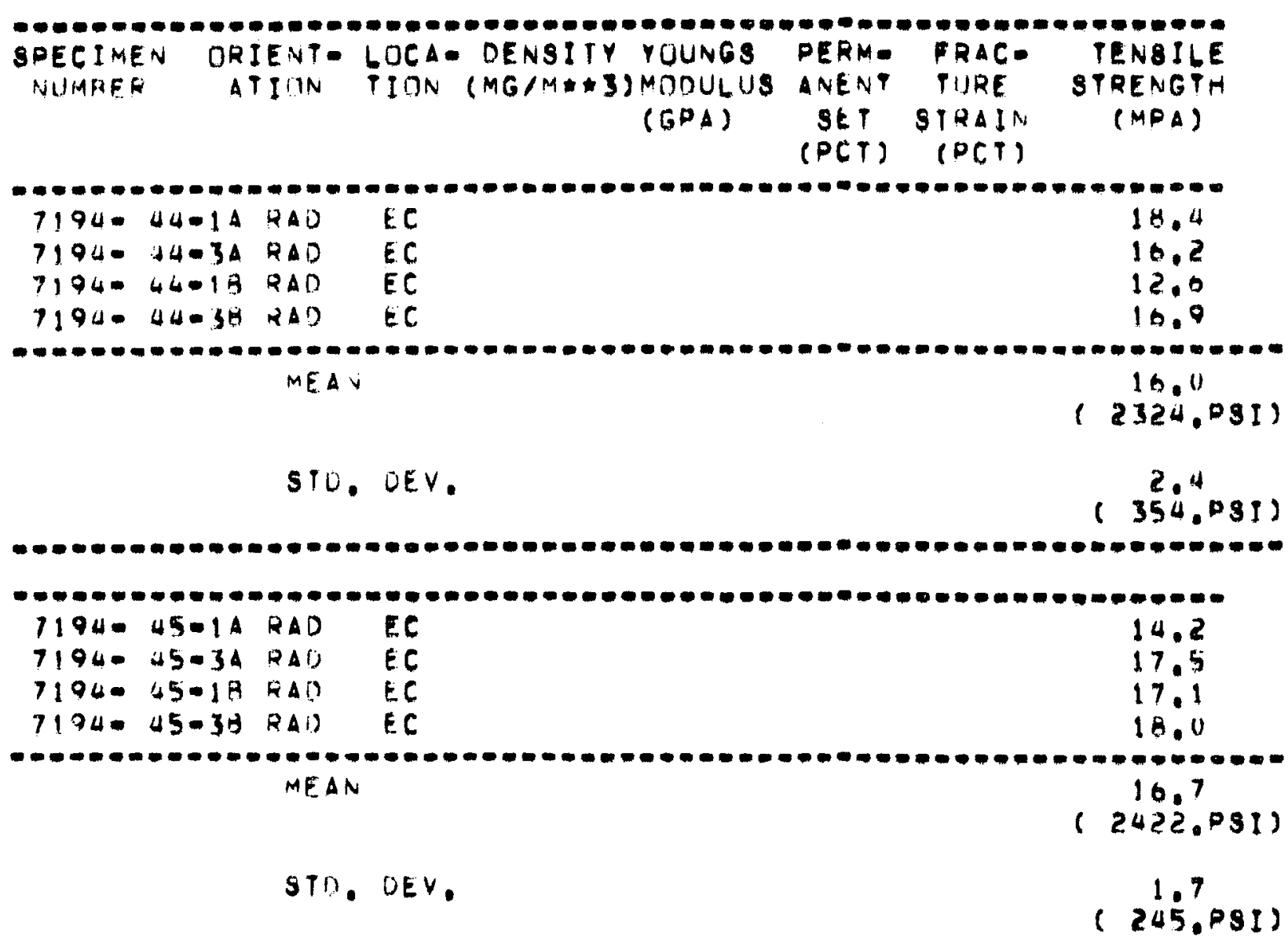

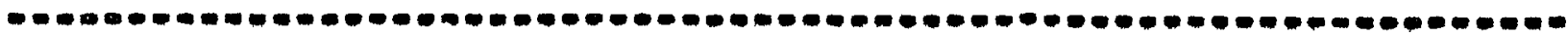

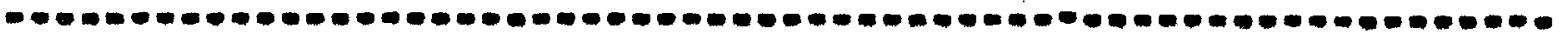

$7194-50-14$ RAD EC 15.1

$7104.50-3 A R A D$ EC $\quad 15.3$

$7194 \cdot 50-19$ RAD EC 16.3

$1194050-3 B$ RAD EC 15.5

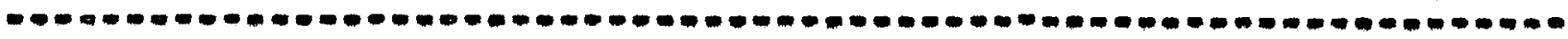
$M E A$

15.5

(2253.P\$1)

STD. DEV.

(. $\left.77^{5} .091\right)$

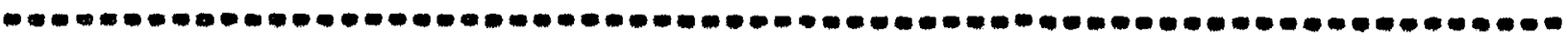

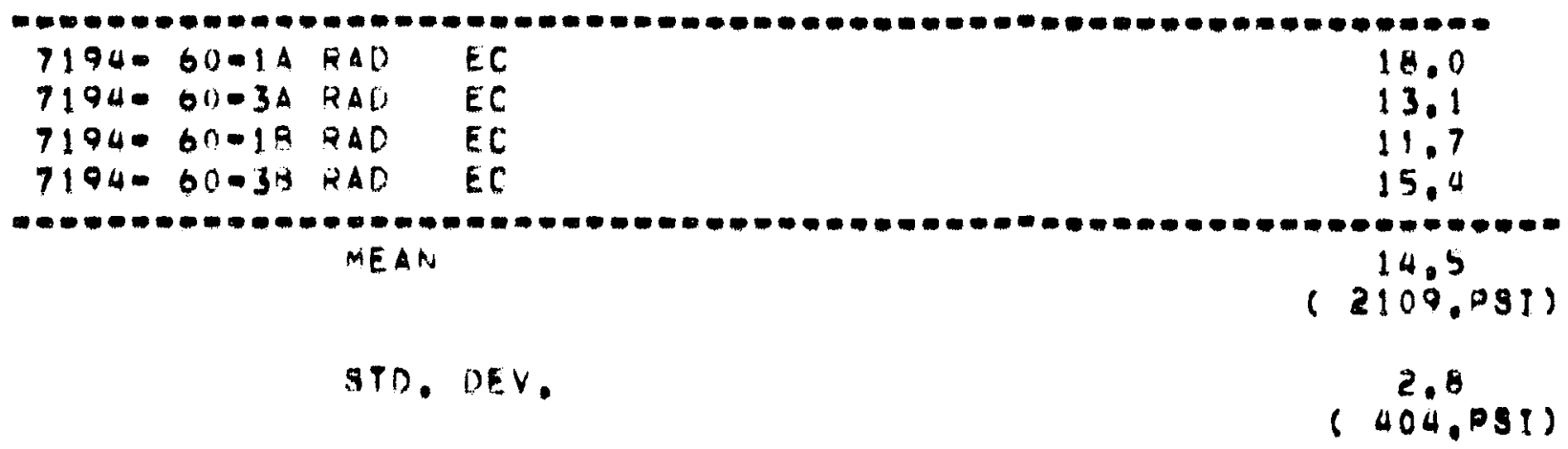

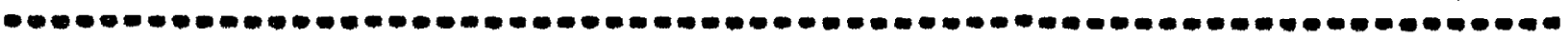




\section{TABLE C-3 (Continued)}

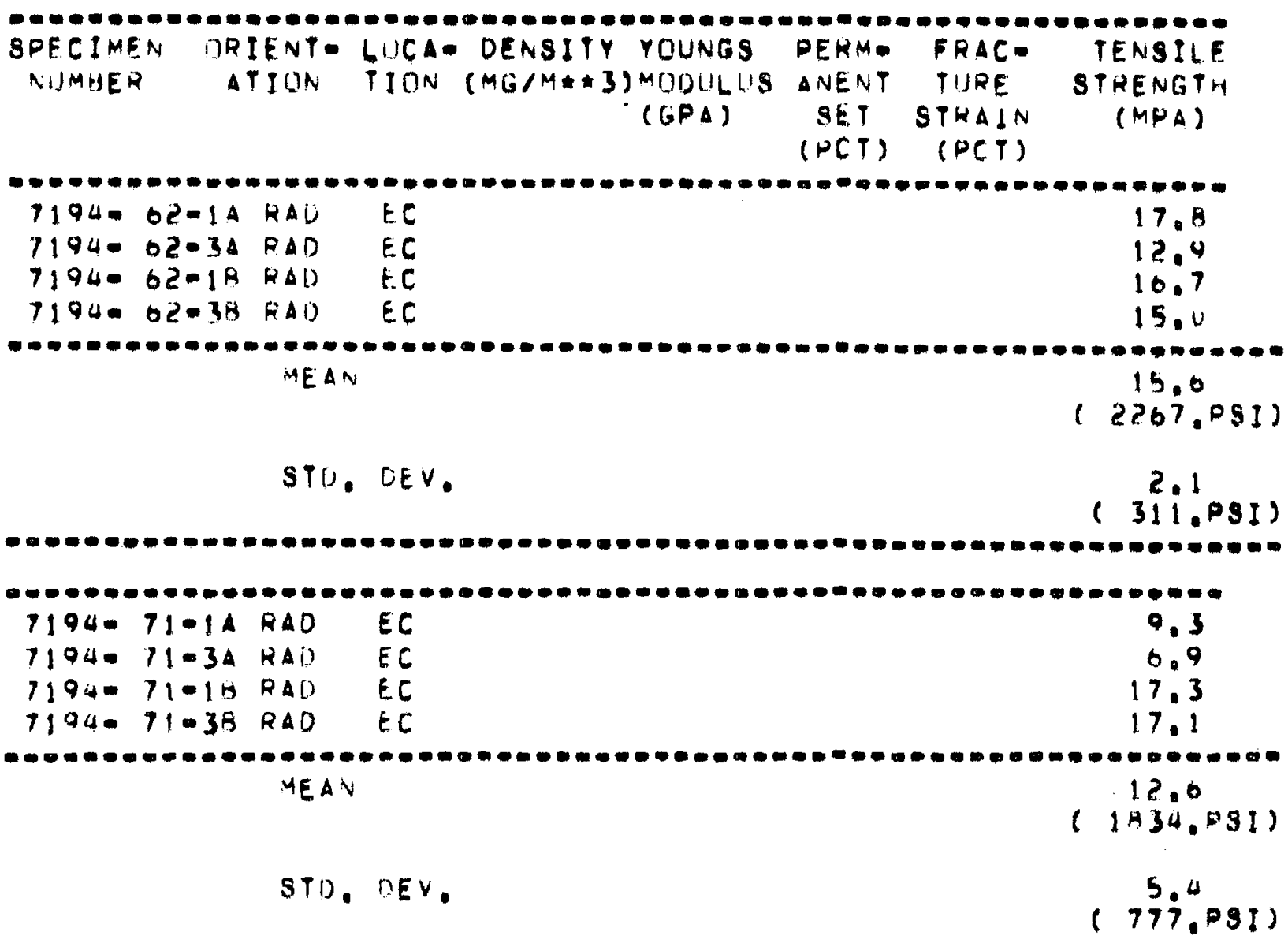

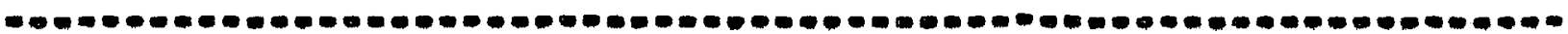

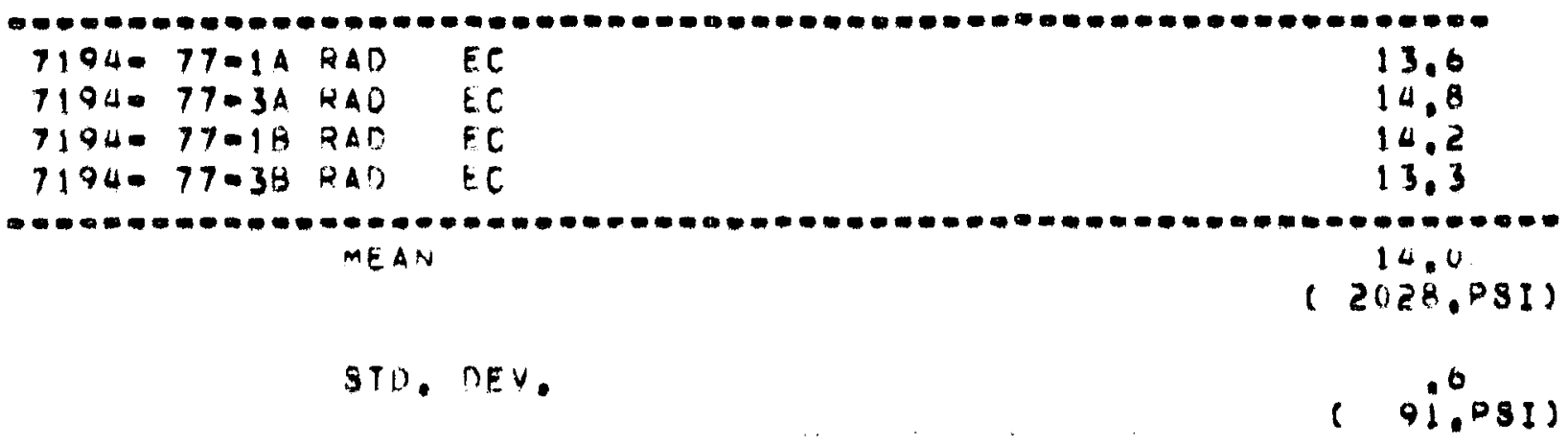

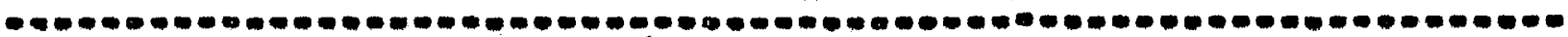

$\begin{array}{ll}1194-81-1 A \text { RAD } E C & 15.9 \\ 7194-B 1-3 A \text { RAD } E C & 14.8 \\ 7194-81-1 B \text { RAD } E C & 13.3 \\ 7194-81-3 B \text { RAD } E C & 16.6\end{array}$

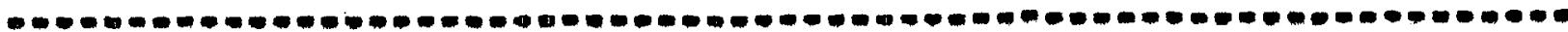

15.1

(2196.PS1)

STO. DEV 


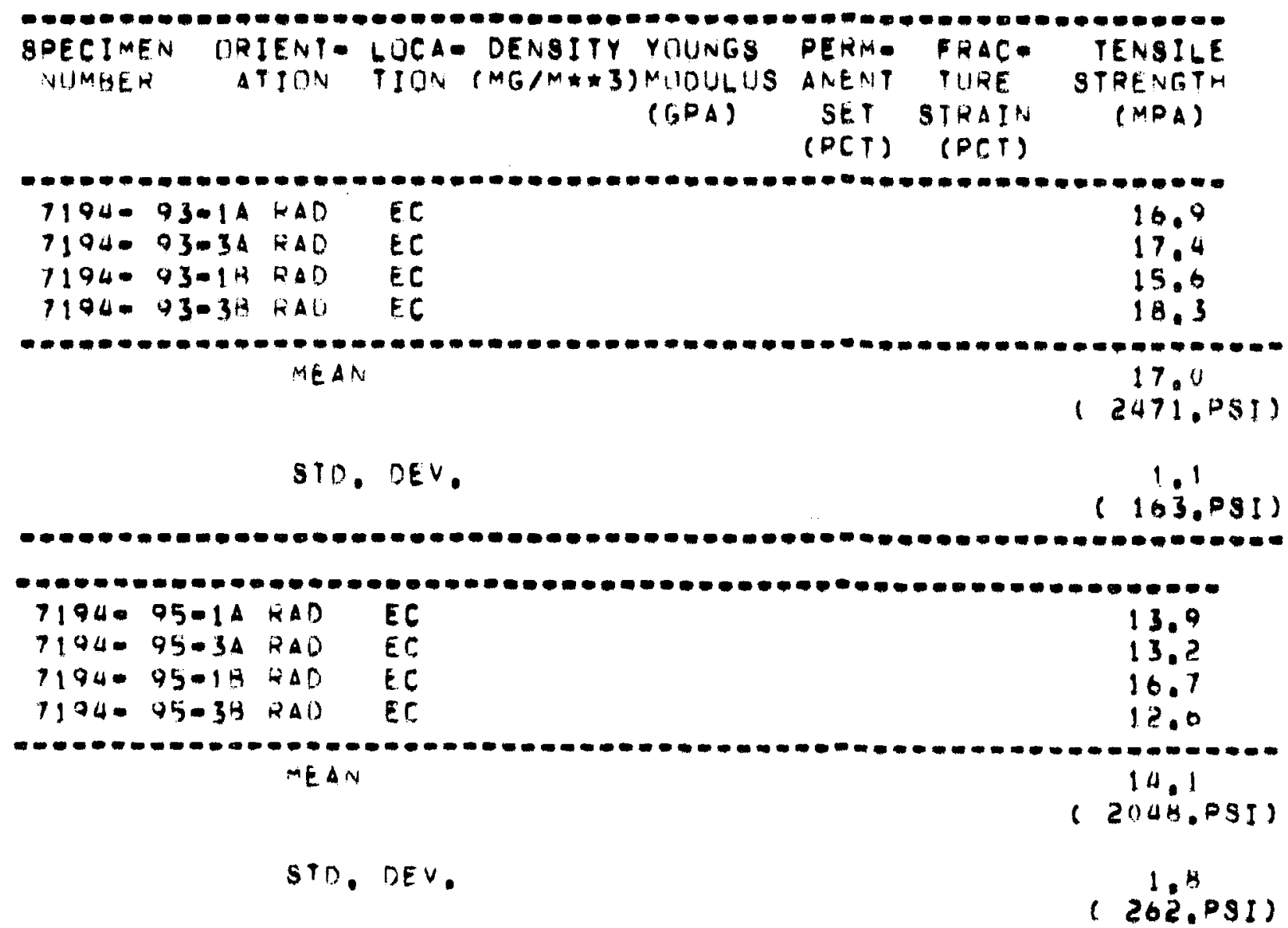

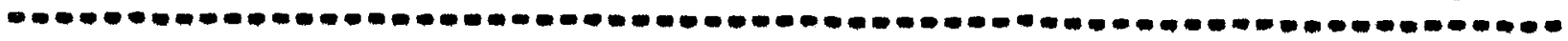

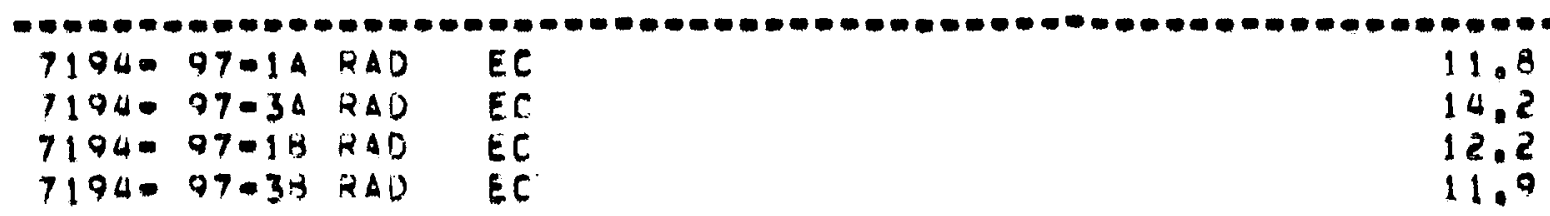

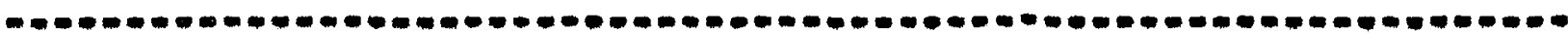
MEA

12.5

$(1819.91)$

STL. DEV.

1.1

$(162 . P S 1)$

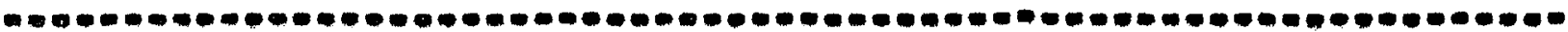

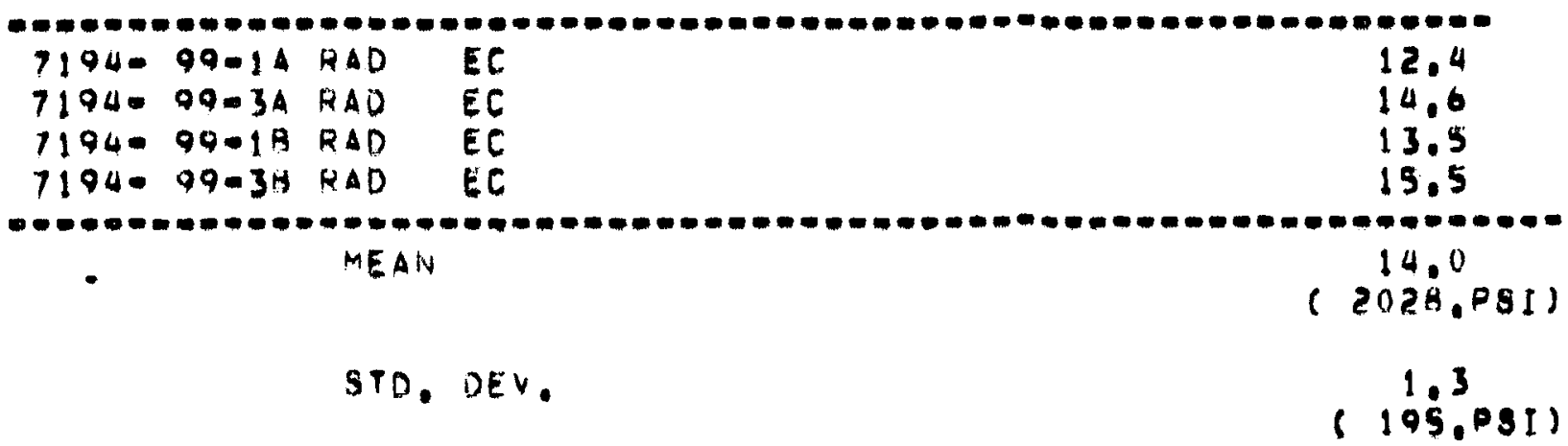

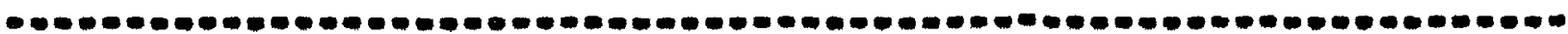




\section{TABLE C-3 (Continued)}

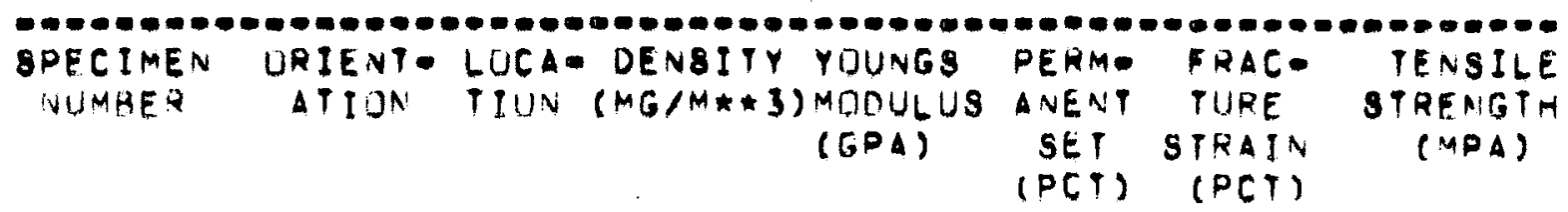

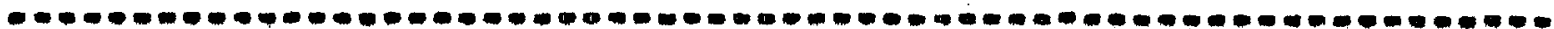

$1104-101-14$ HAO EC

$7194-101-3 A$ RAD EC

$7194-101-1 B$ RAD EC

15.9

$7194-1 U 1-3 A$ RAO EC

8.4

12.5

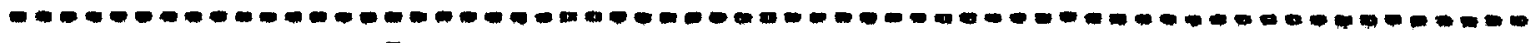
MEAN

11.5

( 1671.51$)$

STD. OEV.

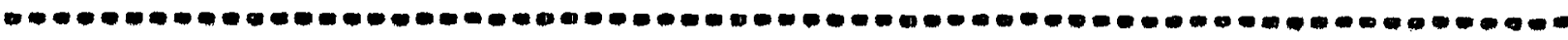

\begin{tabular}{|c|c|c|c|}
\hline $7194-102-14$ & $R \triangle D$ & $E C$ & 12.5 \\
\hline $7194-102-34$ & $2 \Delta 0$ & $E C$ & 14.6 \\
\hline $7194-102-38$ & PAO & EC & 12.5 \\
\hline
\end{tabular}

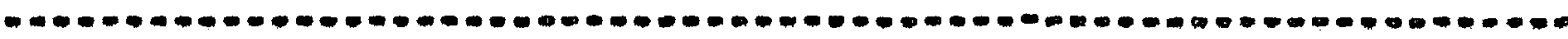
MEA IN

13.5

(1957.091)

STD. DEV.

1.1

$(160.091)$

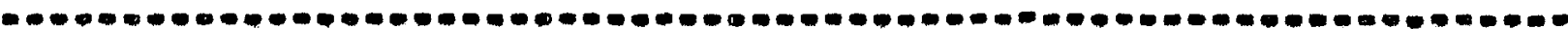

\begin{tabular}{|c|c|c|c|}
\hline $\begin{array}{l}7194=103-1 A \\
7194=103-3 A \\
7194=103-1 B \\
7194-103-3 B\end{array}$ & $\begin{array}{l}R A D \\
R \triangle O \\
R \triangle D \\
R \triangle D\end{array}$ & $\begin{array}{l}E C \\
E C \\
E C \\
E C\end{array}$ & $\begin{array}{r}17.3 \\
B .1 \\
16.6 \\
14.2\end{array}$ \\
\hline \multicolumn{4}{|c|}{ 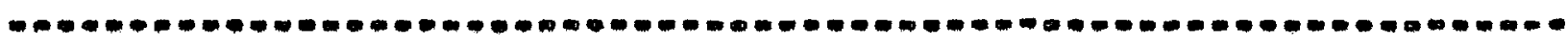 } \\
\hline & ME & & $(2035$ \\
\hline
\end{tabular}

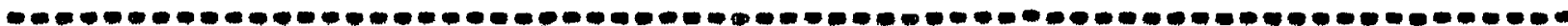

$0000000000000000-00000000000000000000000000000000000000000$

$\begin{array}{llll}7194-106-1 A & R A D & \text { EC } & 17.3 \\ 7194-106-3 A \text { RAD } & \text { EC } & 16.2 \\ 7194-106-1 B \text { HAD } & \text { EC } & 16.7 \\ 7194-106-3 B \text { RAD } & \text { EC } & 15.9\end{array}$

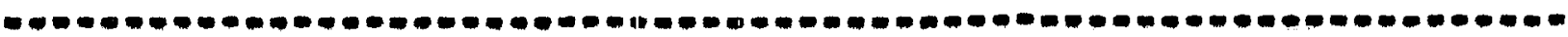
MAN

10.5

(2395.9.91)

STD. OEV.

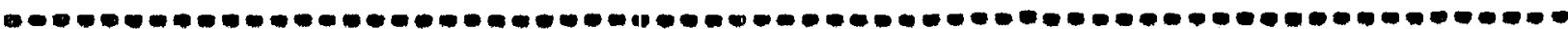


TABLE C-4

SUMMARY OF RADIAL STRENGTH DATA FOR EXTRUSION LOT 472

\begin{tabular}{c|c|c|c}
\hline $\begin{array}{c}\text { GA Log Number } \\
(7194-)\end{array}$ & $\begin{array}{c}\text { Strength } \\
\text { (Mean of Specimens) } \\
(\mathrm{MPa})\end{array}$ & $\begin{array}{c}\text { GA Log Number } \\
(7194-)\end{array}$ & $\begin{array}{c}\text { Strength } \\
\text { (Mean of } 4 \text { Specimens) } \\
(\mathrm{MPa})\end{array}$ \\
\hline 16 & 16.5 & 55 & 16.3 \\
20 & 17.1 & 75 & 16.5 \\
26 & 17.1 & 78 & 16.1 \\
29 & 15.3 & 84 & 16.0 \\
40 & 15.6 & 94 & 17.4 \\
42 & 16.9 & 96 & 17.0 \\
46 & 16.9 & 105 & 14.9 \\
\hline
\end{tabular}


TABLE C-5

SUMMARY OF RADIAL STIRENGTH DATA FOR EXTRUSION LOT 478

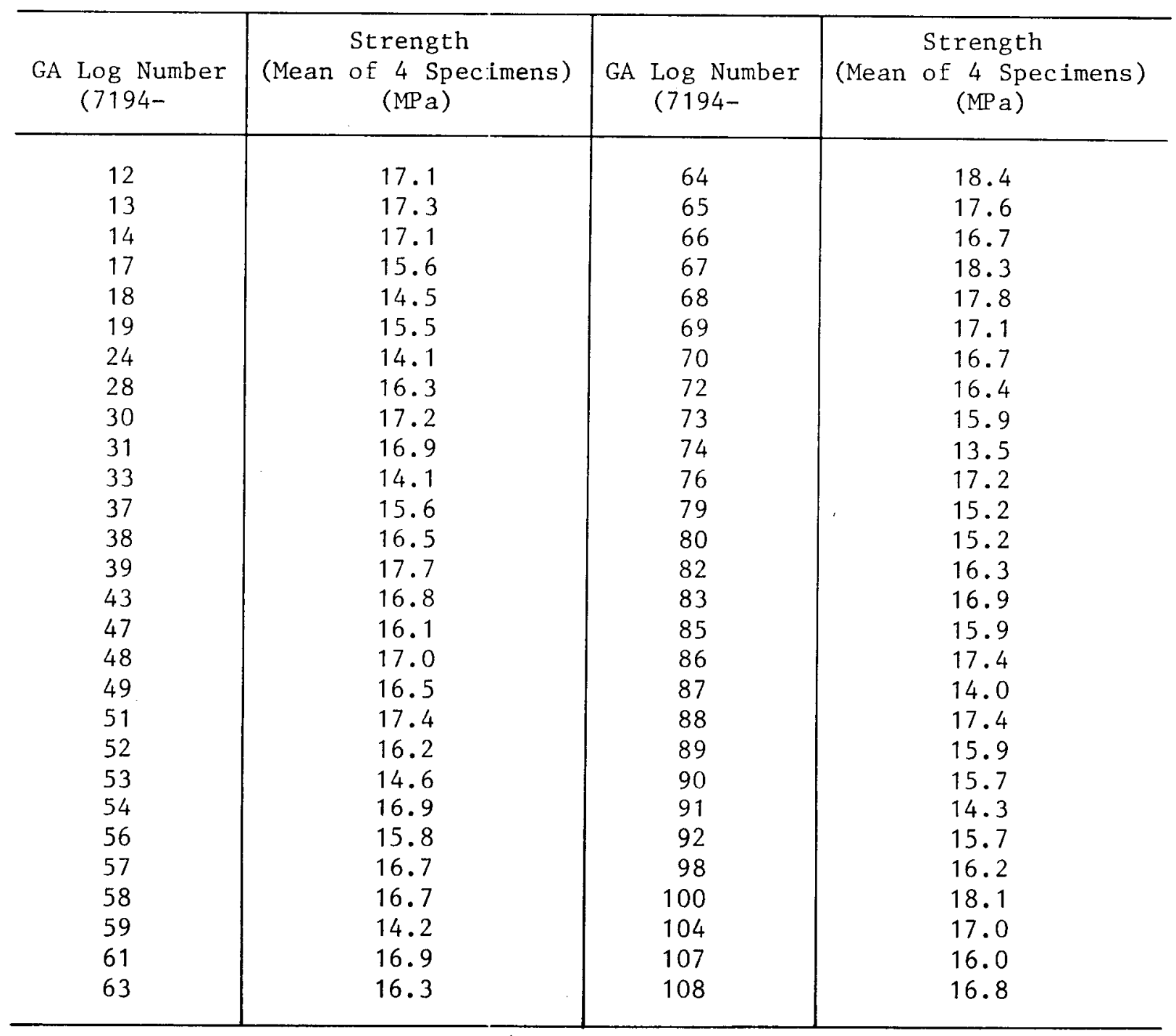


TABLE C-6

SUMMARY OF RADIAL STRENGTH DATA FOR EXTRUSION LOT 482

\begin{tabular}{c|c|c|c}
\hline $\begin{array}{c}\text { GA Log Number } \\
(7194-\end{array}$ & $\begin{array}{c}\text { Strength } \\
\text { (Mean } \begin{array}{c}\text { S Specimens) } \\
(\mathrm{MPa})\end{array}\end{array}$ & $\begin{array}{c}\text { GA Log Number } \\
(7194-\end{array}$ & $\begin{array}{c}\text { Strength } \\
\text { (Mean } 4 \text { Specimens) } \\
(\mathrm{MPa})\end{array}$ \\
\hline & 11.6 & 50 & 15.5 \\
15 & 13.9 & 60 & 14.5 \\
21 & 15.6 & 62 & 15.6 \\
22 & 17.0 & 71 & 12.6 \\
23 & 13.2 & 77 & 14.0 \\
25 & 13.5 & 81 & 15.1 \\
27 & 14.4 & 93 & 17.0 \\
32 & 11.8 & 95 & 14.1 \\
34 & 17.3 & 97 & 12.5 \\
35 & 17.6 & 99 & 14.0 \\
36 & 11.9 & 101 & 11.5 \\
41 & 13.9 & 102 & 13.5 \\
44 & 16.0 & 106 & 14.0 \\
45 & 16.7 & & 16.5 \\
\hline
\end{tabular}

